BASCUÑÁN, Antonio. "Posesión, uso y explotación de la información privilegiada como elementos del insider trading en el derecho comparado del mercado de valores".

Polít. crim. Vol. 12, № 23 (Julio 2017), Art. 13, pp. 453-532.

[http://www.politicacriminal.cl/Vol_12/n_23/Vol12N23A13.pdf]

\title{
Posesión, uso y explotación de la información privilegiada como elementos del insider trading en el derecho comparado del mercado de valores
}

\section{Possession, use and exploitation of insider information as elements of insider trading in the comparative law of the securities market}

\author{
Antonio Bascuñán Rodríguez \\ Abogado - Universidad de Chile \\ Profesor de Derecho Penal \\ Facultad de Derecho Universidad Adolfo Ibáñez, Universidad de Chile \\ a.bascunan@uai.cl
}

\section{Resumen}

El artículo ofrece un examen de derecho comparado relativo a la formulación de la prohibición de operar con información privilegiada en el mercado de valores, atendiendo a si esa prohibición supone la explotación de la información, su simple uso o su mera posesión. En relación con esa cuestión se examina el estatus legal de la orden de operar impartida con anterioridad a la posesión de información privilegiada. Las regulaciones examinadas son el derecho federal estadounidense, el derecho común europeo y el derecho de algunos Estados parte de la Unión Europea, especialmente el derecho español, al 16 de abril de 2014. El artículo sostiene que la formulación de la prohibición que mejor expresa la concepción del insider trading como atentado a la (confianza en) la integridad del mercado es la que considera como elemento de la infracción o delito el uso de la información. La prohibición de operar en posesión de la información es sobreinclusiva respecto del fin de protección y requiere ser complementada con el reconocimiento de excepciones que ponen de manifiesto la relevancia del uso como elemento de la infracción.

Palabras clave: insider trading, insider non trading, operación en posesión de información privilegiada, operación en uso de información privilegiada, cancelación de operación, defensa de la orden previa

\begin{abstract}
The article provides an examination of comparative law concerning the formulation of the ban on insider trading in the stock market, according to whether the ban presupposes the exploitation or advantage taking of the information, or its simply use or mere possession. Relating to that problem is examined the legal status of the order to operate given before the possession of inside information. The regulations examined are those of US federal law, the European common law and the law of some states of the European Union, especially the Spanish law, up to April 16, 2014. The article argues that the wording of the prohibition that best expresses the concept of insider trading as an attack on the (confidence in) the integrity of the market is that which considers the use of the information as an element of
\end{abstract}


BASCUÑÁN, Antonio. "Posesión, uso y explotación de la información privilegiada como elementos del insider trading en el derecho comparado del mercado de valores".

the offense or crime. The prohibition of operating in possession of the information is overinclusive regarding its goal and needs to be complemented with the recognition of exceptions that demonstrate the relevance of use as an element of the offense.

Key words: insider trading, insider non trading, transaction in possession of insider information, transaction in use of insider information, cancellation of orders, previous order defense

Abreviaturas utilizadas

AMF

BGEH

DAM.

DIT

CJA-1993...........

CMF.

COB

CP-E

CP-S

ECJ

ECHR

FCA

FSA

FSMA

ITSA

LMV-E

MAR 1

PO.

POP

POU

$\mathrm{R}$

RAM

RGAMF

SEA
Autorité des Marchés Financiers (Autoridad de los Mercados Financieros), de Francia

Bundesgesetz über die Börsen und den Effektenhandel, Börsengesetz (Ley F€ las Bolsas y el Comercio de Valores, Ley de Bolsas), de Suiza

"Directiva de Abuso de Mercado" (Directiva 2003/6/CE del Parlamento Europeo y del Consejo, de 28 de enero de 2003), en inglés "MAD"

"Directiva de Insider Trading" (Directiva 89/592/CEE, del Consejo, de 13 de noviembre de 1989)

Criminal Justice Act (Ley de Justicia Criminal) de 1993, del Reino Unido

Code Monétaire et Financier (Código Monetario y Financiero), de Francia

Commission des Opérations de Bourse (Comisión de Operaciones de Bolsa), de Francia

Código Penal de España

Código Penal de Suiza (sin otra especificación, el vigente entre 1988 y 2012)

European Court of Justice (Tribunal de Justicia Europeo)

European Court of Human Rights (Tribunal Europeo de Derechos Humanos)

Finantial Conduct Authority (Autoridad de la Conducta Financiera), del Reino Unido

Finantial Service Authority (Autoridad del Servicio Financiero), del Reino Unido

Financial Services and Markets Act (Ley de Servicios Financieros y Mercados), del Reino Unido

Insider Trading Sanctions Act (Ley de sanciones al insider trading), de los Estados Unidos

Ley de Mercado de Valores de España

Code of Market Conduct (Código de Conducta del Mercado), del Reino Unido

Prohibición de operar con información privilegiada, en el sentido señalado en la sección 2

Prohibición de operar en posesión de información privilegiada, en el sentido señalado en la sección 2

Prohibición de operar en uso de información privilegiada, en el sentido señalado en la sección 2

"Regla" (disposición establecida por la SEC conforme a la SEA)

"Reglamento de abuso de Mercado" (Reglamento (UE) 596/2014 del Parlamento Europeo y el Consejo, de 16 de abril de 2014), en inglés "MAR"

Règlement Général de l'Autorité des Marchés Financiers (Reglamento General de la Autoridad de Mercados Financieros), de Francia

Securities Exchange Act (Ley [federal] de Mercado de Valores de los Estados Unidos) 
Polít. crim. Vol. 12, № 23 (Julio 2017), Art. 13, pp. 453-532.

[http://www.politicacriminal.cl/Vol_12/n_23/Vol12N23A13.pdf]

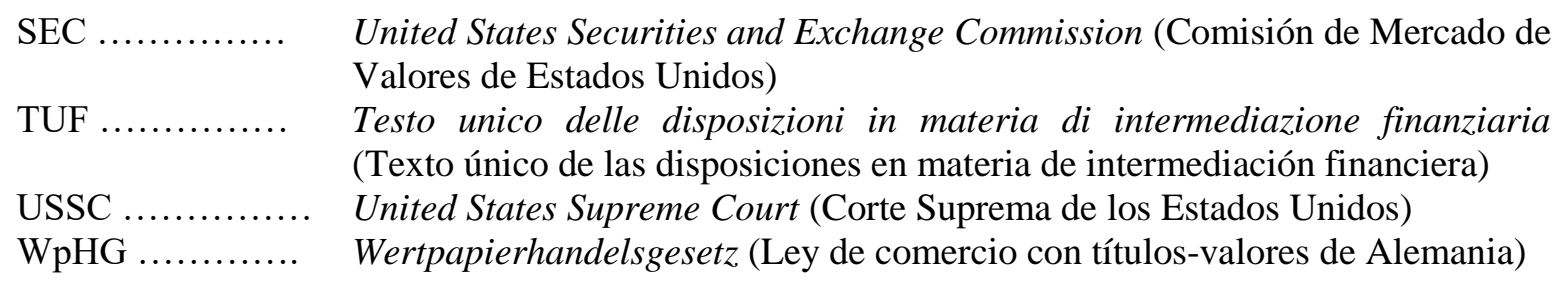

\section{Introducción $^{1}$}

Desde el surgimiento en el año $2007^{2}$ de su doctrina acerca del deber de abstención establecido en el inciso primero del art. 165 de la Ley 18045 la Superintendencia de Valores y Seguros ("SVS") afirma que dicha ley impone al que entra en posesión de información privilegiada el deber de cancelar toda orden de efectuar operaciones en el mercado de valores por cuenta suya que se encuentre pendiente de ejecución, aun cuando haya impartido la orden antes de poseer esa información. Según su doctrina, el poseedor de información privilegiada que omite cancelar la orden infringe negligentemente el deber de abstención.

El objetivo de este artículo es mostrar que esa doctrina contradice doblemente principios regulativos del insider trading ${ }^{3}$ extendidos en el derecho comparado. La doctrina de la SVS es inconsistente con el derecho comparado, primero, porque no reconoce la excepción o defensa de la orden previa. Conforme a esta defensa o excepción quien imparte una orden de operar sin poseer información privilegiada no incurre en infracción a la prohibición de operar con información privilegiada si se limita a dejar que el intermediario la ejecute en los mismos términos con que la impartió. En segundo lugar la doctrina de la SVS es inconsistente con el derecho comparado porque no advierte que la cancelación de la orden

\footnotetext{
${ }^{1}$ Este artículo corresponde a la primera parte de un estudio que fue elaborado como apoyo a un informe en derecho encargado por la defensa jurídica del inversionista sancionado por la Superintendencia de Valores y Seguros en su Resolución Exenta $\mathrm{N}^{\circ} 338$, de 25 de noviembre de 2015, rectificada por Resolución Exenta $\mathrm{N}^{\circ}$ 339, de la misma fecha. El informe en derecho lleva por título "El estatus de operaciones realizadas en ejecución de una orden previa a la posesión de información privilegiada en la Ley 18.045 sobre mercado de valores", consta de 111 páginas y adopta la forma de respuestas binarias (sí/no) fundadas a 26 cuestiones jurídicas relacionadas con la materia. La segunda parte del estudio corresponde a un examen del derecho chileno del mercado de valores que será publicada posteriormente en esta Revista.

${ }^{2}$ Resoluciones Exentas de la SVS N 306 y 307, de 6 de junio.

${ }^{3}$ Por insider trading o insider dealing (esta última es la denominación inglesa) se entiende, en sentido stricto, la operación en el mercado de valores (trading/dealing) que hace aquél que posee información privilegiada en razón de una calidad personal especial (insider). En sentido amplio, el trading/dealing cubre no sólo la operación en el mercado de valores, sino la revelación de la información privilegiada y la recomendación de operar; a partir del año 2014, en el derecho común europeo también quedan cubiertas por el concepto la operación realizada por el destinatario de la recomendación, la revelación de la recomendación y la cancelación o modificación de órdenes de operar. Asimismo, en sentido amplio el insider abarca no sólo al que tiene una calidad personal especial, sino a todo poseedor de información privilegiada. Para efectos de este artículo no es relevante la cuestión de quién sea insider: como hipótesis de trabajo se asume que el análisis siempre se refiere a un destinatario idóneo de la prohibición de insider trading según la regulación aplicable; tampoco interesa mayormente la calificación como trading de la revelación o recomendación. Por el contrario, la calificación de la cancelación o modificación de la orden como trading o non trading es uno de sus objetos principales de examen.
} 
BASCUÑÁN, Antonio. "Posesión, uso y explotación de la información privilegiada como elementos del insider trading en el derecho comparado del mercado de valores".

en base a la información poseída constituye un atentado a la integridad del mercado de valores equiparable a la operación realizada en uso de esa información. En otras palabras, la doctrina de la SVS priva injustamente de beneficio económico al que acertó sujetándose a las mismas condiciones que los demás inversionistas y al que erró le evita injustamente la pérdida económica que según las reglas comunes tendría que soportar. Es una doctrina absurda.

La crítica detallada de la doctrina de la SVS no es materia de este artículo, sino de otro que seguirá en esta misma revista. El objetivo de este artículo es examinar el estatus en el derecho comparado de la orden previa a la posesión de información privilegiada y su cancelación posterior. Antes de proceder a la descripción de los distintos sistemas jurídicos extranjeros es conveniente despejar mediante el análisis conceptual lo que podría considerarse como la aproximación intuitiva a la calificación jurídica de la mantención y la cancelación de una orden de operar en el mercado de valores. Esa aproximación intuitiva genera un malentendido que se advierte recurrentemente en la doctrina comparada, particularmente en la española, y que también subyace a la doctrina de la SVS.

El punto de partida del análisis de la mantención y la cancelación o modificación de una orden de operar en el mercado de valores es que la ejecución de la orden implica por definición normativa una doble operación: (i) quien recibe la orden, usualmente un intermediario, opera directamente en interés ajeno cuando la ejecuta, y (ii) quien imparte la orden, esto es, el inversionista, opera indirectamente en interés propio cuando ella es ejecutada por otro. El mandato en que la orden consiste genera esta doble estructura de imputación de realización simultánea de una operación: directa por cuenta de otro e indirecta por cuenta propia. A esta premisa se suma otra definición normativa, consistente en que la omisión de operar en el mercado de valores es jurídicamente irrelevante, incluso si esa omisión se explica como una decisión basada en información privilegiada. Este es el principio de la irrelevancia jurídica del insider non trading: quien habiendo meramente adoptado una decisión de operar entra en posesión de información privilegiada inconsistente con esa decisión y por esa razón desiste de su propósito no infringe norma alguna de comportamiento relativa al insider trading.

Partiendo de estas premisas la aproximación intuitiva identifica una diferencia elemental entre operar (realizar una operación) y omitir operar (abstenerse de realizar una operación). Esta diferencia es esencial para las normas del derecho comparado sobre insider trading, que prohíben realizar una operación con información privilegiada y no prohíben abstenerse de realizarla. La aproximación intuitiva es consistente con la estructura de doble imputación implicada por la orden: quien imparte una orden realiza una operación indirectamente cuando ella es ejecutada por otro. Luego, impartir la orden y mantenerla vigente hasta su ejecución son en conjunto acciones intuitivamente equiparables a realizar la operación de propia mano. Inversamente, quien cancela una operación impide su realización, por lo que se comporta de modo intuitivamente equiparable a quien omite operar (se abstiene de realizar una operación) ${ }^{4}$. Esto puede resumirse en el siguiente cuadro:

\footnotetext{
${ }^{4}$ El concepto de modificación de una orden se deja reconducir a los conceptos de impartir y cancelar una orden de operar: si la modificación consiste en ampliar la operación ordenada, equivale a una nueva orden de operar; si, en cambio, consiste en restringirla, equivale a una cancelación parcial de la orden previa.
} 
Polít. crim. Vol. 12, No 23 (Julio 2017), Art. 13, pp. 453-532.

[http://www.politicacriminal.cl/Vol_12/n_23/Vol12N23A13.pdf]

CUADRO 1: LA APROXIMACIÓN INTUITIVA

\begin{tabular}{|c|c|c|}
\hline & Operar & Ordenar operar \\
\hline Prohibido & Operar (realizar operación) & $\begin{array}{c}\text { Impartir y mantener } \\
\text { una orden }\end{array}$ \\
\hline Permitido (indiferente) & $\begin{array}{c}\text { Omitir operar } \\
\text { (abstenerse de realizar } \\
\text { operación) }\end{array}$ & Cancelar una orden \\
\hline
\end{tabular}

El problema de la aproximación intuitiva es que no toma en consideración la cuestión esencial de la regulación del insider trading, a saber, si las acciones en cuestión son consistentes o inconsistentes con la información privilegiada poseída. Esto implica que la aproximación intuitiva, aunque coherente con la estructura de doble imputación implicada por una orden no es coherente con la racionalidad teleológica y sistemática de la regulación del insider trading.

La manera más efectiva de incorporar esa racionalidad es preguntarse por el fundamento de la irrelevancia jurídica del insider non trading. Más allá de la mera constatación de la imposibilidad lingüística de subsumir la omisión de operar en el supuesto de hecho de la prohibición de operar ${ }^{5}$, el argumento de análisis económico favorable a su autorización se basa en el principio básico de la concepción del insider trading como un atentado de peligro abstracto contra el bien jurídico colectivo de la (confianza en la) integridad del mercado. Como lo ha mostrado Jesse Fried $^{6}$, la auténtica razón para entender que la

\footnotetext{
${ }^{5}$ La omisión de operar no es comisión por omisión de insider trading. La comisión por omisión supone que se realice el supuesto de hecho -o el elemento que corresponde al resultado- y que esa realización no sea evitada; siempre es un omitir evitar un estado de cosas. Tratándose del insider trading, dado que la prohibición de operar configura un delito o infracción de mera actividad y no de resultado, la extensión de la tipicidad a la comisión por omisión en virtud de una posición de garante implicaría responsabilidad por omitir impedir operar a otro (omitir evitar la acción típica de un tercero), y no simplemente por omitir operar (abstención, non trading). Este dato básico no es suficientemente reconocido por la doctrina española (infra, sección 4.3). La omisión de cancelar una orden sí puede ser trivialmente considerada comisión por omisión, en la medida en que operar indirectamente implica trivialmente omitir evitar la operación directa correlativa.

${ }^{6}$ FRIED, Jesse, "Insider Abstention", Yale Law Journal n ${ }^{\circ} 113$ (2003), pp. 455-492, especialmente pp. 466480. Aplicando un modelo simple de análisis de situaciones de compra y venta de acciones de la sociedad de la que se es insider y usando un portfolio representativo del mercado como comparación, Fried examina las situaciones en que al insider: (i) le está permitido operar y abstenerse, (ii) le está prohibido operar y permitido abstenerse y (iii) le está prohibido operar y abstenerse. En el caso (i) el insider se encuentra en ventaja
} 
BASCUÑÁN, Antonio. "Posesión, uso y explotación de la información privilegiada como elementos del insider trading en el derecho comparado del mercado de valores".

abstención de operar basada en información privilegiada no debe ser prohibida se encuentra en el igualitarismo de mercado que inspira esa concepción del insider trading. Si los poseedores de información privilegiada estuvieran obligados a operar de modo inconsistente con la información poseída tal como les está prohibido operar de modo consistente con ella entonces no quedarían situados en igualdad de condiciones al inversionista que no posee información privilegiada, sino en una condición empeorada: todos deberían autoirrogarse un perjuicio patrimonial cada vez que poseyeran información.

Una vez que se aclara la razón de la licitud del insider non trading puede analizarse el estatus de la orden previa a la posesión de información privilegiada y de su cancelación con posterioridad a la entrada en posesión de información privilegiada. Desde el punto de vista de la aproximación intuitiva impartir y mantener una orden equivale a operar (realizar una operación) y cancelar una orden equivale omitir operar (abstenerse de realizar una operación). Pero es obvio que desde el punto de vista de la racionalidad económica y sistémica quien cancela una orden basándose en información privilegiada obtiene una ventaja comparativa respecto del inversionista que no posee esa información y que quien debe cancelar una orden porque su ejecución resulta consistente con la información privilegiada que posee con posterioridad es obligado a autoirrogarse un perjuicio por el hecho de poseer esa información. Por esta razón, el tratamiento de la cancelación de la orden que es congruente con un régimen legal que prohíbe la operar con información privilegiada y autoriza omitir operar con información privilegiada es prohibir la cancelación de la orden en uso de información privilegiada y autorizar la mantención de la orden en posesión de información privilegiada. En palabras de Fried:

"In essence, the regime created when an insider uses irrevocable instructions or a binding contract to enter the safe harbor is the mirror image of Rule 10b-5 [= the prohibition of insider trading according to the SEC]. Rule 10b-5, according to the SEC, does not allow an insider to trade while aware of material nonpublic information but permits the insider to abstain on such information. This safe harbor regime $[=$ the exemption from the prohibition] permits the insider to trade while aware of material nonpublic information (as long as the trade is effected pursuant to irrevocable instructions or a binding agreement) but not permit the insider to abstain from trading by canceling the intended trade. In either case, an insider cannot expect to beat the market using material nonpublic information". 7

El planteamiento puede ser expresado gráficamente en el siguiente cuadro (donde "ip" = información privilegiada).

CUADRO 2: LA COMPRENSIÓN DE FRIED

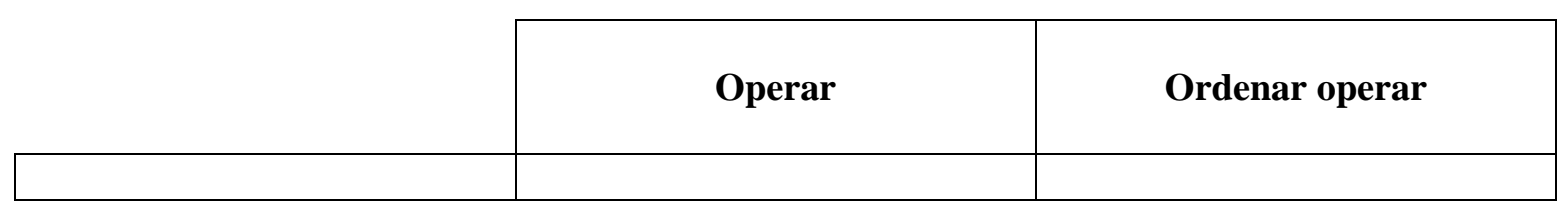

respecto del inversionista que carece de información privilegiada; en el caso (iii), en desventaja. En conclusión, sólo el caso (ii) realiza el postulado del igualitarismo de mercado.

${ }^{7}$ FRIED, "Insider abstention", cit. nota n 6 , p. 89. 
Polít. crim. Vol. 12, № 23 (Julio 2017), Art. 13, pp. 453-532.

[http://www.politicacriminal.cl/Vol_12/n_23/Vol12N23A13.pdf]

\begin{tabular}{|c|c|c|}
\hline $\begin{array}{c}\text { Posición ventajosa del } \\
\text { poseedor de ip } \\
\text { (debe ser prohibida) }\end{array}$ & $\begin{array}{c}\text { Realizar operación consistente } \\
\text { con ip }\end{array}$ & $\begin{array}{c}\text { Impartir una orden de } \\
\text { operación consistente con ip o } \\
\text { cancelar una orden de } \\
\text { operación inconsistente con ip }\end{array}$ \\
\hline $\begin{array}{c}\text { Posición desventajosa del } \\
\text { poseedor del ip } \\
\text { (no debe ser mandada) }\end{array}$ & $\begin{array}{c}\text { Realizar operación } \\
\text { inconsistente con ip }\end{array}$ & $\begin{array}{c}\text { Impartir una orden de } \\
\text { operación inconsistente con ip } \\
\text { o cancelar orden de operación } \\
\text { consistente con ip }\end{array}$ \\
\hline $\begin{array}{c}\text { Posición equitativa del } \\
\text { poseedor de ip } \\
\text { (debe ser permitida si la } \\
\text { posición ventajosa es } \\
\text { prohibida) }\end{array}$ & $\begin{array}{c}\text { Abstenerse de realizar } \\
\text { operación inconsistente } \\
\text { con ip }\end{array}$ & $\begin{array}{c}\text { Mantener orden de operación } \\
\text { consistente con ip }\end{array}$ \\
\hline
\end{tabular}

Como pone de manifiesto el cuadro, la importancia práctica de una correcta comprensión de las relaciones entre los casos posibles de operar y ordenar operar desde un punto de vista teleológico y sistémico no se reduce al reconocimiento de la legitimidad de mantener la orden previa a la posesión de información privilegiada. Tan importante como eso es la advertencia de la ilegitimidad y por lo tanto el merecimiento de sanción de la cancelación de una orden previa con posterioridad a la entrada en posesión de información. Este es el modo como opera un insider sofisticado: imparte la orden antes de entrar en posesión de información concreta, conjeturándola, y luego, si la información no es consistente con la operación ordenada, la cancela. Dado que la prohibición de insider trading supone la realización de una operación, y dado que la cancelación se traduce en la omisión de una operación (insider non trading), la cancelación en uso de información privilegiada queda sin sanción. Como se verá, el derecho comunitario europeo ha enfrentado esta práctica calificando a la cancelación o modificación de órdenes como operaciones con información privilegiada.

Traducidos estos resultados a la tabla anterior, se tiene que las correlaciones consistentes con la racionalidad teleológica y sistémica del mercado de valores son las siguientes:

CUADRO 3: LA COMPRENSIÓN CONFORME A LA RACIONALIDAD TELEOLÓGICA Y SISTÉMICA

\begin{tabular}{|c|c|c|}
\cline { 2 - 3 } \multicolumn{1}{c|}{} & Operar & Ordenar operar \\
\hline Prohibido & Operar (realizar operación) & Impartir y cancelar una orden \\
\hline Permitido (indiferente) & $\begin{array}{c}\text { Omitir operar } \\
\text { (abstenerse de realizar } \\
\text { operación) }\end{array}$ & $\begin{array}{c}\text { Mantener } \\
\text { una orden }\end{array}$ \\
\hline
\end{tabular}


BASCUÑÁN, Antonio. "Posesión, uso y explotación de la información privilegiada como elementos del insider trading en el derecho comparado del mercado de valores".

Estas conclusiones son enteramente compatibles con la vigencia de una prohibición de operar en posesión de información privilegiada, es decir, con el reconocimiento de un deber de abstención cuya infracción no requiere que se compruebe el uso de la información, tal como la SVS sostiene que existe en el derecho chileno ${ }^{8}$. El examen del derecho comparado demuestra que la cuestión fundamental en materia de responsabilidad del autor de la orden no radica en afirmar una prohibición de operación en explotación, uso o mera posesión de la información privilegiada -como la SVS obstinadamente pretende-, sino en asumir que la prohibición de operar en posesión de información privilegiada (el deber de abstención de la SVS) es sobreinclusiva y que por eso necesita reconocer excepciones, dentro de las cuales se encuentra la mantención inalterada de una orden impartida con anterioridad a la posesión de información privilegiada, esto es, la defensa de la orden previa.

La demostración de esta tesis es el objetivo de este artículo. Con ese propósito, en lo que sigue primero (2) expondré la distinción entre posesión, uso y explotación de la información privilegiada. Luego examinaré esa distinción y el estatus de la orden previa en (3) el derecho federal estadounidense, (4) el derecho europeo y (5) el derecho español. Finalmente (6) ofreceré algunas conclusiones derivadas de este análisis de derecho comparado.

Este artículo se refiere al derecho de los Estados parte de la Unión Europea que se encontraba vigente al 16 de abril de 2014, esto es, la fecha de aprobación del RAM. En el intertanto, esos Estados han debido recibir en su derecho interno las normas de comportamiento y de sanción impuestas por el RAM y la Directiva 2014/57/UE, del Parlamento Europeo y del Consejo, también de 16 de abril de 2014. Este artículo no examina ese proceso de recepción. En todo caso, la evolución de los derechos estatales europeos bajo el RAM y su Directiva no hace sino confirmar la corrección de la tesis que aquí se sostiene: los arts. 8 y 9 RAM, aplicables desde el 3 de julio de 2016, son las normas del derecho comparado del mercado de valores que afirman del modo más nítido y categórico la idea de que la prohibición del insider trading debe permitir la ejecución de órdenes previas y prohibir su cancelación. Es decir, exactamente lo opuesto a lo que la SVS sostiene que impone el derecho chileno del mercado de valores.

\section{La distinción entre la posesión, el uso y la explotación como presupuestos de la definición del insider trading.}

El insider trading presupone en su caso paradigmático la realización de una operación con valores cuyo precio podría verse afectado por la divulgación de información aún no divulgada. El fundamento de su prohibición se encuentra en algún tipo de relación entre esa operación y esa información, que se da en la persona que realiza la operación, ya sea que lo haga directamente o indirectamente mediante un intermediario. Esa relación entre la información y la operación puede darse en tres niveles, de menor a mayor intensidad, siendo siempre el de menor intensidad un presupuesto del nivel de mayor intensidad: (i) posesión de la información, (ii) uso de la información poseída, y (iii) explotación de la información poseída.

\footnotetext{
${ }^{8}$ El mismo Fried es partidario del estándar de posesión como criterio de interpretación de la Regla 10b5-1(b) SEC, porque considera que el estándar de uso es demasiado ambiguo.
} 
Polít. crim. Vol. 12, No 23 (Julio 2017), Art. 13, pp. 453-532.

[http://www.politicacriminal.cl/Vol_12/n_23/Vol12N23A13.pdf]

En tanto presupuesto del insider trading, la posesión de la información consiste en su conocimiento 9 . Los términos con que las distintas regulaciones del derecho comparado se refieren a ella son equivalentes: "estar en posesión de" (R 14e-3(a) SEC ${ }^{10}$, arts. 184 y 187bis TUF) ${ }^{11}$, “disponer de" (art. 8-1 RAM en sus versiones en español, francés, italiano y portugués $^{12}$, art. 81-2-a) LMV-E ${ }^{13}$, art. L 465-1 CMF) ${ }^{14}$, “tener" (\$ 52-(1) y -(3) CJA1993) ${ }^{15}$, "poseer" (art. 2-1 DAM ${ }^{16}$, art. 8-1 RAM ${ }^{17}$ en su versión en inglés), Sección 1.3.3. MAR $^{18}$, art. 2-1 de la Ley italiana $157 / 1991$, de 17 de mayo) ${ }^{19}$. La redacción de la prohibición originaria del insider trading en el derecho suizo ponía de manifiesto el carácter cognitivo de este presupuesto, en la medida que describía la acción como "aprovechar el conocimiento (die Kenntnis) de un hecho confidencial",20. Del mismo modo, la regla federal estadounidense de presunción del uso a partir de la posesión se refiere a ésta como "estar consciente de ([to be] aware of) la información""

El uso de la información confidencial poseída, como modo específico de operar, consiste en hacerla valer como una razón o un motivo de la decisión de realizar la operación. La regla federal estadounidense de presunción del uso a partir de la posesión explicita este sentido al referirse a este presupuesto como realizar la operación "sobre la base de" (on the basis of) la información privilegiada ${ }^{22}$. La prohibición administrativa inglesa, establecida en el art. 118 FSMA emplea una expresión similar, evidentemente adoptada de la formulación estadounidense: comportamiento que "está basado en" (is based on) información privilegiada $^{23}$. Desde 2003 el derecho común europeo emplea la expresión "utiliza" para describir el insider trading, dejando sin embargo en la ambigüedad en qué consiste esa utilización ${ }^{24}$. Fiel al derecho comunitario, la regulación administrativa francesa establece el deber de abstenerse de "utilizar" la información que se posee ${ }^{25}$. El CP-E emplea como única descripción objetiva de la acción la fórmula "usar de alguna información"26. Por último, el derecho alemán, esto es, la WpHG, emplea desde su modificación en 2004 una fórmula que es inequívocamente expresiva de que en la estructura de la infracción la

\footnotetext{
${ }^{9}$ En tanto presupuesto de la infracción consistente en la revelación de información privilegiada, la posesión podría consistir en la mera custodia de los soportes que contienen la información, si la omisión de evitación del acceso indebido por otro a esos soportes cuenta como revelación ilícita (en comisión por omisión). La cuestión no es relevante para este artículo.

${ }^{10}$ Infra, sección 2.2

${ }^{11}$ Infra, nota ${ }^{\circ} 130$.

${ }^{12}$ Infra, sección 3.4.

${ }^{13}$ Infra, sección 4.1.

${ }^{14}$ Infra, notas n ${ }^{\circ} 213$ y 214.

${ }^{15}$ Infra, nota $\mathrm{n}^{\circ} 131$.

${ }^{16}$ Infra, sección 3.2.

${ }^{17}$ Infra, sección 3.4.

${ }^{18}$ Infra, sección 3.5.2.

${ }^{19}$ Infra, nota ${ }^{\circ} 129$.

${ }^{20}$ Infra, nota 126.

${ }^{21}$ R 10b5-1(b) SEC: infra, sección 2.1.

${ }^{22} \mathrm{R}$ 10b5-1(a) y (b) SEC: infra, sección 2.4.

${ }^{23}$ Infra, nota $\mathrm{n}^{\circ} 144$.

${ }^{24}$ Infra, secciones 3.2, 3.4.

${ }^{25}$ Infra, nota ${ }^{\circ} 216$.

${ }^{26}$ Art. 285: infra, sección 4.2.
} 
BASCUÑÁN, Antonio. "Posesión, uso y explotación de la información privilegiada como elementos del insider trading en el derecho comparado del mercado de valores".

utilización de la información es un modo de realizar la operación: “adquirir o enajenar (...) valores utilizando información de insider",27.

La descripción del insider trading como "explotación" o "aprovechamiento" de la información privilegiada corresponde a la regulación originaria francesa del insider trading, contenida en el art. 10-1 de la Ordenanza $\mathrm{N}^{\circ}$ 67-833, de 28 de septiembre de 1967, introducido por la Ley $\mathrm{N}^{\circ} 70-128$, de 23 de diciembre de 1970, que exigía como elemento del delito el que se realizar la operación "explotando" la información ${ }^{28}$. En el nivel más general europeo está formulación se estableció con ocasión de la transposición del art. 2-1 de la DIT $^{29}$ al derecho suizo en $1988^{30}$ y al derecho alemán en $1994^{31}$. El derecho comunitario exigía que la operación con los valores a los cuales se refería la información de que se disponía/poseía tuviera lugar "explotándola con conocimiento de causa"32. El derecho suizo y el derecho alemán transpusieron esa prohibición describiendo la acción como "aprovechar" el conocimiento (Suiza), u operar "aprovechando" el conocimiento (Alemania). Como antes se dijo, el derecho alemán siguió al derecho común europeo en la sustitución de la mención a la explotación de la información por la mención a su utilización. El derecho suizo, en cambio, mantiene la descripción del insider trading como explotación de la información, a pesar de haber introducido considerables reformas en su regulación siguiendo la evolución del derecho común europeo ${ }^{33}$. Conforme al desarrollo por la doctrina alemana, la explotación de la información es una forma intensificada o cualificada de uso que se caracteriza por dos rasgos: (a) hace del conocimiento de la información la razón o motivo sine qua non de la operación, y (b) presupone el propósito de lograr una ventaja respecto de la contraparte en la operación, consistente en obtener un beneficio económico o evitar una pérdida ${ }^{34}$.

\footnotetext{
${ }^{27}$ Infra, nota $\mathrm{n}^{\circ} 145$.

${ }^{28}$ Infra, nota $\mathrm{n}^{\circ} 210$.

${ }^{29}$ Infra, sección 3.1 .

${ }^{30}$ Infra, nota $\mathrm{n}^{\circ} 126$.

${ }^{31}$ Infra, nota $\mathrm{n}^{\circ} 127$.

${ }^{32}$ Las versiones en alemán, francés, italiano y portugués coinciden con la sintaxis de la versión en español. Tratándose de la versión en inglés, si bien ella emplea la expresión equivalente "aprovechándola" (taking advantage of), su sintaxis admite una interpretación distinta del aprovechamiento, no ya como modo de comisión sino como denominación de la operación en posesión de información. Al respecto, infra, sección 3.1 .

${ }^{33}$ Infra, nota ${ }^{\circ} 146$.

34 SETHE, Roth, "Insiderrecht", en: ASSMANN, Hans-Dieter, SCHÜTZE, Rolf A., Handbuch des Kapitalanlagerrechts. München: C.H. Beck, (2015), § 8 número marginal ("nm.") 94; KÖHLER, Diana (2013), § 8 - "Wertpapierhandelsgesetz", en: PARK, Tido, (ed.), Nomos Kommentar, Kapitalmarktstrafrecht. Baden-Baden: Nomos ( $3^{\mathrm{a}}$ ed.), $\S 8$ nm. 139; PANANIS, Panos, § 38 - "Wertpapierhandelsgesetz", en: Münchener Kommentar zum Starfgesetzbuch, Tomo 6/1, Nebenstrafrecht II. München: C.H. Beck, $2010, \S 8$ nm. 64; ROLSHOVEN, Max Philipp (2010), “Anmerkung zum EUGH: Nutzung von Insiderinformationen nach der Marktmissbrauchtsrichtlinie - Spector Photo Group NV", BKR - Zeitschrift für Bank- und Kapitalmarktrecht 2010 pp. 74-77; HOPT, Klaus J., "Problemática de la publicidad de la información privilegiada y ad hoc", en: del mismo, Estudios de derecho de sociedades y de mercado de valores. Madrid: Marcial Pons, 2010 (publicación original en alemán en 2007), pp. 459-522, pp. 476-477; WEHOWSKY, Ralf (2010), "Kommentar-WpHG", en: ERBS, Georg, KOHLHAAS, Max, AMBS, Friedrich et al, Strafrechtliche Nebengesetze. Tomo IV. München: C.H. Beck (178a entrega), 2010, § 14 nm. 4-5.
} 
Polít. crim. Vol. 12, No 23 (Julio 2017), Art. 13, pp. 453-532.

[http://www.politicacriminal.cl/Vol_12/n_23/Vol12N23A13.pdf]

Siguiendo un uso adoptado por el Tribunal Europeo en el caso Spector (2006) ${ }^{35}$ y recogido por el art. $8^{\circ} \mathrm{RAM}^{36}$, para referirse a la prohibición del insider trading de modo neutral a la cuestión de si se presupone explotación, simple uso o mera posesión, en adelante se hablará de la "prohibición de operación con información privilegiada" ("PO"). Cuando la formulación de esa prohibición no suponga otro requisito que la posesión de la información privilegiada así se lo explicitará, denominándosela "prohibición de operación en posesión de información privilegiada" ("POP”). Cuando además de la posesión la formulación de la prohibición suponga como requisito el uso de la información privilegiada también se lo explicitará, denominándosela "prohibición de operación en uso de información privilegiada" ("POU") 37 . En cuanto a la explotación, su previsión por la prohibición como elemento de la infracción o delito se entenderá en lo sucesivo como un estándar intensificado de POU.

\subsection{La explicación de la distinción entre posesión y uso.}

La distinción entre posesión y uso es explicada en la doctrina y jurisprudencia comparadas recurriendo a dos criterios: (i) la causalidad, y (ii) la intencionalidad.

Es usual entender que mientras que la operación en posesión de la información supone un nexo puramente cronológico entre las operaciones que constituyen la operación y el conocimiento que constituye la posesión de información, la operación en uso y la operación en explotación de la información suponen además un nexo de causalidad psíquica entre la información poseída y la operación realizada. Aunque la idea de una causalidad psíquica pueda resultar problemática, lo que se quiere decir con ello es bastante claro. La operación en uso o explotación de la información supone que el conocimiento de ésta contribuye como razón o como motivo en la deliberación del agente que precede y justifica o explica su decisión de realizar la operación. A su vez, la distinción entre uso y explotación se basa en el grado de intensidad de esa conexión causal: la explotación supone que el conocimiento de la información es la causa necesaria de la operación, de modo que si no la hubiera poseído ella no se habría realizado. El uso sólo supone que el conocimiento de la información haya influido en la causación de la operación. En la expresiva formulación de la agencia administrativa alemana, la Bundesanstalt für Finanzdienstleistungsaufsicht: "El insider utiliza información privilegiada cuando actúa en conocimiento de la información y al hacerlo deja que la información tenga influencia en su actuar"38.

\footnotetext{
${ }^{35}$ Infra, sección 3.3 .

${ }^{36}$ Infra, sección 3.4.

${ }^{37}$ La POU siempre es una "PUO", es decir, una prohibición de uso operativo de la información privilegiada; en otras palabras, siempre se refiere a un uso respecto de una acción específica: la utilización como razón o motivo para realizar una operación en el mercado de valores. En el derecho comparado del mercado de valores no existe una prohibición genérica de uso de la información privilegiada como la que es característica de los deberes fiduciarios, por ejemplo, los que recaen sobre los agentes del gobierno corporativo. El hecho de que la Ley 18045 contemple esa prohibición, junto a un deber genérico de guardar reserva, como las primeras normas dirigidas a los poseedores de información privilegiada (art. 165 inciso primero) se explica como una transposición irreflexiva de la regulación de las sociedades anónimas (arts. $42 \mathrm{~N}^{\circ}$ 6, 43 y 50 de la Ley 18046).

${ }^{38}$ Emittentenleitfaden III.2.2.2.1: "Der Insider verwendet Insiderinformationen, wenn er in Kenntnis der Information handelt und dabei die Information in sein Handeln mit einfließen last". Conformes: SETHE, "Insiderrecht", cit. nota $n^{\circ} 34, \S 8$ nm. 95; KÖHLER, "Wertpapierhandelsgesetz", cit. nota n $34 \S 8$ n. 140;
} 
BASCUÑÁN, Antonio. "Posesión, uso y explotación de la información privilegiada como elementos del insider trading en el derecho comparado del mercado de valores".

Igualmente extendida se encuentra la explicación de la distinción entre operación en posesión de información privilegiada y operación en uso o explotación de información privilegiada como si ésta última requiriera un elemento intencional y no así aquélla. Conforme a esta explicación la POP establecería una responsabilidad objetiva o estricta, mientras que la POU establecería una responsabilidad basada en una culpabilidad subjetiva. Esta manera de explicar la diferencia se basa en una premisa correcta y fácil de entender. La causalidad psíquica requerida conforme a la explicación objetiva supone la concurrencia de una deliberación que toma en consideración la información como razón o motivo. La atribución de una mínima racionalidad económica al autor de la operación exige atribuirle conciencia de esa deliberación. Allí hay un elemento subjetivo. Por eso tiene sentido sostener que la POU supone como elemento de la infracción una intencionalidad específica que no supone la POP. Pero de eso no se sigue que la POP no presuponga intencionalidad alguna. Si la posesión de información consiste en su conocimiento, allí hay también un elemento subjetivo presupuesto por la descripción de la infracción. Y desde luego la atribución de responsabilidad por la infracción de la prohibición supone la satisfacción de las reglas generales de imputación subjetiva que el sistema suponga para la justificación de la sanción en cuestión ${ }^{39}$.

Esclarecido el sentido de una y otra explicación, se tiene que en rigor ambas describen un mismo rasgo o aspecto de la estructura de la infracción, explicitado por la POU. Ella supone una conexión de sentido ente el conocimiento de la información y la realización de la operación que corresponde a la relación de implicación del silogismo práctico: ceteris paribus la realización de la operación es la acción racional dada la información que se posee. Se trata por lo tanto de una relación que es intersubjetivamente constatable. La asociación de esa conexión racional de sentido con una tendencia interna trascendente es natural y obvia, pues la acción es racional desde el punto de vista de la racionalidad económica: es apta para producir una buena inversión (propósito de obtener un beneficio económico) o para evitar una mala inversión (propósito de evitar una pérdida económica). Por esta razón, el elemento subjetivo adicional atribuido a la exigencia de explotación o aprovechamiento de la información no es más que una explicitación de la conexión racional de sentido. La doctrina de modo unánime entiende que la exigencia de elementos subjetivos específicos -esto es, la exigencia de explotación en su comprensión como intencionalidadrestringe el alcance del supuesto de la prohibición o como mínimo hace más difícil la prueba de su realización. Pero eso sólo ese efectivo si esos elementos subjetivos se entienden como correlato de elementos objetivos de la infracción ${ }^{40}$. De lo contrario, la

PANANIS “Wertpapierhandelsgesetz", cit. nota n 34, § 8 nm. 66; HOPT, "Problemática”, cit. nota n 34, pp. 476-477; WEHOWSKY, "Kommentar-WpHG, cit. nota ${ }^{\circ} 34 \S 14 \mathrm{~nm} .5$.

${ }^{39} \mathrm{Se}$ incurre en un error semejante cuando se compara, en las regulaciones que hacen la diferencia entre la prohibición dirigida a cualquier poseedor, que presupone conocimiento del origen de la información, y la prohibición dirigida al círculo de insiders que ostentan ciertas calidades personales, que no la presupone (por ejemplo, R 14e-3(a) SEC, arts. 2.1 y 4 DIT, art. 2-1 DAM), y se deduce que ésta última establece una responsabilidad objetiva o estricta. Esto es un error: del hecho que una prohibición no exija un elemento subjetivo específico no se deduce que la atribución de responsabilidad por su infracción no haya de satisfacer estándar alguno de imputación subjetiva.

${ }^{40}$ Las exigencias objetivas pueden ser de producción de un resultado (como en el caso del CP-E) o de idoneidad para producir un resultado (como en el caso de la WpHG entre 1994 y 2004). Esta segunda 
Polít. crim. Vol. 12, № 23 (Julio 2017), Art. 13, pp. 453-532.

[http://www.politicacriminal.cl/Vol_12/n_23/Vol12N23A13.pdf]

comprensión de la conexión racional de sentido como mero elemento subjetivo puede eventualmente facilitar la prueba -por ejemplo, si hay antecedentes de que no obstante ser discutible la probable incidencia de la información sobre el precio el agente así lo estimó- e incluso extender el alcance del supuesto de hecho, abarcando lo que de otro modo sería una tentativa inidónea de cometer la infracción. Lo que sí marca una diferencia importante en el alcance del supuesto de hecho y la prueba de su realización es la distinción entre operación en posesión y operación en uso de la información privilegiada.

\subsection{El estándar estricto de posesión.}

La POP configura un supuesto de hecho que conforme a su tenor literal se realiza con tal que exista simultaneidad entre el conocimiento de información privilegiada y la ejecución de una operación con instrumentos a los que esa información se refiere ${ }^{41}$. Así definida, la POP es manifiestamente sobreinclusiva, es decir, abarca casos que manifiestamente no merecen ni necesitan ser calificados como ilícitos ni ser sancionados, y su sobreinclusividad es manifiestamente disfuncional para el mercado de valores. A lo largo de este artículo serán examinados los principales casos de operaciones con información privilegiada que el derecho comparado reconoce como correctos y funcionales al orden del mercado de valores. En este lugar basta mencionar tres:

(i) las operaciones rutinariamente realizadas por intermediarios en ejecución de las órdenes de sus clientes;

(ii) la prestación de servicios múltiples de asesoría financiera por personas jurídicas;

(iii) los planes de inversión definidos por insiders de emisores sin posesión de información privilegiada y comunicados a un mandatario para su ejecución posterior.

Como es evidente, un intermediario puede encontrarse en la situación de poseer información privilegiada relativa a valores sobre los cuales recibe órdenes de efectuar operaciones de parte de otros clientes. Como también es evidente, las personas jurídicas que prestan servicios múltiples de asesoría financiera poseen información privilegiada relativa a algunos de sus clientes. Si esa posesión generara el intermediario o para los agentes de la persona jurídica una prohibición de realizar operaciones, éstos no podrían ejecutar órdenes relativas a esos valores. El derecho comparado reconoce al intermediario la legitimidad del cumplimiento de órdenes sobre valores respecto de los cuales él posee información privilegiada; también reconoce a las personas jurídicas la legitimidad de la prestación de servicios múltiples de asesoría financiera, bajo la condición de que adopte medidas y procedimientos para evitar el flujo de información desde la asesoría a la operación en el mercado de valores.

Como también es evidente, los insiders de emisores tienen un interés legítimo en invertir en valores del emisor. Pero los insiders se encuentran continuamente expuestos a poseer

alternativa da a la prohibición de operación con explotación o aprovechamiento de la información la estructura de una "infracción de resultado cortado" (si es punible, "delito de resultado cortado").

${ }^{41}$ Como es bien sabido, las propiedades que debe reunir la información para constituir información privilegiada y la relación que debe existir entre esa información y los instrumentos sobre los cuales versa la operación generan un buen número de cuestiones controvertidas. Ninguna de ellas es relevante sin embargo para este artículo: como hipótesis de trabajo se asume que el análisis siempre se refiere a la posesión de información que constituye información privilegiada según la regulación. 
BASCUÑÁN, Antonio. "Posesión, uso y explotación de la información privilegiada como elementos del insider trading en el derecho comparado del mercado de valores".

información privilegiada relativa a los valores del emisor por lapsos sucesivos. De aplicárseles la POP deberían interrumpir sus operaciones cada vez que conocieran información privilegiada. Eso hace impracticable una inversión planificada. La única manera de hacer posible la inversión de los insiders de un emisor en los valores del emisor bajo una POP es admitiendo como excepción a la prohibición la operación en ejecución de una orden impartida con anterioridad a la posesión de información privilegiada. Como se verá en este artículo, esta es una regla extendida en el derecho comparado.

\subsection{Los estándares estricto y moderado de uso.}

La POU configura un supuesto de hecho que conforme a su tenor literal exige para su realización la concurrencia de los mismos requisitos que la $\mathrm{POP}$, y además, que el conocimiento de la información influya en la decisión de realizar la operación. Así definida, la POU es prima facie ortoinclusiva ${ }^{42}$, es decir, sólo abarca en principio casos que manifiestamente merecen y necesitan ser calificados como ilícitos y ser sancionados. Ello se debe a que la POU no padece los tres problemas de sobreinclusividad recién señalados: el intermediario no usa la información privilegiada que posee cuando se limita a ejecutar la orden de un tercero, la persona jurídica no usa la información privilegiada que posee cuando sus agentes proceden incomunicadamente unos de otros, y el insider del emisor tampoco usa la información privilegiada que posee cuando su mandatario de limita a ejecutar la orden que el insider impartió antes de poseer esa información.

La aplicación de la POU puede sin embargo imponer una carga probatoria difícil de satisfacer por el acusador, dependiendo de la intensidad de la conexión racional de sentido que se atribuya al uso como elemento de la infracción. Mientras más intensa se estime que ha de ser esa conexión, o sea, mientras más peso se exija atribuir a la información como razón o motivo de la decisión, mayor es la facilidad que tiene el acusado de producir evidencia contraria a la acusación, mostrando la diversidad de razones o motivos distintos del conocimiento de esa información que influyeron en la adopción de la decisión de realizar la operación. Es importante observar que esta dificultad de prueba, extendidamente atribuida en el derecho comparado a la POU, no se debe a las características fácticas inherentes al insider trading así definido que lo hagan difícil de constatar, sino que es consecuencia de la interpretación que se haga de la ley.

Existen dos maneras de enfrentar la dificultad anterior. La primera es interpretar el uso como elemento de la infracción en un sentido menos exigente como causalidad psíquica, como un "conocer la información y dejarla que influya en la decisión" en la expresión de la autoridad administrativa alemana ${ }^{43}$. El hecho de que esta sea la concepción dominante en la

\footnotetext{
${ }^{42}$ La expresión “ortoinclusivo(a)" (“ortoinclusividad”) es estipulativa. El prefijo "orto" derivado del griego orthos -no la palabra, que viene del latín ortus-, significa "recto" o "correcto". Relacionado con la inclusividad de la norma significa que el sentido literal de la regla cubre todos los casos que corresponden a su sentido pragmático. Una regla ortoinclusiva es una regla respecto de la cual se puede predicar una situación de isomorfia en el sentido de la terminología acuñada por Wróblewski: a su respecto no hay controversia interpretativa originada por una disparidad de alcances entre algunos de sus posibles sentidos (WRÓBLEWSKI, Jerzy, The Judicial Application of Law, editado por Zenon Bankowski, Dordrecht/Boston: Kluwer, 1992, pp. 96 y ss.). Luego, a su respecto no se genera la necesidad de una interpretación correctiva.

${ }^{43}$ Supra, nota ${ }^{\circ} 38$.
} 
Polít. crim. Vol. 12, № 23 (Julio 2017), Art. 13, pp. 453-532.

[http://www.politicacriminal.cl/Vol_12/n_23/Vol12N23A13.pdf]

cultura jurídica alemana explica que esa doctrina sea escéptica respecto de la pretendida dificultad de prueba del hecho del uso de la información ${ }^{44}$. La segunda es reconocer una regla de inferencia, esto es, una presunción, basada en las máximas de la experiencia: respecto de todo agente dotado de racionalidad económica que posee información y actúa en un sentido racionalmente consistente con esa información se puede presumir que usó la información al adoptar su decisión. La aplicación de la POU junto con la adopción de esta presunción configura un estándar moderado de uso, por contraste con el estándar estricto de uso $^{45}$.

\subsection{El estándar moderado de posesión.}

También la adopción de la POP tiene una vía para evitar el problema de sobreinclusividad que afecta esa formulación de la norma. Esa solución consiste en explicitar un criterio general o un catálogo suficiente de criterios especiales que fundamente el reconocimiento de excepciones ("puertos seguros" o "defensas afirmativas") ${ }^{46}$ a la prohibición. Este modelo regulativo configura un estándar moderado de posesión, por contraste con el estándar estricto de posesión ${ }^{47}$.

En sus resultados, el estándar moderado de uso y el estándar moderado de posesión son semejantes: los casos en que manifiestamente la operación no se realiza en uso de la información poseída no generan responsabilidad por infracción de la $\mathrm{POP}^{48}$. En sus fundamentos hay sin embargo una diferencia. Bajo el estándar moderado de uso ese resultado procede de la refutación de una presunción adversa. Bajo el estándar moderado de posesión ese resultado procede de la invocación de una excepción reconocida por la regulación, ya sea en términos explícitos o implícitamente. La semejanza en los resultados

\footnotetext{
${ }^{44}$ Esto se ve confirmado cuando se revisa las críticas a la POU. Por lo general esas críticas suponen que la POU requiere probar que el conocimiento de la información fue la razón o motivo determinante de la decisión de realizar la operación; esto implica considerarla como causa necesaria o sine qua non (but-for cause) de la operación. Al respecto, en un estudio comparativo del derecho anglonorteamericano (Canadá, Estados Unidos, Reino Unido, Australia) previo al caso Spector, HUANG, Hui, "The Insider Trading 'Possession Versus Use' Debate: An International Analysis”, Securities Regulation Law Journal n 33 (2005), pp. 130155. En los términos del derecho alemán, eso equivale a entender la POU como prohibición de operación en explotación de la información.

${ }^{45}$ La terminología procede de HUANG “The Insider Trading”, cit. nota $n^{\circ} 44$.

${ }^{46}$ Una "defensa afirmativa" tiene la estructura y sentido de una causa de justificación según la teoría de la diferenciación entre la tipicidad y la antijuridicidad: admite la realización del tipo y con ello la infracción prima facie de una norma de comportamiento, pero sostiene que la concurrencia de razones adicionales fundamentan en definitiva la autorización del comportamiento. Es decir, para el caso excepcional la defensa afirmativa derrota la prohibición general. Un "puerto seguro" es una excepción que se entiende como afirmación de que el comportamiento por ella abarcado no infringe la norma respectiva. La técnica legislativa extendida consiste en establecer puertos seguros respecto de prohibiciones o reglas de imputación formuladas mediante estándares elásticos, para reducir la inseguridad que genera esa elasticidad.

${ }^{47}$ También según HUANG "The Insider Trading", cit. nota ${ }^{\circ} 44$.

${ }^{48}$ En SEC v. Lipson, 278 F.3d 656, § 9 (2003) el Juez Posner sostuvo que una instrucción al jurado que concedía al acusado la posibilidad de refutar una presunción de uso era "similar" a una excepción legal establecida a la prohibición de posesión consciente. Para un análisis de esta sentencia y las posibilidades de interpretar la R 10b5-1 SEC como estándar de uso, WARNER, Kevin E., "Rethinking Trades 'On the Basis Of' Inside Information; Some Interpretations of SEC Rule 10b5-1”, Boston University Law Review $\mathrm{n}^{\circ} 83$ (2003), 281-314.
} 
BASCUÑÁN, Antonio. "Posesión, uso y explotación de la información privilegiada como elementos del insider trading en el derecho comparado del mercado de valores".

se debe, por supuesto, a que estas excepciones corresponden a casos en que habiendo inequívocamente posesión de información -es decir, realizándose el supuesto de hecho de la POP - es sin embargo manifiesto que esa información no constituyó una razón o motivo de la decisión de realizar la operación - es decir, no se satisfizo el estándar de uso-. Eso da pie para sostener que el estándar moderado de posesión en rigor reconoce que el fundamento de la ilicitud del insider trading es el uso de la información privilegiada y que la aplicación de un estándar estricto de posesión constituiría una restricción desproporcionada del derecho de propiedad o de la libertad económica por resultar excesiva (sobreinclusiva) en relación al logro de la finalidad que persigue.

Como se verá, la regulación federal estadounidense, el derecho común europeo y la regulación española configuran estándares modificados, incluyendo dentro de los casos que refutan la presunción o se exceptúan de la prohibición, ya sea de operación en uso o en posesión de la información privilegiada, a la orden o plan previo del insider del emisor.

\section{La distinción entre uso y posesión en la regulación federal estadounidense.}

Como es bien sabido el derecho federal estadounidense no tiene una única regulación prohibitiva del insider trading, sino dos: una prohibición de carácter general y otra prohibición específica para contextos de tender offers ${ }^{49}$. La prohibición específica es directa y explícita: la SEC la estableció el año 1980 describiendo expresamente el comportamiento que constitutivo de insider trading prohibido. La prohibición genérica es indirecta e implícita: la SEC la estableció el año 1948 prohibiendo el fraude en conexión con operaciones, sin describir expresamente el insider trading como modalidad de fraude. La calificación del insider trading como fraude es el resultado de la aceptación parcial y fragmentaria por la jurisprudencia estadounidense de una interpretación de la prohibición del fraude sostenida por la SEC desde 1961.

\subsection{La prohibición general indirecta de insider trading (R 10b-5 SEC) ${ }^{50}$.}

La R 10b-5 SEC en su redacción actual dispone:

"Employment of manipulative and deceptive devices.

It shall be unlawful for any person, directly or indirectly, by the use of any means or instrumentality of interstate commerce, or of the mails or of any facility of any national securities exchange,

(a) To employ any device, scheme, or artifice to defraud,

\footnotetext{
${ }^{49} \mathrm{O}$ tres, si se cuenta la prohibición del short-swing profit (§ 16b SEA) dentro de ellas: infra, sección 2.6.

50 STEINBERG, Marc I., Securities Regulation. New York, Law Journal Pres (54 a entrega), 2012, §§ 3.043.06; LOSS, Louis, SELIGMAN, Joel, PAREDES, Troy, Fundamentals of Securities Regulation. New York: Wolters Kluwer (6a ed.), 2011, pp. 1287-1407; LANGEVOORT, Donald D., Insider Trading Regulation, Enforcement \& Prevention. Securities Law Series, Volume 18. Danvers MA: Thompson Reuters/West, 2010, $\S \S$ 2:1-4:13, 6:1-6:14; WANG, William K.S., STEINBERG, Marc I., Insider Trading. Oxford: Oxford University Press (3a ed.), 2010, $\S 5.1-5.4,6$; HAZEN, Thomas Lee, Treatise on the Law of Securities Regulation. St. Paul MN: Thompson/Reuters/West (6a ed.), 2009, § 12.17.
} 
Polít. crim. Vol. 12, № 23 (Julio 2017), Art. 13, pp. 453-532.

[http://www.politicacriminal.cl/Vol_12/n_23/Vol12N23A13.pdf]

(b) To make any untrue statement of a material fact or to omit to state a material fact necessary in order to make the statements made, in the light of the circumstances under which they were made, not misleading, or

(c) To engage in any act, practice, or course of business which operates or would operate as a fraud or deceit upon any person, in connection with the purchase or sale of any security." 51

En 1961 la SEC sostuvo que toda persona que conoce información privilegiada tiene respecto de sus contrapartes en las operaciones en el mercado de valores un deber fiduciario que la obliga a revelar la información o a abstenerse de la operación, de modo tal que quien realiza la operación en posesión de la información incurre en fraude de la contraparte (letra c) de la R 10b-5 SEC) ${ }^{52}$. Aunque esa tesis tuvo inicialmente éxito en la Corte de Apelaciones del Segundo Circuito $^{53}$, ella nunca ha sido aceptada por la USSC. La jurisprudencia de este tribunal sostiene en cambio que una operación en uso o posesión de información privilegiada constituye fraude si y solo si concurren elementos que justifiquen excepcionalmente un deber fiduciario respecto de la contraparte (teoría clásica) o respecto de la fuente de la información (teoría de la misappropriation).

Conforme al cuerpo de jurisprudencia de la USSC puede afirmarse que cometen fraude por infracción de un deber fiduciario:

(a) los insiders primarios del emisor (holding de Chiarella v. Unites States ${ }^{54}$ y Dirks v. United States) ${ }^{55}$;

(b) los insiders temporales o constructivos del emisor (nota 14 de Dirks v. Unites States $)^{56}$

(c) los tippees de insiders primarios o constructivos del emisor (nota 12 de Chiarella $v$. United States $^{57}$ y holding de Dirks $v$. United States $)^{58}$;

(d) los outsiders del emisor que tienen un deber fiduciario para con la fuente propietaria de la información (United States v. O’Hagan) ${ }^{59}$; en relación con esta categoría, la Regla

\footnotetext{
${ }^{51}$ Disponible en:

http://www.ecfr.gov/cgi-bin/text-

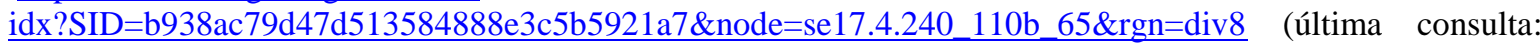
25.11.2016).

${ }^{52}$ In Re Cady \& Roberts Co. 40 SEC 907 (1961).

${ }^{53}$ SEC v. Texas Gulf Sulphur Co., 401 D.2d 833, 851-52 (1968); certioriari denegado bajo Kline v. SEC 394 U.S. 976 (1969); Crane v. Westinghouse Air Brale Co., 419 F.2d 787 (2 Cir. 1969), certiorari denegado 400 U.S. 822 (1970), Radiation Dynamics, Inc. v. Goldmuntz, 464 F.2d 876 (2 Cir. 1972), United States v. Brown, 555 F.2d 336 (2d Cir. 1977); Shapiro v. Merril Lynch, Pierce, Fenner \& Smith, Inc. 495 F.2d 228 (2d Cir 1978); United States v. Chiarella 588 F. 2d 1358 (2 Cir. 1978).

${ }^{54} 445$ U.S. 222 (1980), 227-230.

${ }^{55} 463$ U.S. 646 (1983), 657-658, citando 445 U.S. 231-232.

56463 U.S. 646 (1983), 655.

57445 U.S. 222 (1980), 231, citando entre otras decisiones a Shapiro v. Merrill Lynch, Pierce, Fenner \& Smith, Inc., 495 F.2d 228, 237-238 (2 Cir. 1974), y considerando que ese deber surge del rol del tippee como participant after the fact (encubridor) en la infracción al deber fiduciario cometida por el insider.

${ }^{58} 463$ U.S. 646 (1983), 660-661.

${ }^{59} 521$ U.S. 642 (1997), 652-656.
} 
BASCUÑÁN, Antonio. "Posesión, uso y explotación de la información privilegiada como elementos del insider trading en el derecho comparado del mercado de valores".

10b5-2 SEC definió en 2001 las condiciones bajo las cuales un outsider mantiene una relación fiduciaria con la fuente de la información ${ }^{60}$.

Esta jurisprudencia no resuelve claramente si el comportamiento constitutivo de fraude bajo la R 10b5-1 SEC requiere uso de la información privilegiada o si por el contrario basta con operar en posesión de ella para cometerlo. La controversia judicial respecto de este punto es lo que originó la R 10b5-1 SEC, establecida en 2001, como más adelante se examina (infra, sección 2.3).

\subsection{La prohibición especial directa de insider trading (R 14e-3(a) SEC) ${ }^{61}$.}

La R 14e-3(a) SEC en su redacción actual dispone en su parte pertinente:

"Transactions in securities on the basis of material, nonpublic information in the context of tender offers.

(a) If any person has taken a substantial step or steps to commence, or has commenced, a tender offer (the "offering person"), it shall constitute a fraudulent, deceptive or manipulative act or practice within the meaning of section 14(e) of the Act for any other person who is in possession of material information relating to such tender offer which information he knows or has reason to know is nonpublic and which he knows or has reason to know has been acquired directly or indirectly from:

(1) The offering person,

(2) The issuer of the securities sought or to be sought by such tender offer, or

(3) Any officer, director, partner or employee or any other person acting on behalf of the offering person or such issuer, to purchase or sell or cause to be purchased or sold any of such securities or any securities convertible into or exchangeable for any such

${ }^{60} \$ 240.10 b 5-2$ Duties of trust or confidence in misappropriation insider trading cases. / Preliminary note to $\S 240.10 b 5-2$ : This section provides a non-exclusive definition of circumstances in which a person has a duty of trust or confidence for purposes of the "misappropriation" theory of insider trading under Section 10(b) of the Act and Rule 10b-5. The law of insider trading is otherwise defined by judicial opinions construing Rule 10b-5, and Rule 10b5-2 does not modify the scope of insider trading law in any other respect. / (a) Scope of Rule. This section shall apply to any violation of Section 10(b) of the Act (15 U.S.C. 78j(b)) and $§ 240.10 b-5$ thereunder that is based on the purchase or sale of securities on the basis of, or the communication of, material nonpublic information misappropriated in breach of a duty of trust or confidence. / (b) Enumerated "duties of trust or confidence." For purposes of this section, a "duty of trust or confidence" exists in the following circumstances, among others: / (1) Whenever a person agrees to maintain information in confidence; / (2) Whenever the person communicating the material nonpublic information and the person to whom it is communicated have a history, pattern, or practice of sharing confidences, such that the recipient of the information knows or reasonably should know that the person communicating the material nonpublic information expects that the recipient will maintain its confidentiality; or / (3) Whenever a person receives or obtains material nonpublic information from his or her spouse, parent, child, or sibling; provided, however, that the person receiving or obtaining the information may demonstrate that no duty of trust or confidence existed with respect to the information, by establishing that he or she neither knew nor reasonably should have known that the person who was the source of the information expected that the person would keep the information confidential, because of the parties' history, pattern, or practice of sharing and maintaining confidences, and because there was no agreement or understanding to maintain the confidentiality of the information.

61 STEINBERG, Securities Regulation, cit. nota $\mathrm{n}^{\circ} 50, \S 3.08 ;$ LOSS/SELIGMAN/PAREDES, Fundamentals, cit. nota $\mathrm{n}^{\circ} 50, \S(2011)$, p. 1408-1412; LANGEVOORT, Insider Trading, cit. nota $\mathrm{n}^{\circ} 50, \S \S$ 7:1-7.10; WANG/STEINBERG, Insider Trading, cit. nota $\mathrm{n}^{\circ} 50, \S \S \S 9.1-9.2 ;$ HAZEN, Treatise, cit. nota $\mathrm{n}^{\circ}$ $50, \S \S 11.6[2][\mathrm{C}]$. 
Polít. crim. Vol. 12, No 23 (Julio 2017), Art. 13, pp. 453-532.

[http://www.politicacriminal.cl/Vol_12/n_23/Vol12N23A13.pdf]

securities or any option or right to obtain or to dispose of any of the foregoing securities, unless within a reasonable time prior to any purchase or sale such information and its source are publicly disclosed by press release or otherwise." 62

Esta regla fue establecida por la SEC en septiembre de 1980, como reacción anticipada a la decisión de la USSC en Chiarella $v$. United States ${ }^{63}$. La regla asegura la aplicación de la prohibición a cualquier poseedor de la información relativa a una inminente tender offer ${ }^{64}$, con tal que sepa o tenga razón para saber el origen de esa información y su condición de información no divulgada, ya sea en el oferente o en el emisor. Esto libera a la prohibición de insider trading de los estrechos límites a los que la confinó la teoría clásica sostenida por la USSC en Chiarella.

Como se puede apreciar, la R 14e-3(a) no sólo declara que el insider trading es constitutivo de fraude bajo la $\S 14$ e SEA ${ }^{65}$ sino que además describe el comportamiento constitutivo de insider trading ${ }^{66}$. Al describirlo la regla configura la infracción como operación en

${ }^{62}$ Disponible en:

http://www.ecfr.gov/cgi-

bin/retrieveECFR? $g p=\& S I D=b 938 a c 79 d 47 d 513584888 \mathrm{e} 3 \mathrm{c} 5 \mathrm{~b} 5921 \mathrm{a} 7 \& \mathrm{n}=\mathrm{pt} 17.4 .240 \& \mathrm{r}=$ PART\&ty=HTML\#s e17.4.240_114e 63 (última consulta: 25.11.2016).

${ }^{63} 445$ U.S. 222 (1980).

${ }^{64}$ La legislación estadounidense sobre valores no define el concepto de tender offer. En términos muy generales una tender offer es un modo de obtener el control de una sociedad en el cual un oferente ofrece comprar acciones de una sociedad que es su objetivo en un precio premium siempre que los accionistas vendan un cierto número de acciones (ALLEN, Samuel N., "The Scope of the Disclosure Duty under SEC Rule 14e-3”, Washington \& Lee Law Review n 38 (1981), pp. 1054-1073, p 1053). El criterio más generalizado de identificación de una tender offer es el test de Wellman v. Dikinson, 475 F. Supp. 783, 823824 (S.D.N.Y. 1979), 682 F. 2d 355 (2d Cir. 1982), certiorari denegado Dickinson v. SEC 460 U.S. 1069 (1983). El test se basa en ocho criterios propuestos por la SEC: (1) solicitación activa y extendida de valores de oferta pública, (2) solicitación hecha por un porcentaje sustancial de acciones del emisor; (3) oferta de compra hecha por sobre el precio de mercado, (4) los términos de la oferta son más bien firmes que flexibles, (5) la oferta se encuentra limitada a un número fijo de acciones, usualmente a un número fijo máximo, (6) la oferta se encuentra vigente sólo por un período limitado de tiempo, (7) el destinatario de la oferta se encuentra sujeto a una presión de vender sus acciones, (8) el anuncio público del programa de compra precede o acompaña una rápida acumulación de los valores del emisor que constituye el objetivo. Acerca de tender offers: Loss/Seligman/Paredes (2011), p. 834 y s.; Hazen (2009), 11.4, v. 3 p. 340-348.

65 " 15 USC 78n: Proxies. (....) (e) Untrue statement of material fact or omission of fact with respect to tender offer. It shall be unlawful for any person to make any untrue statement of a material fact or omit to state any material fact necessary in order to make the statements made, in the light of the circumstances under which they are made, not misleading, or to engage in any fraudulent, deceptive, or manipulative acts or practices, in connection with any tender offer or request or invitation for tenders, or any solicitation of security holders in opposition to or in favor of any such offer, request, or invitation. The Commission shall, for the purposes of this subsection, by rules and regulations define, and prescribe means reasonably designed to prevent, such acts and practices as are fraudulent, deceptive, or manipulative." Disponible en:

http://uscode.house.gov/view.xhtml?req=granuleid:USC-prelim-title15-section78n\&num=0\&edition=prelim (última consulta: 25.11.2016).

${ }^{66}$ La cuestión de si esta descripción explícita del insider trading como fraude bajo la $§ 14 \mathrm{e}$ SEA, lo mismo que la descripción explícita del tipping (revelación: R 14e3-(d) SEC) de información privilegiada como fraude bajo la misma norma, excede o no la competencia de la SEC conforme a los §§ 14e y 23(a) SEA fue objeto de controversia judicial hasta ser zanjada a favor de la competencia de la SEC por la USSC en United States v. O'Hagan, 521 U.S. 642 (1997), 673-673. Al respecto: RAYMOND, Michael T., "Validity Challenges to SEC Rile 14e-3", The John Marshall Law Review n 23 (1990), pp. 305-332; LIVINGSTON, B., HASKELL, E., “'Disclose-or-Abstain' Without Restraint: The Supreme Court Misses the Mark on Rule 
BASCUÑÁN, Antonio. "Posesión, uso y explotación de la información privilegiada como elementos del insider trading en el derecho comparado del mercado de valores".

posesión de información privilegiada, es decir, establece una POP: "constituirá [fraude] para cualquier otra persona que está en posesión de información relevante relativa a esa oferta (...) comprar o vender o causar que sea comprado o vendido cualquiera de esos valores (...)". Esta formulación de la regla corresponde a la tesis interpretativa que a la época mantenía la SEC respecto de la R 10b-5 SEC como un estándar de posesión (infra, sección 3.3). La doctrina entiende que la formulación de la prohibición hace irrelevante la motivación del acusado, pero se muestra vacilante a la hora de admitir que la imposición de responsabilidad penal por infracción a la R 14e-3(a) SEC pueda prescindir del dolo (scienter) propio del fraude, por lo que debería interpretarse en el sentido de exigir "algún requisito motivacional" ${ }^{\prime \prime}$.

En todo caso, junto con establecer la prohibición de operación en posesión de información no divulgada relativa a una tender offer, la SEC también estableció excepciones a la prohibición:

(i) la $\mathrm{R}$ 14e-3(b) SEC exceptúa de la prohibición a personas jurídicas que prestan servicios múltiples de asesoría financiera, siempre que satisfagan dos condiciones: (1) que las personas naturales que actúan por ella realizando la operación no hayan conocido la información, y (2) que la persona jurídica haya implementado políticas y procedimientos razonables para asegurar que las decisiones individuales de inversión no violen la prohibición $^{68}$;

(ii) la R 14e-3(c) SEC exceptúa de la prohibición a dos clases de operaciones: (1) las realizadas por un intermediario u otro agente en representación de una persona que formula una oferta, y (2) las ventas efectuadas por cualquiera a la persona oferente ${ }^{69}$.

\subsection{La distinción entre uso y posesión a fines del siglo $\mathrm{Xx}^{70}$.}

14e-3 in United States v. O'Hagan", Washington \& Lee Law Review $\mathrm{n}^{\circ} 55$ (1998), pp. 199-246; LANGEVOORT, Insider Trading, cit. nota $\mathrm{n}^{\circ}$ 50, $§ 7: 10$; WANG/STEINBERG, Insider Trading, cit. nota $\mathrm{n}^{\circ}$ 50, § 9.3; STEINBERG, Securities Regulation, cit. nota ${ }^{\circ}$ 50, § 3.08 .

${ }^{67}$ STEINBERG, Securities Regulation, cit. nota $\mathrm{n}^{\circ} 50, \S 3.08$; LANGEVOORT, Insider Trading, cit. nota ${ }^{\circ}$ $50, \S 7: 4$.

68 "'(b) A person other than a natural person shall not violate paragraph (a) of this section if such person shows that: / (1) The individual(s) making the investment decision on behalf of such person to purchase or sell any security described in paragraph (a) of this section or to cause any such security to be purchased or sold by or on behalf of others did not know the material, nonpublic information; and / (2) Such person had implemented one or a combination of policies and procedures, reasonable under the circumstances, taking into consideration the nature of the person's business, to ensure that individual(s) making investment decision(s) would not violate paragraph (a) of this section, which policies and procedures may include, but are not limited to, (i) those which restrict any purchase, sale and causing any purchase and sale of any such security or (ii) those which prevent such individual(s) from knowing such information." Disponible en loc. cit. supra nota 62.

69 “c) Notwithstanding anything in paragraph (a) of this section to contrary, the following transactions shall not be violations of paragraph (a) of this section: / (1) Purchase(s) of any security described in paragraph (a) of this section by a broker or by another agent on behalf of an offering person; or / (2) Sale(s) by any person of any security described in paragraph (a) of this section to the offering person." Disponible en loc. cit. supra nota 102.

${ }^{70}$ STEINBERG, Securities Regulation, cit. nota $\mathrm{n}^{\circ}$ 50, § 3.06[7]; LANGEVOORT, Insider Trading, cit. nota $\mathrm{n}^{\circ} 50, \S 3: 13$ y 3:14; WANG/STEINBERG, Insider Trading, cit. nota $\mathrm{n}^{\circ}$ 50, $\S 4.4 .5$; HAZEN, Treatise, cit. nota $\mathrm{n}^{\circ}$ 50, § 12.17[3]; HoRwICH, Allan, "The Origin, Application, Validity, and Potential Misuse of Rule 10b5-1”, The Business Lawyer n 62 (2007), pp. 913-954; FRIED, "Insider abstention”, cit. nota ${ }^{\circ} 6$. 
Polít. crim. Vol. 12, № 23 (Julio 2017), Art. 13, pp. 453-532.

[http://www.politicacriminal.cl/Vol_12/n_23/Vol12N23A13.pdf]

La interpretación de la R 10b-5 SEC como una prohibición del insider trading generó la cuestión, intensamente controvertida durante la última década del siglo XX, de si la infracción de la prohibición suponía que la operación se realizara en uso de la información privilegiada o si bastaba su realización en posesión de la información. El enfoque usual para el tratamiento de la cuestión es si el insider trading como forma de fraude supone un dolo de defraudar (scienter) ${ }^{71}$ que exige que la información sea la razón o motivo de la decisión de realizar la operación ${ }^{72}$. Pero tanto en la doctrina como al menos en el lenguaje de varias sentencias la cuestión también es tratada como un problema de causalidad psíquica $^{73}$.

La tesis defendida por la SEC en esta controversia consistió en interpretar la R 10b-5 SEC como una $\mathrm{POP}^{74}$. En el ámbito legislativo, la SEC obtuvo un reconocimiento de su tesis en 1984, con ocasión del establecimiento de la ITSA, que agregó la $§ 21$ (A) a la SEA para otorgar competencia a la SEC para obtener en tribunales una sanción pecuniaria (civil penalty) de hasta tres veces el monto del beneficio obtenido o la pérdida evitada. El supuesto de hecho de esa norma sancionatoria configura una infracción bajo el estándar estricto de posesión:

"Whenever it shall appear to the Commission that any person has violated any provision of this title or the rules or regulations thereunder by purchasing or selling a security while in possession of material nonpublic information (...),

La regla no tiene valor constitutivo para la configuración de la descripción, pues descansa en la R 10b5-1 inalterada, pero sí tiene peso interpretativo ${ }^{76}$.

En el plano judicial, la primera sentencia de una Corte de Apelaciones federal que trató extensamente la cuestión, en un caso de insider trading bajo la teoría de la misappropriation, United States v. Teicher, L.P. ${ }^{77}$, también validó la tesis interpretativa de la SEC. Aunque en el contexto de la sentencia la tesis de la Corte de Apelaciones del Segundo Circuito tuvo más bien el carácter de un dictum, pues en el caso se apreció amplia

\footnotetext{
${ }^{71}$ No existe definición legal del requisito de scienter, ni tampoco una clara definición jurisprudencial. La fórmula más utilizada por la doctrina y la jurisprudencia es la tesis de que la prueba de scienter bajo la $\mathrm{R} 10 \mathrm{~b}-$ 5 SEC requiere demostrar un estado mental que abarca la intención de engañar, manipular o defraudar: " $a$ mental state embracing intent to deceive, manipulate or defraud”: Ernst \& Ernst v. Hochfelder 425 U.S. 185 (1976), dejando abierta en su nota 12 la cuestión de si la imprudencia grave (recklessness) puede excepcionalmente satisfacer el requisito de scienter.

${ }^{72}$ Así, LANGEVOORT, Insider Trading, cit. nota $\mathrm{n}^{\circ}$ 50, loc. cit. supra nota $\mathrm{n}^{\circ} 70$.

${ }^{73}$ Así, HAZEN, Treatise, cit. nota $\mathrm{n}^{\circ} 50$, loc. cit. supra nota $\mathrm{n}^{\circ} 70$.

74 Aunque en su litigación en un caso de 1970 la SEC identificó como elemento del insider trading que la información poseída fuera un factor en la decisión del insider, su posición a fines del siglo XX fue consistente. Al respecto, NAGY, Donna M., "The 'Possession vs. Use' Debate in the Context of Securities Trading by Traditional Insiders: Why Silence Can Never be Golden”, University of Cincinnatti Law Review $\mathrm{n}^{\circ}$ 67. (1999), pp. 1129-1200, p. 1147-1152.

${ }^{75}$ Insider Trading Sanctions Act of 1984, en: 15 U.S. 78-u-1, con posteriores modificaciones. Disponible en: http://uscode.house.gov/view.xhtml?req=78u-

$1 \& \mathrm{f}=$ treesort $\& \mathrm{fq}=$ true $\&$ num $=11 \& \mathrm{hl}=$ true \&edition=prelim \& granuleId=USC-prelim-title15-section78u-1 (última consulta: 25.11.2016)

${ }^{76}$ LANGEVOORT, Insider Trading, cit. nota $\mathrm{n}^{\circ} 50$, loc. cit. supra nota $^{\circ} 70$.

77 987 F.2d 112, (1993), certiorari denegado 510 U.S. 976 (1993).
} 
BASCUÑÁN, Antonio. "Posesión, uso y explotación de la información privilegiada como elementos del insider trading en el derecho comparado del mercado de valores".

evidencia del uso de la información, ha permanecido como el locus clásico del estándar estricto de posesión:

“[A] 'knowing possession' standard has the attribute of simplicity. It recognizes that one who trades while knowingly possessing material inside information has an informational advantage over other traders. Because the advantage is in the form of information, it exists in the mind of the trader. Unlike a loaded weapon which may stand ready but unused, material information cannot lay idle in the human brain. The individual with such information may decide to trade upon that information, to alter a previously decided-upon transaction, to continue with a previously planned transaction even though publicly available information would now suggest otherwise, or simply to do nothing. In our increasingly sophisticated securities markets, where subtle shifts in strategy can produce dramatic results, it would be a mistake to think of such decisions as merely binary choices--to buy or to sell.

As a matter of policy then, a requirement of a causal connection between the information and the trade could frustrate attempts to distinguish between legitimate trades and those conducted in connection with inside information" ${ }^{\text {, }}$.

No obstante este reconocimiento, el lenguaje empleado en United States v. O'Hagan ${ }^{79}$, la sentencia de la USSC que validó la teoría de la misappropriation, no fue consistente con el estándar estricto de posesión, sino más bien con un estándar de uso. Reiteradamente la Corte Suprema describe en esa sentencia el comportamiento constitutivo de infracción a la $\mathrm{R}$ 10b-5 SEC como una operación "sobre la base de" (on the basis of) información privilegiada. Incluso sostuvo en un pasaje que el fraude fiduciario no se encuentra consumado cuando se obtiene la información confidencial, sino "cuando se usa esa información" para comprar o vender valores ${ }^{80}$. Es cierto que la Corte Suprema no se pronunció específicamente sobre esta cuestión en ese caso, por lo que sus afirmaciones sólo tienen el carácter de dicta. Pero un año más tarde sí lo hicieron otros tribunales federales, en ese preciso sentido. En SEC v. Adler ${ }^{81}$ la Corte de Apelaciones del Undécimo Circuito rechazó el estándar estricto de posesión y sostuvo que la R 10b-5 sólo es infringida cuando la información es efectivamente usada por el insider. Con todo, la sentencia no postuló un estándar estricto de uso, pues reconoció que la prueba de la posesión constituye una presunción fuerte o robusta de uso. Este estándar modificado de uso basta, según la Corte, para satisfacer las consideraciones de la SEC acerca de la dificultad de probar la conexión entre el conocimiento de la información y la operación. En sus palabras:

"We view the choice between the SEC's knowing possession test and the use test advocated by Pegram as a difficult and close question of first impression. It is apparent from the foregoing discussion that there is no definitive guidance on this issue from the Supreme Court. However, we believe that Supreme Court dicta and the lower court precedent suggest that the use test is the appropriate test. The strongest argument that has been articulated in support of the knowing possession test is that a strict use test

\footnotetext{
${ }^{78}$ Sentencia cit. nota $\mathrm{n}^{\circ} 77 \S 55,56$.

${ }^{79} 521$ U.S. 642 (1997).

80 " $[\mathrm{T}]$ he fiduciary's fraud is consummated, not when the fiduciary gains the confidential information, but when, without disclosure to his principal, he uses the information to purchase or sell securities." (Op. cit., 656).

${ }^{81} 137$ F 3rd 1325 (11th Cir. 1998), certiorari denegado_525 U.S. 1071 (1999).
} 
Polít. crim. Vol. 12, No 23 (Julio 2017), Art. 13, pp. 453-532.

[http://www.politicacriminal.cl/Vol_12/n_23/Vol12N23A13.pdf]

would pose serious difficulties of proof for the SEC. It is true that it often would be difficult for the SEC to have to prove that an insider used the inside information, i.e., that the inside information has a causal connection to a particular trade. However, we believe that the SEC's problems in this regard are sufficiently alleviated by the inference of use that arises from the fact that an insider traded while in possession of inside information.

We believe that the use test best comports with precedent and Congressional intent, and that mere knowing possession--i.e., proof that an insider traded while in possession of material nonpublic information--is not a per se violation. However, when an insider trades while in possession of material nonpublic information, a strong inference arises that such information was used by the insider in trading. The insider can attempt to rebut the inference by adducing evidence that there was no causal connection between the information and the trade--i.e., that the information was not used. The fact finder would then weigh all of the evidence and make a finding of fact as to whether the inside information was used" 82 .

Esta concesión judicial a la SEC fue rechazada tratándose de juicios criminales por la Corte de Apelaciones del Noveno Circuito en United States v. Smith ${ }^{83}$. Esta Corte sigue a Adler en cuanto a reconocer al estándar de uso como el criterio requerido por la R 10b-5 SEC, sosteniendo además que el estándar estricto de posesión es inaceptablemente sobreinclusivo $^{84}$. Pero restringe la validez de la presunción postulada por Adler, esto es, el estándar modificado de uso, al establecimiento de la responsabilidad civil por la infracción. Desde el punto de vista de la Corte, semejante presunción no es procedente en juicios criminales. Ciertamente la acusación puede hacer valer prueba circunstancial para demostrar el abuso de la información, pero no puede pretender invertir la carga de la prueba mediante una presunción ${ }^{85}$.

\footnotetext{
${ }^{82}$ Sentencia cit. nota $\mathrm{n}^{\circ} 81, \S \S 41,42$

${ }^{83} 155$ F. $3^{\text {rd }} 1051$ ( $9^{\text {th }}$ Cir. 1998).

84 "Like our colleagues on the Eleventh Circuit, we are concerned that the SEC's "knowing possession" standard would not be--indeed, could not be--strictly limited to those situations actually involving intentional fraud. For instance, an investor who has a preexisting plan to trade, and who carries through with that plan after coming into possession of material nonpublic information, does not intend to defraud or deceive; he simply intends to implement his pre-possession financial strategy." (Sentencia cit. nota n ${ }^{\circ} 83, \S 67$ ).

85 "Of course, we deal here with a criminal prosecution, not a civil enforcement proceeding, as was the situation in Adler. We are therefore not at liberty, as was the Adler court, to establish an evidentiary presumption that gives rise to an inference of use. See Sandstrom v. Montana, 442 U.S. 510, 524, 99 S.Ct. 2450, 61 L.Ed.2d 39 (1979) ('A presumption which, although not conclusive, had the effect of shifting the burden of persuasion to the defendant, would have suffered from [constitutional] infirmities.'). / We nonetheless adhere to our view that Rule 10b-5 entails a 'use' requirement. We appreciate that a 'use' requirement renders criminal prosecutions marginally more difficult for the government to prove. The difficulties, however, are by no means insuperable. (...) Any number of types of circumstantial evidence might be relevant to the causation issue. Suppose, for instance, that an individual who has never before invested comes into possession of material nonpublic information and the very next day invests a significant sum of money in substantially out-of-the-money call options. We are confident that the government would have little trouble demonstrating 'use' in such a situation, or in other situations in which unique trading patterns or unusually large trading quantities suggest that an investor had used inside information." (Op. cit. $\S \S 70-71)$.
} 
BASCUÑÁN, Antonio. "Posesión, uso y explotación de la información privilegiada como elementos del insider trading en el derecho comparado del mercado de valores".

\subsection{La distinción entre uso y posesión bajo la Regla 10b5-1 SEC.}

Para poner fin a la controversia descrita en la sección anterior la SEC estableció la R 10b51 SEC el 24 de agosto de 2000. En la parte que es directamente relevante aquí -letras (a) y (b)- la regla es del siguiente tenor:

Trading "on the basis of" material nonpublic information in insider trading cases. Preliminary Note to $\$ 240.10 b 5-1$ : This provision defines when a purchase or sale constitutes trading "on the basis of" material nonpublic information in insider trading cases brought under Section 10(b) of the Act and Rule 10b-5 thereunder. The law of insider trading is otherwise defined by judicial opinions construing Rule 10b-5, and Rule 10b5-1 does not modify the scope of insider trading law in any other respect.

(a) General. The "manipulative and deceptive devices" prohibited by Section 10(b) of the Act (15 U.S.C. 78j) and §240.10b-5 thereunder include, among other things, the purchase or sale of a security of any issuer, on the basis of material nonpublic information about that security or issuer, in breach of a duty of trust or confidence that is owed directly, indirectly, or derivatively, to the issuer of that security or the shareholders of that issuer, or to any other person who is the source of the material nonpublic information.

(b) Definition of "on the basis of." Subject to the affirmative defenses in paragraph (c) of this section, a purchase or sale of a security of an issuer is "on the basis of" material nonpublic information about that security or issuer if the person making the purchase or sale was aware of the material nonpublic information when the person made the purchase or sale." 86

Como se puede apreciar, la SEC concede inicialmente que la $\mathrm{R} 10 \mathrm{~b}-5$ prohíbe operaciones sobre la base de información privilegiada, es decir, concede su interpretación como POU, pero inmediatamente reformula la infracción mediante una definición del uso como posesión consciente de la información, es decir, la concibe como POP. La SEC justificó esta reformulación de la regla siguiendo abiertamente a Teicher:

"In our view, the goals of insider trading prohibitions -protecting investors and the integrity of securities markets- are best accomplished by a standard closer to the 'knowing possession' standard. Whenever a person purchases or sells a security while aware of material nonpublic information that has been improperly obtained, that person has the type of unfair informational advantage over other participants in the market that insider trading law is designed to prevent. As a practical matter, in most situations it is highly doubtful that a person who knows inside information relevant to the value of a security can completely disregard that knowledge when making the decision to purchase or sell that security. In the words of the Second Circuit, 'material information cannot lay idle in the human brain.' Indeed, even if the trader could put forth purported reasons for trading other than awareness of the inside information, other traders in the market place would clearly perceive him or her to possess an unfair advantage." 87

\footnotetext{
${ }^{86} 17$ C.F.R. $\$ 240.10 b 5-1$. Disponible en:

http://www.ecfr.gov/cgibin/retrieveECFR?gp=\&SID=b938ac79d47d513584888e3c5b5921a7\&n=pt17.4.240\&r=PART\&ty=HTML\#s e17.4.240_110b5 61 (última consulta: 25.11.2016)

${ }^{87}$ Securities and Exchange Commission, Proposed Rule: Selective Disclosure and Insider Trading (17 CFR Parts 230, 240, 243, and 249). Release Nos. 33-7787, 34-42259, IC-24209, File No. S7-31-99- RIN 3235-
} 
Polít. crim. Vol. 12, No 23 (Julio 2017), Art. 13, pp. 453-532.

[http://www.politicacriminal.cl/Vol_12/n_23/Vol12N23A13.pdf]

El establecimiento de la R 10b5-1(b) SEC no ha resuelto todos los problemas que rodeaban la controversia uso vs. posesión en la prohibición del insider trading ${ }^{88}$. El sentido de la exigencia de conciencia (awareness) de la información al momento de la operación puede ir desde la obvia consideración de que la custodia de soportes sin conocer su contenido no es posesión de información hasta la consideración, enteramente problemática desde la perspectiva de la SEC, que la información deba "estar presente" en la deliberación que precede a la decisión de realizar la operación. La validez de la definición adoptada por la SEC en la regla (b) es también cuestionada, precisamente en atención a que el fundamento de la validez de la R 14e-3 SEC descansa, según la SEC y la Corte Suprema ${ }^{89}$, en la mayor competencia normativa que le concede la $\S 14(\mathrm{e})$ SEA en comparación con la competencia que le concede la $\S 10$ (b) SEA ${ }^{90}$. Dado que la $\S 10$ (b) SEA no concede a la SEC un poder normativo preventivo ("profiláctico") como el que concede la $\S 14(\mathrm{e})$ SEA, dado que la descripción del insider trading que establece la R 14e-3(a) SEC (operación en posesión de información) se entiende legítima por proceder de un poder normativo preventivo, y dado que la definición de operar "sobre la base de" información establecida en la R 10b5-1(b) es enteramente equivalente una descripción de la infracción como operación en posesión de la información, se tiene que la SEC estableció una regla que va más allá de su competencia normativa. La crítica en este sentido a la regulación de la SEC se expresa como reproche por haber eliminado el requisito de scienter de la infracción a la prohibición de insider trading $^{91}$. Así formulada la objeción no es certera, porque la R 10b5-1(b) no elimina toda exigencia de intencionalidad, como la SEC ha observado ${ }^{92}$. Lo que la regla elimina es la exigencia de una conexión de sentido entre el conocimiento de la información y la decisión de realizar la operación. Eso es precisamente lo que resulta cuestionable por falta de competencia $^{93}$.

AH82. III.A.1. Disponible en: http://www.sec.gov/rules/proposed/34-42259.htm (última consulta: 25.11.2016). La argumentación fue ratificada posteriormente por la SEC al momento de establecer la regulación: Final Rule: Selective Disclosure and Insider Trading (17 CFR Parts 240, 243, and 249). Release Nos. 33-7881, 34-43154, IC-24599, File No. S7-31-99. RIN 3235-AH82. III.A.1. Disponible en: http://www.sec.gov/rules/final/33-7881.htm (última consulta: 25.11.2016).

${ }^{88}$ SWANSON, Carol B., "Insider Trading Madness: Rule 10b5-I and the Death of Scienter", University of Kansas Law Review n 52 (2003), pp. 147-209; HORWICH, "The Origin", cit. nota n 70; LANGEVOORT, Insider Trading, cit. nota $\mathrm{n}^{\circ} 50, \S 3: 14$.

${ }^{89}$ Supra, nota ${ }^{\circ} 66$.

${ }^{90} \mathrm{La} \S 10 \mathrm{~b}$ SEA autoriza a la SEC a "prescribir [reglas y regulaciones] necesarias o apropiadas in el interés público o para la protección de inversionistas"; en cambio, la $\S 14$ e SEA la autoriza a "definir y prescribir [mediante reglas y regulaciones] razonablemente diseñadas para prevenir tales actos y prácticas".

${ }_{91}$ Naturalmente, si se interpreta el estándar de "awareness" de la información como su presencia en la deliberación que termina en la decisión de realizar la operación, desaparece el problema de la invalidez de la regla. Al respecto: WARNER, "Rethinking Trades", pp. 305 y ss.

92 "Some commenters stated that an awareness standard might eliminate the element of scienter from insider trading cases, contrary to the requirements of Section 10(b) of the Exchange Act, and that we therefore lack the authority to promulgate the rule. These comments misconstrue the intent and effect of the rule. As discussed in the Proposing Release and expressly stated in the Preliminary Note, Rule 10b5-1 is designed to address only the use/possession issue in insider trading cases under Rule 10b-5. The rule does not modify or address any other aspect of insider trading law, which has been established by case law. Scienter remains a necessary element for liability under Section 10(b) of the Exchange Act and Rule 10b-5 thereunder, and Rule 10b5-1 does not change this". (Final Rule...loc.cit. supra nota 127).

${ }^{93}$ DAVIS, Harry S. (ed.), Insider Trading Law and Compliance. New York: Practicing Law Institute, 2015, pp. 124-125; BAINBRIDGE, Stephen M. (2014), Insider Trading Law and Policy. St. Paul, MN: West Publishing, 2014, p. 74. 
BASCUÑÁN, Antonio. "Posesión, uso y explotación de la información privilegiada como elementos del insider trading en el derecho comparado del mercado de valores".

Como sea, la SEC reconoció al momento de establecer la R 10b5-1(a) que la definición de la infracción conforme a un estándar de posesión resultaba sobreinclusiva en algunos casos. Pero según la SEC ese problema no justificaba el empleo de un estándar moderado de uso, sino la formulación de una POP junto con la adopción de un estándar moderado de posesión. El remedio para ese problema de la sobreinclusión según la SEC es la previsión de excepciones en la misma regulación:

"[W]e recognize that an absolute standard based on knowing possession, or awareness, could be overbroad in some respects. The new rule attempts to balance these considerations by means of a general rule based on 'awareness' of the material nonpublic information, with several carefully enumerated affirmative defenses. This approach will better enable insiders and issuers to conduct themselves in accordance with the law". 94

Las defensas reconocidas por la R 10b5-1(c) son de dos clases. La R 10b5-1(c)(1) SEC establece para cualquier persona la defensa del defensa de la orden o plan previo, que más adelante se examina (infra, sección 2.5.1). La R10b5-1(c)(2) establece una defensa de la persona jurídica que otorga servicios múltiples de asesoría financiera, semejante a (tomada de) la defensa establecida por la misma SEC en 1980 para el contexto de las tender offers en la Regla 14e-3(c) SEC (supra, sección 2.2) ${ }^{95}$.

El problema fundamental que plantea esta solución de la SEC se encuentra en su pretensión de que estas reglas constituyan "defensas exclusivas", esto es, que la R 10b5-1 excluya la pertinencia o relevancia de cualquier otro argumento que pueda invocar una persona para negar que haya infringido la prohibición de insider trading, si es que realizó una operación con conocimiento de información privilegiada. Es claro que esta es la concepción que la

\footnotetext{
${ }^{94}$ Ibídem, nota ${ }^{\circ} 87$.

95 “(2) A person other than a natural person also may demonstrate that a purchase or sale of securities is not "on the basis of" material nonpublic information if the person demonstrates that: / (i) The individual making the investment decision on behalf of the person to purchase or sell the securities was not aware of the information; and / (ii) The person had implemented reasonable policies and procedures, taking into consideration the nature of the person's business, to ensure that individuals making investment decisions would not violate the laws prohibiting trading on the basis of material nonpublic information. These policies and procedures may include those that restrict any purchase, sale, and causing any purchase or sale of any security as to which the person has material nonpublic information, or those that prevent such individuals from becoming aware of such information." Disponible en loc. cit. supra nota $\mathrm{n}^{\circ} 59$.
} 
Polít. crim. Vol. 12, № 23 (Julio 2017), Art. 13, pp. 453-532.

[http://www.politicacriminal.cl/Vol_12/n_23/Vol12N23A13.pdf]

propia SEC tiene de su regulación ${ }^{96}$. La doctrina considera sin embargo que esta pretensión no es legítima, sobre todo en juicios criminales ${ }^{97}$.

\subsection{La defensa del plan previo.}

Como se ha visto reiteradamente, el caso del inversionista que imparte una orden o diseña un plan de operaciones antes de poseer información privilegiada y posteriormente deja que la operación sea realizada conforme a esa orden o plan, a pesar de poseer información privilegiada al momento de su realización, es un ejemplo recurrente en la doctrina y la jurisprudencia estadounidense de operación en posesión de información privilegiada que no requiera ser objeto de una prohibición. Este reconocimiento ha sido pleno en el contexto de la prohibición general de insider trading atribuida a la R 10b-5 SEC. En contraste, existe un notorio silencio en relación con la defensa del plan previo en el contexto de la prohibición especial de insider trading en tender offers, establecida en la R 14e-3(a) SEC. Eso exige un análisis por separado.

\subsubsection{Frente a cargos bajo la R 10b-5 SEC.}

En United States v. Smith la Corte de Apelaciones del Noveno Circuito hizo valer precisamente el caso del plan previo para demostrar la razonabilidad del estándar de uso por comparación con el estándar de posesión:

"[A]n investor who has a preexisting plan to trade, and who carries through with that plan after coming into possession of material nonpublic information, does not intend to defraud or deceive; he simply intends to implement his pre-possession financial strategy. The SEC suggests that the requisite intent to defraud is inherent in the act of trading while in possession of inside information. (...)

\footnotetext{
96 "While many of the commenters on Rule 10b5-1 supported our goals of providing greater clarity in the area of insider trading law, some suggested alternative approaches to achieving these goals. In that regard, a common comment was that the rule should not rely on exclusive affirmative defenses. Commenters suggested that we should either redesignate the affirmative defenses as non-exclusive safe harbors or add a catch-all defense to allow a defendant to show that he or she did not use the information. / We believe the approach we proposed is appropriate. In our view, adding a catch-all defense or redesignating the affirmative defenses as non-exclusive safe harbors would effectively negate the clarity and certainty that the rule attempts to provide. Because we believe that an awareness standard better serves the goals of insider trading law, the rule as adopted employs an awareness standard with carefully enumerated affirmative defenses. As discussed below, however, we have somewhat modified these defenses in response to comments that they were too narrow or rigid, and that additional ones were necessary. (Ibídem).

${ }^{97}$ SWANSON, "Insider Trading", cit. nota n ${ }^{\circ} 88$, p. 200 y s.; HORWICH, "The Origin", cit. nota $n^{\circ} 70$, p. 949: "While no parallel situation has been found, where an agency has adopted a rule construing a statute and in turn has specified that certain conduct will constitute a defense to a charge of violating that statute and no other conduct can rebut the charge, the foregoing analysis strongly suggests that the SEC's effort to specify exclusive defenses or an exhaustive list of defenses is not valid. As a result, a defendant or respondent in either a criminal case or civil action charging unlawful insider trading should be allowed to rebut any showing of use (or proof of trading while 'aware') without being limited to the three affirmative defenses set forth in Rule 10b5-1". También LANGEVOORT, Insider Trading, cit. nota $n^{\circ} 50, \S 3: 14$, citando jurisprudencia posterior a la R 10b5-1 SEC que prescinde de ella y se sujeta al estándar de uso de Adler y Smith. Previsiblemente, la Corte de Apelaciones del Segundo Circuito ha aplicado sin reparos la R 10b5-1 SEC (LANGEVOORT, Insider Trading, cit. nota $\mathrm{n}^{\circ}$ 50, loc. cit.; DAVIS, Insider Trading, cit. nota 93, pp. 124126).
} 
BASCUÑÁN, Antonio. "Posesión, uso y explotación de la información privilegiada como elementos del insider trading en el derecho comparado del mercado de valores".

The SEC's position, however, rests upon a faulty premise. The persons with whom a hypothetical insider trades are not at a 'disadvantage' at all provided the insider does not 'use' the information to which he is privy. That is to say, if the insider merely possesses and does not use, the two parties are trading on a level playing field; if the insider merely possesses and does not use, both individuals are 'making their decisions on the basis of incomplete information.' It is the insider's use, not his possession, that gives rise to an informational advantage and the requisite intent to defraud". ${ }^{98}$

Como lo ha puesto de manifiesto un autor, ${ }^{99}$ este argumento supone que el fundamento de la prohibición sea la igualdad de oportunidades en el mercado de valores. Eso permite advertir que el estándar de posesión - la POP - resulta más consistente con la teoría clásica impuesta por la Corte Suprema a la SEC: en la medida en que el insider tiene un deber fiduciario para con su contraparte en la operación tal que o bien le comunica la información privilegiada que posee o se abstiene de transar con ella es la infracción de este deber y no un abuso adicional lo que fundamenta la ilicitud. Pero esa no es la consideración de la SEC, que siempre ha sido reacia a aceptar un deber fiduciario especial preexistente como fundamento de la prohibición. Como se vio antes, la SEC consideró que el estándar de posesión respondía de mejor modo a la consideración de la evitación de asimetrías informativas injustas, siempre que se exceptuara de su alcance los casos en que esa asimetría no afectaba la confianza en la integridad del mercado. Eso la llevó a establecer la defensa del plan previo en la R 10b5-1(c)(1), en los siguientes términos:

“(c) Affirmative defenses. (1)(i) Subject to paragraph (c)(1)(ii) of this section, a person's purchase or sale is not "on the basis of" material nonpublic information if the person making the purchase or sale demonstrates that:

(A) Before becoming aware of the information, the person had:

(1) Entered into a binding contract to purchase or sell the security,

(2) Instructed another person to purchase or sell the security for the instructing person's account, or

(3) Adopted a written plan for trading securities;

(B) The contract, instruction, or plan described in paragraph (c)(1)(i)(A) of this Section:

(1) Specified the amount of securities to be purchased or sold and the price at which and the date on which the securities were to be purchased or sold;

(2) Included a written formula or algorithm, or computer program, for determining the amount of securities to be purchased or sold and the price at which and the date on which the securities were to be purchased or sold; or

(3) Did not permit the person to exercise any subsequent influence over how, when, or whether to effect purchases or sales; provided, in addition, that any other person who, pursuant to the contract, instruction, or plan, did exercise such influence must not have been aware of the material nonpublic information when doing so; and

(C) The purchase or sale that occurred was pursuant to the contract, instruction, or plan. A purchase or sale is not "pursuant to a contract, instruction, or plan" if, among other things, the person who entered into the contract, instruction, or plan altered or deviated from the contract, instruction, or plan to purchase or sell securities (whether by changing the amount, price, or timing of the purchase or sale), or entered into or

\footnotetext{
98155 F.3d 1051, $\$$ 68-69 (1998).

${ }^{99}$ LANGEVOORT, Insider Trading, cit. nota $n^{\circ} 50, \S 3: 13$.
} 
Polít. crim. Vol. 12, No 23 (Julio 2017), Art. 13, pp. 453-532.

[http://www.politicacriminal.cl/Vol_12/n_23/Vol12N23A13.pdf]

altered a corresponding or hedging transaction or position with respect to those securities.

(ii) Paragraph (c)(1)(i) of this section is applicable only when the contract, instruction, or plan to purchase or sell securities was given or entered into in good faith and not as part of a plan or scheme to evade the prohibitions of this section.

(iii) This paragraph (c)(1)(iii) defines certain terms as used in paragraph (c) of this Section.

(A) Amount. "Amount" means either a specified number of shares or other securities or a specified dollar value of securities.

(B) Price. "Price" means the market price on a particular date or a limit price, or a particular dollar price.

(C) Date. "Date" means, in the case of a market order, the specific day of the year on which the order is to be executed (or as soon thereafter as is practicable under ordinary principles of best execution). "Date" means, in the case of a limit order, a day of the year on which the limit order is in force". ${ }^{100}$

La detallada regulación establecida por la SEC no quita que permanezcan importantes dudas acerca del estatus de las operaciones realizadas conforme a órdenes previas. El primero concierne a las órdenes que no satisfacen todos los requisitos exigidos por la letra (B) de la regla. Respecto de este problema vale lo dicho arriba (supra, sección 3.4): la SEC pretende que esas operaciones infringen la prohibición tal como es definida por la $\mathrm{R} 10 \mathrm{~b} 5$ 1(b); esa pretensión no goza de reconocimiento generalizado en la doctrina ni en la jurisprudencia.

El segundo problema concierne al estatus de la cancelación de órdenes efectuada en uso de la información. Es decir, al caso en que el insider imparte la orden antes de poseer información privilegiada y una vez que entra en posesión de información privilegiada que es inconsistente con la ejecución de esa orden la cancela. La doctrina estadounidense considera que la cancelación de órdenes tiene el mismo estatus que la abstención en general (insider non trading): no infringe la prohibición de insider trading. Esto es así porque en cualquiera de sus formulaciones la prohibición requiere una conexión con compras o ventas de valores ${ }^{101}$. Como se dijo en la primera sección, esta tesis implica para el insider un margen de aprovechamiento estratégico de la información privilegiada: si bien no puede usarla para realizar operaciones, puede diseñar operaciones especulativas y luego corregirlas mediante su cancelación total o parcial. La SEC no ha controvertido la licitud de la cancelación de las órdenes, pero ha sostenido que el hecho de la cancelación puede impedir la eficacia de la defensa del plan previo respecto de otras compras o ventas, en el sentido de demostrar la ausencia de buena fe requerida por la Regla 10b5-1(1)(ii) ${ }^{102}$.

\footnotetext{
${ }^{100}$ Supra, nota $\mathrm{n}^{\circ}$ 86. La SEC provee además directrices interpretativas para la $\mathrm{R} 10 \mathrm{~b} 5-1 \mathrm{SEC}$. Al respecto, Exchange Act Rules. Last Update: February 13, 2012. Section 120. Manipulative and Deceptive Devices and Contrivances: Rule 10b5-1. Disponible en: http://www.sec.gov/divisions/corpfin/guidance/exchangeactrules-interps.htm (última consulta: 25.11.2016).

${ }^{101}$ LANGEVOORT, Insider Trading, cit. nota $\mathrm{n}^{\circ} 50, \S 3: 14 ; \S 3: 16$. La tesis se basa en un precedente de la USSC: Blue Chip Stamps v. Manor Drug Stores, 421 U.S. 723 (1975).

102 DAVIS, Insider Trading, cit. nota $\mathrm{n}^{\circ}$ 93, p. 131; Division of Corporation Finance, Manual of Publicly Available Telephone Interpretations. Fourth Supplement (Includes Interpretations Issued May 2001, December 2000, and October 2000). Rule 10b5-1. Written Trading Plans, Nr. 15. After the written trading plan described in Q\&A 11(a) has been in effect for several months, the person terminates the selling plan by
} 
BASCUÑÁN, Antonio. "Posesión, uso y explotación de la información privilegiada como elementos del insider trading en el derecho comparado del mercado de valores".

\subsubsection{Frente a cargos bajo la R 14e-3(a) SEC.}

La cuestión de si la R 14e-3(a), que explícitamente describe la infracción de insider trading conforme al estándar de la posesión, es decir, formula la prohibición expresamente como $\mathrm{POP}^{103}$, responde al modelo de un estándar estricto o modificado de posesión tratándose de las operaciones en ejecución de un plan previo es de respuesta incierta.

En principio, es evidente que la defensa afirmativa de la $\mathrm{R}$ 10b5-1(c) conforme a sus propios términos no opera sino respecto de cargos por infracción de la R 10b-5 SEC. En principio, también es evidente que la SEC no estableció para la R 14e-3(a) una excepción de plan previo. Eso contrasta con la excepción para la persona jurídica que presta servicios múltiples, que es común a ambas regulaciones (supra, 2.2 y 2.4). De los hechos anteriores puede derivarse la conclusión de que, en la terminología estadounidense, la R 14e-3(a) SEC prescinde del scienter como elemento de la infracción. Eso ha sido afirmado explícitamente por la Corte de Distrito del Distrito del Sur de Nueva York en Caleb \& Co. v. E.I. DuPont de Nemours \& Co. $^{104}$ :

calling the broker and canceling the limit order. / (a) Does the act of terminating a plan while aware of material nonpublic information result in liability under Section 10(b) and Rule 10b-5? / No. Section 10(b) and Rule 10b-5 apply "in connection with the purchase or sale of any security." Thus, a purchase or sale of a security must be present for liability to attach. See Blue Chip Stamps v. Manor Drug Stores, 421 U.S. 723 (1975). / (b) Does termination of a plan affect the availability of the Rule 10b5-1(c) defense for prior plan transactions? Does canceling one or more plan transactions affect the availability of the Rule 10b5-1(c) defense for prior plan transactions? / Termination of a plan, or the cancellation of one or more plan transactions, could affect the availability of the Rule 10b5-1(c) defense for prior plan transactions if it calls into question whether the plan was "entered into in good faith and not as part of a plan or scheme to evade" the insider trading rules within the meaning of Rule 10b5-1(c)(1)(ii). The absence of good faith or presence of a scheme to evade would eliminate the Rule 10b5-1(c) defense for prior transactions under the plan. / (c) Does canceling one or more plan transactions affect the availability of the Rule 10b5-1(c) defense for future plan transactions? / The cancellation of one or more plan transactions would be an alteration or deviation from the plan, which would terminate that plan. The Rule 10b5-1(c) defense would be available for transactions following the alteration only if the transactions were pursuant to a new contract, instruction or plan that satisfies the requirements of Rule 10b5-1(c). See Release 33-7881 at n. 111 and Answer 14, above.". Disponible en: http://www.sec.gov/interps/telephone/phonesupplement4.htm (última consulta: 25.11.2016).

${ }^{103}$ El reconocimiento de este rasgo, evidente conforme al tenor literal de la disposición es extendido en la jurisprudencia, tanto en la que interpreta la R 10b-5 como una POP, como en la que la interpreta como una POU. U.S. v. Teicher, 987 F. 2d 112 (1993): "Rule 14e-3, which prohibits fraud in connection with tender offers explicitly provides a 'knowing possession' standard" (§ 52). U.S. v. Adler, 37 F.3d 1325 (1998): "The SEC has had ample opportunity to adopt a rule or amend Rule $10 \mathrm{~b}-5$ so as to provide that a trade with knowing possession of material nonpublic information triggers insider trading liability. However, although the SEC has adopted such a rule in the context of tender offers" (\$45). La subordinación de la R 14e-3(a) al estándar de posesión fue afirmado por la propia SEC al momento de su establecimiento: "The Commission has previously expressed and continues to have serious concerns about trading by persons in possession of material, nonpublic information relating to a tender offer. This practice results in unfair disparities in market information and market disruption. (Securities Exchange Act Release No. 17120, September 4, 1980, citado conforme a HELLER, Harry, "Chiarella, SEC Rule 14e-3 and Dirks: 'Fairness' versus Economic Theory", The Business Lawyer n 37 [1982], pp. 517-558, 545).

104599 F. Supp. 1468, 1473 (1984). Para un análisis de la sentencia en el contexto de la jurisprudencia previa, que no distinguía mayormente entre los requisitos de la R 10b-5 SEC y la R 14e-3(a) SEC, RYAN, Laura, "Comment: Rule 14e-3's Disclosure-or-Abstain Rule and its Validity Under Section 14(e)", University of Cincinnati Law Review n 60 (1991), pp. 449-493, pp. 471 y ss. 
Polít. crim. Vol. 12, No 23 (Julio 2017), Art. 13, pp. 453-532.

[http://www.politicacriminal.cl/Vol_12/n_23/Vol12N23A13.pdf]

"[T]he relationship between Rule 14e-1(c) and $\S 14(\mathrm{e})$ differs from that between Rule $10 \mathrm{~b}-5$ and $\S 10$ (b). Rule 10b-5 proscribes manipulative, deceptive, and fraudulent acts generally, just as does $\S 10(\mathrm{~b})$. The courts, in defining these terms, have necessarily added clarity to these general proscriptions such that they have become virtual "terms of art." Ernst \& Ernst, supra, 425 U.S. at 199, 96 S.Ct. at 1384. However, section 14(e) gave the Commission authority, "by rules and regulations [to] define, and prescribe means reasonably designed to prevent, such acts and practices as are fraudulent, deceptive, or manipulative." Within this authority, the Commission drafted the prohibitions defined by Rule 14e. Rather than rely on a rule which prohibits fraudulent activity generally, while leaving the courts to define the scope of that term as the Commission did with $10 \mathrm{~b}-5$, the Commission exercised its authority to create specific rule and regulations which are reasonably designed to prevent fraud. In doing so the Commission created an absolute prohibition that "no person who makes a tender offer shall' fail to pay promptly. While Rule 10b-5 strikes only at acts which are themselves fraudulent or deceptive, as defined by the courts, the rules issued pursuant to $\S 14(\mathrm{e})$ are reasonable exercises of administrative authority designed to prevent fraud in tender offers. Thus, 14e-1(a) prohibits any person from keeping a tender offer open for less than twenty business days, not because every tender offer kept open for less than twenty days would involve fraud, but because the Commission can reasonably exercise its duty to prevent fraud by forbidding that any tender offer be kept open for less than twenty days. Similarly, rule $14 \mathrm{e}-1$ (c)'s requirement that no person shall fail to pay promptly creates liability even where no scienter is alleged or proven, because the Commission, in a reasonable exercise of authority, believed that prohibiting all such imprompt payments would prevent fraud within the meaning of the Act". ${ }^{105}$

Si bien la afirmación constituye un dictum, pues el caso se refería a la aplicación de otra prohibición relativa a las tender offers, la contenida en la $\mathrm{R} 14 \mathrm{e}-1$ (a) SEC, ella expresa claramente la idea de que la $\mathrm{R}$ 14e-3(a) SEC no requiere una conexión de sentido entre la información poseída y la operación realizada como parte de la intención de defraudar ${ }^{106}$. Así entendida la prohibición, quien entra en posesión de información relativa a una tender offer que satisface las condiciones de la $\mathrm{R} 14 \mathrm{e}-3$ (a) no podría realizar una operación, ni siquiera por intermedio de otro. Dada la ausencia de una defensa de plan previo, esta inhibición alcanzaría al que ha impartido una orden previa a la posesión de la información ${ }^{107}$. Algunos autores deducen de lo anterior que la única manera de cumplir con la prohibición sería cancelando la orden ${ }^{108}$.

\footnotetext{
${ }^{105}$ Id. p. 1473.

${ }^{106}$ STEINBERG, Securities Regulation, cit. nota $n^{\circ} 50, \S 3.08$, p. 3-76 nota 10 señala como sentencia en esta misma línea a SEC v. Falbo 14 F. Supp 2d 508 (1998), que afirma que el estándar bajo la R 14e-3(a) es "mucho más leve" que bajo la R 10b-5 SEC (p. 527). Pero ese estándar se refiere al conocimiento de la calidad de privilegiada de la información.

107 FREED, Merrill A., SCHRAIBMAN, Steven E., "A Checklist for Officers and Directors Trading in Company Stock, Insights $\mathrm{n}^{\circ} 15$ (2001), pp. 16-20, p. 17: "[T]he plan offers only affirmative defense to a charge of insider trading under Rule 10b-5 and does not provide protection against other matters, including: (...) / Claims based on Rule 14e-3 under the Exchange Act, which prohibits trading by personas who are in possession of material inside information relating to a tender offer".

${ }^{108}$ HORWICH, Allan, KLEIN, Andrew M. (Schiff Hardin LLP), A Primer on SEC Rule 10b5-1: Affirmative Defenses For Insider Trading. November 10, 2003. Disponible en:

http://www.schiffhardin.com/Templates/Media/files/archive/binary/klein-primer_sec10b5-1.pdf: "Rule 10b51 provides a defense only to a claim of a violation of Rule 10b-5. There is also a prohibition on insider trading — buying or selling — in Rule $14 \mathrm{e}-3$, when a person is in possession of material nonpublic information
} 
BASCUÑÁN, Antonio. "Posesión, uso y explotación de la información privilegiada como elementos del insider trading en el derecho comparado del mercado de valores".

Por otra parte, la jurisprudencia federal estadounidense conoce casos en que se ha afirmado que la imputación de infracción a la Regla 14e-3(a) SEC requiere la prueba de scienter en los mismos términos que la imputación de una infracción a la Regla 10b-5 SEC. Así, en Burlington Industries, Inc. v. Edelman ${ }^{109}$, la Corte de Distrito del Distrito Medio de Carolina del Norte, División Greensboro, sostuvo en 1987 que un demandante particular debía probar scienter dentro de los elementos de la R 14e-3(a), siguiendo a Adler ${ }^{110}$. De modo análogo, en SEC v. Mayhew ${ }^{111}$, la Corte de Distrito del Distrito de Connecticut identificó en 1995 entre los elementos de juicio que justificaban la imposición de responsabilidad por infracción a la $\mathrm{R}$ 14e-3(a) SEC el hecho de que la información privilegiada hubiera motivado la compra de valores, rechazando por falta de persuasividad y no por improcedencia la pretendida justificación de la defensa basada en justificar la compra por razones distintas de la información ${ }^{112}$.

\subsection{Excurso: la prohibición de short swing profit (§ 16b SEA $)^{113}$.}

La $\S 16$ b SEA $^{114}$ es la única regla deliberadamente establecida por el legislador estadounidense en 1934 para evitar el insider trading. Se encuentra construida como una

regarding a tender offer. Because Rule 10b5-1 does not expressly provide a defense in the event that the person who establishes a trading plan comes into possession of material nonpublic information regarding a tender offer, the plan should provide for cancellation when the person comes into possession of that kind of information. Of course, to be effective, the person needs to communicate that fact, on a confidential basis, to the entity that is implementing the plan. Alternatively, the person whose plan does not include that automatic termination clause should unilaterally terminate the plan upon learning of the information regarding the tender offer." (p. 10).

${ }^{109} 666$ Fed. Supp. 799 (1987).

${ }^{110}$ Id. p. 813 y 816.

11116 F. Supp. 123 (1995).

112 Este argumento no fue controvertido por la defensa en su apelación ante la Corte de Apelaciones del Segundo Circuito, por lo que la cuestión no fue tematizada en la sentencia de segunda instancia que confirmó la sentencia apelada: SEC v. Mayhew, 121 F3rd 44 (2d Cir. 1997).

113 STEINBERG, Securities Regulation, cit. nota $n^{\circ} \quad 50, \quad \S \S \quad 4.01-4.07$, esp. $\$ \quad 4.06$; LOSS/SELIGMAN/PAREDES, Fundamentals, pp. 893-916; WANG/STEINBERG, Insider Trading, cit. nota $\mathrm{n}^{\circ} 50, \S 14.1-14.12$, especialmente $\S 14.10 .1$ y 14.10.2; LANGEVOORT, Insider Trading, cit. nota $\mathrm{n}^{\circ} 50, \S \S$ 10:1-10:6; HAZEN, Treatise, cit. nota $n^{\circ} 50, \S \S$ 13.2-13.6; HAZEN, Thomas Lee, "The New Pragmatism under Section 16b of the Securities Exchange Act", North Carolina Law Review n' 54 (1975) 1-57.

11415 U.S. Code $\S 78$ p (...) (b) Profits from purchase and sale of security within six months. For the purpose of preventing the unfair use of information which may have been obtained by such beneficial owner, director, or officer by reason of his relationship to the issuer, any profit realized by him from any purchase and sale, or any sale and purchase, of any equity security of such issuer (other than an exempted security) or a securitybased swap agreement involving any such equity security within any period of less than six months, unless such security or security-based swap agreement was acquired in good faith in connection with a debt previously contracted, shall inure to and be recoverable by the issuer, irrespective of any intention on the part of such beneficial owner, director, or officer in entering into such transaction of holding the security or security-based swap agreement purchased or of not repurchasing the security or security-based swap agreement sold for a period exceeding six months. Suit to recover such profit may be instituted at law or in equity in any court of competent jurisdiction by the issuer, or by the owner of any security of the issuer in the name and in behalf of the issuer if the issuer shall fail or refuse to bring such suit within sixty days after request or shall fail diligently to prosecute the same thereafter; but no such suit shall be brought more than two years after the date such profit was realized. This subsection shall not be construed to cover any transaction where such beneficial owner was not such both at the time of the purchase and sale, or the sale and purchase, of the security or security-based swap agreement or a security-based swap involved, or any 
Polít. crim. Vol. 12, № 23 (Julio 2017), Art. 13, pp. 453-532.

[http://www.politicacriminal.cl/Vol_12/n_23/Vol12N23A13.pdf]

regla preventiva ("profiláctica") que prohíbe la compra o la venta por un insider de valores del emisor en el que se desempeña dentro de los seis meses que siguen a su venta o compra precedente, respectivamente. En relación con el insider trading es una regla "objetiva" y "absoluta", en el sentido que su infracción no presupone uso ni posesión de información privilegiada por el insider que realiza las operaciones prohibidas ${ }^{115}$.

No obstante estas características de la disposición legal, la jurisprudencia federal estadounidense ha desarrollado lo que se denomina una "concepción pragmática" de la regla, consistente en reconocer circunstancias excepcionales que corresponden a operaciones sucesivas "no ortodoxas" que pese a satisfacer todas las condiciones de la regla se entienden sin embargo excluidas de su supuesto de hecho. La sentencia de la USSC que aún gobierna esta cuestión es Kern County Land Co. V. Occidental Petroleum Corp ${ }^{116}$. El caso consistió en que una vez que la sociedad objetivo de una tender offer (Kern) logró resistirla mediante una fusión con otra sociedad (Tenneco), el oferente frustrado (Occidental), teniendo más del 10\% de las acciones, pactó con esa otra sociedad una oferta de compra de las acciones correspondientes por conversión a las que poseía de la sociedad objetivo de la tender offer. El ejercicio de la opción reportó alrededor de US\$ 19.000.000 a Occidental y Kern demandó la restitución de las utilidades bajo la $§ 16$ b SEA. Para resolver la cuestión de si la opción celebrada entre Occidental y Tenneco constituía una venta la Corte validó la interpretación restrictiva de la bajo consideraciones teleológicas en los siguientes términos:

"Although traditional cash-for-stock transactions that result in a purchase and sale or a sale and purchase within the six-month, statutory period are clearly within the purview of 16 (b), the courts have wrestled with the question of inclusion or exclusion of certain "unorthodox" transactions. The statutory definitions of 'purchase' and 'sale' are broad and, at least arguably, reach many transactions not ordinarily deemed a sale or purchase. In deciding whether borderline transactions are within the reach of the statute, the courts have come to inquire whether the transaction may serve as a vehicle for the evil which Congress sought to prevent -the realization of short-swing profits based upon access to inside information- thereby endeavoring to implement congressional objectives without extending the reach of the statute beyond its intended limits. The statute requires the inside, short-swing trader to disgorge all profits realized on all 'purchases' and 'sales' within the specified time period, without proof of actual abuse of insider information, and without proof of intent to profit on the basis of such information. Under these strict terms, the prevailing view is to apply the statute only when its application would serve its goals. '[W] here alternative constructions of the terms of 16 (b) are possible, those terms are to be given the construction that best serves the congressional purpose of curbing short-swing speculation by corporate insiders.' Reliance Electric Co. v. Emerson Electric Co., 404 U.S., at 424 . See Blau v. Lamb, 363 F.2d 507 (CA2 1966), cert. denied, 385 U.S. 1002(1967). Thus, "[i]n interpreting the terms 'purchase' and 'sale', courts have properly asked whether the

transaction or transactions which the Commission by rules and regulations may exempt as not comprehended within the purpose of this subsection." La $\S 16$ b SEA debe ser considerada como una fuente material de la prohibición originaria del insider trading en el art. 13 de la Ley 18045.

${ }^{115}$ El precedente que gobierna esta comprensión de la regla es Smolowe et al $v$. Delendo Corporation et al 136 F. 2d 231 (1943).

116411 U.S. 582 (1973). 
BASCUÑÁN, Antonio. "Posesión, uso y explotación de la información privilegiada como elementos del insider trading en el derecho comparado del mercado de valores".

particular type of transaction involved is one that gives rise to speculative abuse." Reliance Electric Co. v. Emerson Electric Co., supra, at 424 n. 4". ${ }^{117}$

Aplicando esta metodología de interpretación, la Corte concluyó en el caso que si bien la tender offer había constituido a Occidental un beneficiario con más del 10\% de las acciones de Kern no le había dado acceso a información privilegiada, tampoco en relación con Tenneco; que después de la fusión de Kern con Tenneco la conversión de acciones de la primera en acciones de la segunda había sido involuntaria para Occidental, y que la opción pactada por Occidental con Tenneco respondía al beneficio mutuo de un accionista minoritario que deseaba terminar con una inversión que no había escogido y a la administración de una sociedad que prefería no tener un accionista minoritario potencialmente conflictivo, y que la opción no había sido una fuente de abuso especulativo potencial, pues Occidental no tenía información acerca de Tenneco o sus nuevas acciones. Por esas razones la Corte negó que la opción de venta a Tenneco posterior a la compra en el contexto de la tender offer constituyera short-swing profit de Occidental prohibido por la $\S$ $16 \mathrm{~b}$ SEA.

La concepción pragmática de la prohibición de short-swing profit demuestra la necesidad de reconocer el carácter sobreinclusivo de las reglas que no describen en el supuesto de hecho de la norma sancionatoria (o en el frástico de la prohibición) el insider trading que se pretende sancionar o prohibir con expresión de todos los elementos que lo componen conforme al fundamento de su prohibición o sanción. La SEC ha buscado resolver el problema de la sobreinclusividad de la $\S 16 \mathrm{~b}$ SEA mediante el establecimiento de exenciones específicas ${ }^{118}$. Pero la jurisprudencia mantiene la tesis de Kern para resolver casos "no-ortodoxos" de operaciones sucesivas realizadas dentro del período de seis meses. Una restricción teleológica de la sobreinclusividad de la regla ha demostrado ser aquí "la solución más satisfactoria si es aplicada con moderación"

\section{La distinción entre uso y posesión de la información privilegiada en el derecho europeo.}

Dejando de lado los documentos que corresponden a la protohistoria del derecho común europeo sobre insider trading -el Informe Segré de 1966 y el Código de Conducta de 1977- en los últimos 25 años éste ha contado con tres cuerpos regulativos: (i) la Directiva 89/592/CEE, del Consejo, de 13 de noviembre de 1989, referida exclusivamente al insider trading, (ii) la Directiva 2003/6/CE del Parlamento Europeo y del Consejo, de 28 de enero de 2003, referida tanto al insider trading como a la manipulación de precios, ambos tematizados como "abuso de mercado", y (iii) el Reglamento (UE) 596/2014 del Parlamento Europeo y el Consejo, de 16 de abril de 2014, sobre abuso de mercado, complementado por la Directiva 2014/57/UE del Parlamento Europeo y del Consejo, de 16 de abril de 2014, sobre sanciones penales aplicables al abuso de mercado.

\footnotetext{
${ }^{117}$ Id. 593-595.

${ }^{118}$ Las excepciones se encuentran en las Reglas 16b-1 (exención administrativa), 16b-3 (opciones de compra ofrecidas por el emisor a sus insiders), 16b-5 (donaciones de buena fe y herencias), 16b-6 (derivados) y 16b-7 (fusiones) SEC.

${ }^{119}$ HAZEN, "The New Pragmatism", cit. nota n ${ }^{\circ} 113$, p. 57.
} 
Polít. crim. Vol. 12, № 23 (Julio 2017), Art. 13, pp. 453-532.

[http://www.politicacriminal.cl/Vol_12/n_23/Vol12N23A13.pdf]

Los principales aspectos tematizados por las distintas regulaciones europeas del insider trading se refieren a elementos que no interesan específicamente a este artículo: concepto de información privilegiada, círculo de destinatarios de las prohibiciones asociadas a la posesión de información privilegiada, bienes a los cuales se refieren la información y las prohibiciones y mercados alcanzados por ellas. No obstante, cada una de las tres regulaciones adopta una formulación de la PO que sí es relevante para este artículo. Asimismo, cada una de ellas reconoce excepciones explícitas o implícitas que también son directamente relevantes. Finalmente, en el tránsito de una a otra también se encuentran antecedentes importantes. A diferencia del derecho federal estadounidense, ninguna de estas consideraciones se relaciona con una comprensión de la prohibición del insider trading que lo reduzca a un conflicto fiduciario entre partes individuales o pretenda diluir su relevancia como atentado a la (confianza en la) integridad del mercado de valores. Por el contrario, desde su surgimiento en 1989 la prohibición europea del insider trading ha respondido al "macro-enfoque" de la eficiencia del mercado de valores para distribuir recursos mediante el mecanismo de formación de precios, asumiendo que la confianza del inversionista en el proceso de formación de precios - esto es, con flujo inmediato, directo y debida consideración a la igualdad de oportunidades- incide en esa eficiencia ${ }^{120}$. Es en este contexto que se afirma la licitud de las operaciones efectuadas en ejecución de una orden previa a la posesión de la información privilegiada, ya sea como consecuencia de la formulación de la prohibición o de una exención o defensa implícita o explícita a su alcance.

En las secciones siguientes se analizará la formulación de la prohibición de insider trading en las distintas regulaciones europeas (3.1, 3.2 y 3.4), incluyendo la mención de su recepción en distintos Estados miembros de la Comunidad/Unión Europea. Entre la regulación de 2003 y la de 2014 es indispensable analizar un caso judicial ante el ECJ (3.3), Posteriormente se examinará el estatus de la orden previa bajo cada una de esas regulaciones (3.5.1). Ese examen será complementado con una breve referencia al estatus de la orden previa en el derecho alemán e inglés (3.5.2) y una referencia algo más extensa al estatus de la orden previa en el derecho francés (3.5.3).

\subsection{La Directiva 89/592/CEE, del Consejo, de 13 de noviembre de $1989^{121}$.}

La DIT establece en su art. 2 un imperativo a los Estados miembros de la -entoncesComunidad Económica Europea de prohibir ciertos comportamientos relacionados con la posesión de información privilegiada. En su versión en castellano la parte de la disposición que relevante para este artículo es la siguiente:

\footnotetext{
${ }^{120}$ MOLONEY, Niamh, EU Securities and Finantial Markets Regulation, Oxford: Oxford University Press, 2014, pp. 700-703, especialmente nota 27.

${ }^{121}$ Al respecto: MCGUINNESS, Christine A., "Note: Toward the Unification of European Capital Markets: The EEC's Proposed Directive on Insider Trading” 11 Fordham International Law Journal (1987), p. 432452; HOPT, Klaus J., "The European Insider Dealing Directive”, Common Market Law Review n 27 (1990), pp. 51-82; MOLONEY, EU Securities, cit. nota ${ }^{\circ}$ 120, pp. 707-708. Las distintas versiones idiomáticas de la Directiva se encuentran disponibles en: http://eur-lex.europa.eu/legal-content/ES/TXT/?uri=CELEX:31989L0592 (última consulta: 06.03.2015).
} 
BASCUÑÁN, Antonio. "Posesión, uso y explotación de la información privilegiada como elementos del insider trading en el derecho comparado del mercado de valores".

“Artículo 2. 1. Cada Estado miembro prohibirá a las personas que: (...) dispongan de una información privilegiada, adquirir o ceder por cuenta propia o ajena, ya sea directa o indirectamente, los valores del emisor o de los emisores afectados por dicha información privilegiada explotándola con conocimiento de causa."

La descripción del presupuesto de la acción como "disponer" de una información privilegiada" no es más que una forma de referirse a su posesión ${ }^{122}$. La función del elemento de la infracción consistente en "explota[r] [la información privilegiada] con conocimiento de causa" es ambivalente. Para ilustrar su ambivalencia conviene comparar la versión en castellano con las versiones en inglés y francés

"Article 2. 1. Each Member State shall prohibit any person who (...) possesses inside information from taking advantage of that information with full knowledge of the facts by acquiring or disposing of for his own account or for the account of a third party, either directly or indirectly, transferable securities of the issuer or issuers to which that information relates".
"Article 2. 1 . Chaque État membre interdit aux personnes qui : (...) disposent d'une information privilégiée, d'acquérir ou de céder pour compte propre ou pour compte d'autrui, soit directement soit indirect-tement, les valeurs mobilières de l'émetteur ou des émetteurs concernés par cette information, en exploitant en connaissance de cause cette information privilégiée."

Claramente, la sintaxis de la versión francesa coincide con la sintaxis de la versión española, e indica que la explotación de la información es un modo específico de comisión de la acción de operar en posesión de información privilegiada. Por eso, no toda operación en posesión de información constituye infracción; o, lo que es lo mismo, que la norma que la DIT ordena establecer no es una POP sino una POU. En cambio, la sintaxis de la versión inglesa admite una comprensión de la explotación de información privilegiada, descrita en términos de "tomar ventaja" ("taking advantage") de ella, como una denominación de la acción de operar en posesión de la información: la información se aprovecha, por definición, cuando se realiza la operación. Conforme a esta comprensión, toda operación en posesión de información privilegiada implica un aprovechamiento de la misma y por lo tanto es constitutiva de infracción; o, lo que es lo mismo, que la norma que la DIT ordena establecer es una POP.

La comprensión generalizada de la prohibición impuesta por la DIT fue la que corresponde a las versiones española y francesa. La sintaxis de esas versiones era compartida también por las versiones alemana ${ }^{123}$ italiana $^{124}$ y portuguesa $^{125}$.

\footnotetext{
${ }^{122}$ Las versiones alemana, francesa, italiana y portuguesa usan el término equivalente a "dispongan" en sus respectivos idiomas. La versión inglesa, donde el verbo "to dispose" no tiene el sentido de tener a disposición algo sino de transferirlo o deshacerse de él, usa como equivalente "possess".

123 "Artikel 2. (1 ) Jeder Mitgliedstaat untersagt den Personen, die (...) über eine Insider Information verfügen, unter Ausnutzung derselben in Kenntnis der Sache für eigene oder fremde Rechnung entweder selbst oder indirekt die Wertpapiere des bzw. der von dieser Information betroffenen Emittenten zu erwerben oder zu veräußern."

124 "Articolo 2. 1. Ciascuno Stato membro vieta alle persone che dispongono di un'informazione privilegiata, (...) di acquisire o di cedere, per conto proprio o per conto terzi, direttamente o indirettamente i valori mobiliari dell'emittente o degli emittenti interessati da questa informazione, sfruttando consapevolmente tale informazione privilegiata."
} 
Polít. crim. Vol. 12, No 23 (Julio 2017), Art. 13, pp. 453-532.

[http://www.politicacriminal.cl/Vol_12/n_23/Vol12N23A13.pdf]

La legislación de los distintos Estados miembros de la entonces Comunidad Económica Europea no siguió un mismo patrón en la transposición de la DIT.

Así, por ejemplo, Suiza y Alemania establecieron una prohibición de operación en aprovechamiento de la información privilegiada, es decir, mediante una POU formulada conforme a un estándar estricto de uso o de explotación. Suiza lo hizo introduciendo en 1988 una disposición en el Código Penal, basándose en los trabajos preparatorios de la DIT $^{126}$. Alemania lo hizo introduciendo en 1994 una norma de comportamiento y normas sancionatorias en la $\mathrm{WpHG}^{127}$.

Por contraste, España e Italia establecieron una POP. En España esa formulación se encontraba establecida en la Ley de LMV-E con anterioridad a la recepción de la DIT y fue ratificada con ocasión de su transposición en $1991^{128}$. En Italia la transposición de la DIT con esa fórmula constituyó la primera regulación legal del insider trading, contenida en el art. 2-1 de la Ley 157/1991, de 17 de mayo, Norme relative all'uso di informazioni riservate nelle operazioni in valori mobiliari e alla Commissione Nazionale per le Societá e la Borsa (en adelante "L 157/91") ${ }^{129}$. En 1998, sin embargo, Italia sustituyó esta regulación

125 “Artigo 2. 1. Cada Estado-membro proibirá às pessoas que (...) disponham de uma informação privilegiada que adquiram ou cedam, em seu nome ou em nome de outrém, quer directa quer indirectamente, valores mobiliários do emitente ou emitentes a quem a informação diz respeito, explorando com conhecimento de causa essa informação privilegiada."

${ }^{126}$ El Art. 161. 1. del StGB-S, introducido el 01.07.1988, era del siguiente tenor: "Wer als Mitglied des Verwaltungsrates, der Geschäftsleitung, der Revisionsstelle oder als Beauftragter einer Aktiengesellschaft oder einer sie beherrschenden oder von ihr abhängigen Gesellschaft, als Mitglied einer Behörde oder als Beamter, oder als Hilfsperson einer der vorgenannten Personen, sich oder einem andern einen Vermögensvorteil verschafft, indem er die Kenntnis einer vertraulichen Tatsache, deren Bekanntwerden den Kurs von in der Schweiz börslich oder vorbörslich gehandelten Aktien, andern Wertschriften oder entsprechenden Bucheffekten der Gesellschaft oder von Optionen auf solche in voraussehbarer Weise erheblich beeinflussen wird, ausnützt oder diese Tatsache einem Dritten zur Kenntnis bringt, wird mit Gefängnis oder Geldstrafe bestraft.". Traducción personal: "El que como miembro de un consejo de administración, de la dirección comercial, de una institución de revisión o como mandatario de una sociedad de acciones o de una sociedad que la controla o que es controlada por ella, como miembro de una institución, como funcionario público o como auxiliar de una de las personas antes mencionadas, obtiene para sí mismo o para otro una ventaja patrimonial en tanto él aprovecha el conocimiento de un hecho confidencial, cuya divulgación influirá previsible y considerablemente en el curso de acciones transadas en Suiza dentro o antes de la bolsa, o los valores contables respectivos de la sociedad u opciones a las mismas, o da conocimiento de ese hecho a un tercero". En el año 2002 la pena fue aumentada a privación de libertad de hasta tres años. Este artículo fue derogado el año 2012 (infra, nota $\mathrm{n}^{\circ} 146$ ).

${ }^{127}$ La norma de comportamiento se encuentra en el $\S 14 \mathrm{WpHG}$, introducido por la $2^{\mathrm{a}}$ Ley de Fomento del Mercado Financiero (2. Finanzmarktförderungsgesetz, de 01.08.1994) con el siguiente tenor: "\$ 14 Verbot von Insidergeschäften. (1) Einem Insider ist es verboten, / 1. unter Ausnutzung seiner Kenntnis Insiderpapiere für eigene oder fremde Rechnung oder für einen anderen zu erwerben oder zu veräußern, (...)". Traducción personal: "Prohibición de negocios de insider. (1) Está prohibido a un insider, / 1. Adquirir o enajenar a cuenta propia o ajena, o para otro, valores de insider [i.e. a los que se refiere la información privilegiada] mediante aprovechamiento de información de su conocimiento (...)". Disponible en: http://www.kapitalmarktrecht-im-

internet.eu/de/Rechtsgebiete/Gesellschaftsrecht/Artikelgesetze/7/2._FFG.htm (última consulta: 25.11.2016).

${ }^{128}$ Infra, sección 4.1 .

129 “Art. 2. 1. É vietato acquistare o vendere, ovvero compiere altre operazioni, anche per interposta persona, su valori mobiliari, ivi compresi i relativi diritti di opzione, qualora si posseggano informazioni riservate ottenute in virtù della partecipazione al capitale di una società ovvero in ragione dell'esercizio di una 
BASCUÑÁN, Antonio. "Posesión, uso y explotación de la información privilegiada como elementos del insider trading en el derecho comparado del mercado de valores".

mediante el establecimiento del TUF mediante Decreto Legislativo de 24 de febrero de 1998, cuyos artículos 184 y 187 bis describen el comportamiento ilícito como una operación en utilización de la información privilegiada, o sea, como una $\mathrm{POU}^{130}$.

En un punto intermedio entre los dos modelos opuestos se encuentra la transposición efectuada por el Reino Unido mediante la tipificación del delito de insider dealing por la $\S$ 52-(1) y -(3) de la CJA-1993 ${ }^{131}$. Esta regulación hace punible la operación en posesión de información privilegiada, pero la $\S 52$-(4) CJA-1993 subordina la punibilidad del insider dealing a la $\S 53$, que en su número (1) reconoce un régimen de defensas tan amplio que en sus resultados hace del supuesto de hecho de la norma punitiva una operación en uso de información con inversión de la carga de la prueba ${ }^{132}$.

La explotación de la información privilegiada como elemento de la infracción fue entendida no sólo como exigencia de una conexión entre el conocimiento de la información y la razón o motivo de la operación, sino principalmente como una intención referida a la obtención de un resultado ulterior a la operación, cual es la obtención de un beneficio económico o la evitación de una pérdida ${ }^{133}$. Bajo esta comprensión, la explotación de la información cumplía el rol de un elemento subjetivo del tipo, específicamente, de una tendencia interna

funzione, anche pubblica, professione o ufficio." Disponible en: http://www.normattiva.it/urires/N2Ls?urn:nir:stato:legge:1991;157 (última consulta: 06.03.2015). Con razón la doctrina observó que el "carácter absoluto" de esta prohibición, consistente en un "puro y simple deber de abstención", guardaba semejanza con los deberes de abstención derivados de relaciones fiduciarias individuales (FOFFANI, Luigi, "Tutela penal del Mercado y abuso de información privilegiada: La experiencia italiana", en: ARROYO ZAPATERO, Luis, et al, Hacia un Derecho Penal Económico. Jornadas en Honor del Profesor Klaus Tiedemann. Madrid: Boletín Oficial del Estado, 1995, pp. 501-517, pp. 510-511).

130 "Art. 184. (Abuso di informazioni privilegiate) / 1. È punito con la reclusione da uno a sei anni e con la multa da euro ventimila a euro tre milioni chiunque, essendo in possesso di informazioni privilegiate in ragione della sua qualità di membro di organi di amministrazione, direzione o controllo dell'emittente, della partecipazione al capitale dell'emittente, ovvero dell'esercizio di un'attività lavorativa, di una professione o di una funzione, anche pubblica, o di un ufficio: / a) acquista, vende o compie altre operazioni, direttamente o indirettamente, per conto proprio o per conto di terzi, su strumenti finanziari utilizzando le informazioni medesime; (...)". "Art. 187-bis (Abuso di informazioni privilegiate) / 1. Salve le sanzioni penali quando il fatto costituisce reato, è punito con la sanzione amministrativa pecuniaria da euro ventimila a euro tre milioni chiunque, essendo in possesso di informazioni privilegiate in ragione della sua qualità di membro di organi di amministrazione, direzione o controllo dell'emittente, della partecipazione al capitale dell'emittente, overo dell'esercizio di un'attività lavorativa, di una professione o di una funzione, anche pubblica, o di un ufficio: a) acquista, vende o compie altre operazioni, direttamente o indirettamente, per conto proprio o per conto di terzi su strumenti finanziari utilizzando le informazioni medesime; (...)". Disponible en: http://www.normattiva.it/uri-res/N2Ls?urn:nir:stato:decreto.legislativo:1998;058 (última consulta: 06.03.2015).

131 " $\$ 52$. The Offence. (1) An individual who has information as an insider is guilty of insider dealing if, in the circumstances mentioned in subsection (3), he deals in securities that are price-affected securities in relation to the information. (...) (3) The circumstances referred to above are that the acquisition or disposal in question occurs on a regulated market, or that the person dealing relies on a professional intermediary or is himself acting as a professional intermediary."

${ }_{132}^{132}$ Infra, sección 3.5.3.

${ }^{133}$ Desde el punto de vista de la causalidad psíquica, tal como se señaló antes (supra, sección 1), la doctrina alemana entendió el elemento de la explotación de la información como una exigencia de prueba de causalidad necesaria. 
Polít. crim. Vol. 12, No 23 (Julio 2017), Art. 13, pp. 453-532.

[http://www.politicacriminal.cl/Vol_12/n_23/Vol12N23A13.pdf]

trascendente. Esta fue la principal razón que originó su desaparición en la evolución del derecho común europeo.

\subsection{La Directiva 2003/6/CE del Parlamento Europeo y del Consejo, de 28 de enero de $2003^{134}$.}

La DAM, que reemplazó a la DIT, establece en el párrafo 1 de su artículo 2 el imperativo de prohibir el insider trading. Su versión española es del siguiente tenor:

"Artículo 2. 1. Los Estados miembros prohibirán a cualquier persona de las citadas en el párrafo segundo que posea información privilegiada utilizar dicha información adquiriendo o cediendo o intentando adquirir o ceder, por cuenta propia o de terceros, directa o indirectamente, instrumentos financieros a que se refiera dicha información”.

Como salta a la vista, la redacción de la disposición sustituye la mención a la explotación de la información privilegiada como elemento de la infracción por una mención a su utilización. Ese es un cambio deliberado, cuya finalidad consistió en eliminar cualquier exigencia que pudiera ser interpretada en el sentido de un elemento subjetivo adicional al conocimiento de los hechos que se requiera conforme a las reglas generales de imputación de responsabilidad, ya sea administrativa o penal $^{135}$.

El cambio proviene de la enmienda 27 al proyecto de la Comisión Europea, propuesta en 2002 por el Comité sobre Asuntos Económicos y Monetarios del Parlamento Europeo ("Informe Goebbels") ${ }^{136}$. La comparación entre el proyecto de la comisión y la enmienda es suficientemente expresiva:

134 Las distintas versiones idiomáticas de la Directiva se encuentran disponibles en: http://eurlex.europa.eu/legal-content/ES/ALL/?uri=CELEX:32003L0006 (última consulta: 25.11.2016).

135 OPITZ, Peter, "Anmerkung zum EUGH: Nutzung von Insiderinformationen nach der Marktmissbrauchtsrichtlinie - Spector Photo NV”, BKR - Zeitschrift für Bank- und Kapitalmarktrecht 2010, pp. 71-74; SEREDYNSKA, Iwona, Insider Dealing and Criminal Law. Berlin: Springer, 2012, pp. 24-25.

${ }^{136}$ Informe sobre la propuesta de directiva del Parlamento Europeo y del Consejo sobre las operaciones con información privilegiada y la manipulación del mercado (abuso del mercado) (COM(2001) 281 - C50262/2001 - 2001/0118(COD)) - Comisión de Asuntos Económicos y Monetarios. A5-0069/2002. RR\462759ES.doc. PE 307.438, Disponible en:

http://www.europarl.europa.eu/sides/getDoc.do?pubRef=-//EP//NONSGML+REPORT+A5-2002-

0069+0+DOC+PDF+V0//ES) (última visita: 25.11.2016). 
BASCUÑÁN, Antonio. "Posesión, uso y explotación de la información privilegiada como elementos del insider trading en el derecho comparado del mercado de valores".

PROYECTO COMISIÓN

“1. Los Estados miembros prohibirán a cualquier persona física o jurídica que posea información privilegiada aprovecharse de dicha información por medio de adquirir o ceder por cuenta propia o de terceros, ya sea directa o indirectamente, instrumentos financieros a que se refiera dicha información."
ENMIENDA 27

La sustitución de la expresión "aprovecharse" ("taking advantage”) por la expresión "y use" ("from using") es justificada por el Informe Goebbels como prescindencia de un elemento subjetivo: "El mero uso de información privilegiada debería ser sancionado en el contexto administrativo, en consecuencia debería suprimirse todo elemento referido a la finalidad o la intención." "138 La cuestión de si se trata de un elemento subjetivo referido a un resultado ulterior a la acción (la obtención del beneficio/evitación del perjuicio) o del elemento subjetivo correlativo a la conexión de sentido entre el conocimiento de la información y la decisión de realizar la operación $-\mathrm{o}$ sea, de una prescindencia de causalidad- queda abierta. El Informe Goebbels califica la regla como "enfoque objetivo" y de ello deduce la necesidad de una excepción para la orden previa ${ }^{139}$. En todo caso, la justificación de la enmienda no se opone a un diseño más restrictivo de la norma punitiva del insider trading.

Esta ambivalencia de la sintaxis de la disposición plantea ahora en relación con el elemento "utilizar" la información privilegiada como parte de la descripción de la infracción la misma ambivalencia que planteaba el elemento "taking advantage" en la sintaxis de la versión inglesa de la DIT. Pues se puede entender esa expresión en el sentido de que la operación constituye infracción sólo cuando tiene lugar utilizándose la información privilegiada -o sea, que ordena establecer una POU-, como también se la puede entender en el sentido de que toda operación en posesión de información privilegiada constituye por definición utilización de la misma - $\mathrm{o}$ sea, que ordena establecer una POP-. La versión alemana de la DAM resolvió la ambivalencia inequívocamente, en el sentido de hacer de la utilización un modo específico de comisión de la infracción ${ }^{140}$. Pero las versiones de la

\footnotetext{
${ }^{137}$ Op. cit. nota ${ }^{\circ} 136$, pp. $24-25 / 83$.

138 Ibídem.

${ }^{139}$ La regla es introducida por la enmienda 29, como nuevo art. 2-3 bis, en los siguientes términos: "No se aplicará el presente artículo a las operaciones efectuadas para garantizar la ejecución de obligaciones vencidas de adquisición o de cesión de instrumentos financieros, cuando resulten de acuerdos celebrados antes de encontrarse en posesión de una información privilegiada." (op. cit. nota $n^{\circ} 136$ p. 26/83). Su justificación se encontraría, según el Informe Goebbels en la siguiente razón: "Puesto que la Directiva preconiza un enfoque objetivo para la definición de las operaciones con información privilegiada y de manipulación del mercado, es necesario prever la posibilidad de que los participantes en el mercado puedan defenderse en los casos en que actúen sobre la base de contratos celebrados antes de obtener una información privilegiada." (Ibídem).

140 “Artikel 2. (1) Die Mitgliedstaaten untersagen Personen im Sinne von Unterabsatz 2, die über eine InsiderInformation verfügen, unter Nutzung derselben für eigene oder fremde Rechnung direkt oder indirekt Finanzinstrumente, auf die sich die Information bezieht, zu erwerben oder zu veräußern oder dies zu versuchen."
} 
Polít. crim. Vol. 12, No 23 (Julio 2017), Art. 13, pp. 453-532.

[http://www.politicacriminal.cl/Vol_12/n_23/Vol12N23A13.pdf]

DAM en los demás idiomas aquí analizados mantuvieron la misma ambivalencia que la versión española $^{141}$.

Conforme a la documentación de la Comisión Europea, la ambivalencia en las formulaciones generó disparidad en las regulaciones de los Estados Miembros que traspusieron la DAM a sus respectivos derechos internos:

"(...) Member States have not taken a single view on how the concept of 'using inside information' should be transposed in the implementation of the insider dealing prohibition at national level. Two broad approaches could be distinguished at this stage:

- Whenever a person being in possession of inside information trades (or attempts to trade) it is in breach of the inside dealing prohibition.

- Use of inside information takes place only when a person trades (or attempts to trade) on the basis of inside information". ${ }^{142}$

España es el ejemplo más claro de un Estado miembro que transpuso la DAM mediante la formulación de una POP. En 2002, anticipando la regulación de la DAM, la legislación española ratificó la fórmula tradicional de la LMV-E ${ }^{143}$, aunque introduciendo la defensa del art. 2-3 DAM. La presencia de esta defensa implica respecto de ciertos casos la adopción del estándar modificado de posesión (infra, sección 3.5.a).

Como ejemplos de países que transpusieron la DAM mediante la formulación de una POU de información privilegiada cabe mencionar al Reino Unido y Alemania. El Reino Unido efectúo una recepción anticipada de la DAM, basada en sus trabajos preparatorios,

\footnotetext{
${ }^{141}$ Así, las versiones: (i) inglesa: "Article 2. 1. Member States shall prohibit any person referred to in the second subparagraph who possesses inside information from using that information by acquiring or disposing of, or by trying to acquire or dispose of, for his own account or for the account of a third party, either directly or indirectly, financial instruments to which that information relates."; (ii) francesa: Article 2. 1. Les États membres interdisent à toute personne visée au deuxième alinéa qui détient une information privilégiée d'utiliser cette information en acquérant ou en cédant, ou en tentant d'acquérir ou de céder, pour son compte propre ou pour le compte d'autrui, soit directement, soit indirectement, les instruments financiers auxquels se rapporte cette information."; (iii) italiana: Articolo 2. 1. Gli Stati membri vietano alle persone di cui al secondo comma che dispongono di informazioni privilegiate di utilizzare tali informazioni acquisendo o cedendo, o cercando di acquisire o cedere, per conto proprio o per conto terzi, direttamente o indirettamente, gli strumenti finanziari cui le informazioni si riferiscono."; (iv) portuguesa: "Artigo 2. 1. Os EstadosMembros proíbem qualquer pessoa referida no segundo parágrafo que detenha informação privilegiada de utilizar essa informação ao adquirir ou alienar, tentar adquirir ou alienar, por sua conta ou por conta de terceiro, directa ou indirectamente, os instrumentos financeiros a que essa informação diga respeito."

${ }^{142}$ Comisión Europea, Call for evidence. Review of Directive 2003/6/EC on insider dealing and market manipulation (Market Abuse Directive), sección 2.2.3, p. 12-13. Disponible en:

http://ec.europa.eu/internal_market/consultations/docs/2009/market_abuse/call_for_evidence.pdf (última consulta: 25.11.2016). Al respecto, WELCH, Jane, PANNIER, Matthias, BARRACHINO, Eduardo, BERND, Jan, LEDEBOER, Philip, Comparative Implementation of EU Directives (I) - Insider Dealing and Market Abuse. Londres: The British Institute of International and Comparative Law. City Research Series Nr. 8 (2005). Disponible en: http://www.cityoflondon.gov.uk/business/economic-research-andinformation/research-publications/Documents/2007-

2000/Comparative\%20Implementation\%20of\%20EU\%20Directives\%20I_Insider\%20Dealing\%20and\%20M arket\%20Abuse.pdf;

${ }^{143}$ Infra, sección 4.1 .
} 
BASCUÑÁN, Antonio. "Posesión, uso y explotación de la información privilegiada como elementos del insider trading en el derecho comparado del mercado de valores".

mediante el establecimiento de la FSMA de 2000, que en su art. 118(2)(a) formula la prohibición del insider dealing como forma de abuso de mercado describiéndolo como operación "basada en" información privilegiada, es decir, adoptando la formulación estadounidense del estándar de uso (R 10b5-1(a) SEC) ${ }^{144}$. Alemania cambió en 2004 la antigua formulación de 1994 basada en la DIT, que suponía una operación en explotación de la información por una formulación que exige que la operación sea realizada "utilizando" (literalmente, "bajo utilización de") información privilegiada ${ }^{145}$.

Por su parte, Suiza efectuó una transposición de la DAM haciendo caso omiso de su sustitución del estándar de explotación por el estándar de uso de la información. A partir de 2012 la prohibición del insider trading en Suiza se encuentra en el art. 40-1-a de la BGEH. La ley federal suiza sobre modificación de la BGEH, de 28.09.2012, que introdujo el nuevo art. 40 BGEH y derogó los arts. 161 y 161 bis CP-S con la finalidad de adecuar la regulación suiza a la DAM, mantuvo la descripción del comportamiento ilícito como "aprovechar la información"146.

144 "Market Abuse. 118. (1) For the purposes of this Act, market abuse is behaviour (whether by one person alone or by two or more persons jointly or in concert) - / (a) which occurs in relation to qualifying investments traded on a market to which this section applies; / (b) which satisfies any one or more of the conditions set out in subsection (2); and / (c) which is likely to be regarded by a regular user of that market who is aware of the behaviour as a failure on the part of the person or persons concerned to observe the standard of behaviour reasonably expected of a person in his or their position in relation to the market. / (2) The conditions are that - (a) the behaviour is based on information which is not generally available to those using the market but which, if available to a regular user of the market, would or would be likely to be regarded by him as relevant when deciding the terms on which transactions in investments of the kind in question should be effected;" CLARKE asocia el art. 118(2)(a) FSMA exclusivamente con el art. 2-1 DAM y lo entiende en consecuencia sometido a la ambigüedad de la traducción inglesa, haciendo de la operación en posesión una operación presuntivamente en uso conforme a la jurisprudencia del ECJ en el caso Spector (infra, sección 3.3) (CLARKE, Sarah, Insider Dealing. Law and Practice. Oxford: Oxford University Press, 2013, pp. 172-176).

${ }^{145}$ El § $14 \mathrm{WpHG}$ introducido por la Ley de Mejora de la Protección del Inversionista (Anlegerschutzverbesserungsgesetz), de 30.10.2004 es del siguiente tenor: "§ 14 Verbot von Insidergeschäften. (1) Es ist verboten, / 1. unter Verwendung einer Insiderinformation Insiderpapiere für eigene oder fremde Rechnung oder für einen anderen zu erwerben oder zu veräußern, (...)". Traducción personal: "Prohibición de negocios de insider. (1) Está prohibido, / 1. Adquirir o enajenar a cuenta propia o ajena, o para otro, valores de insider [i.e. a los que se refiere la información privilegiada] mediante utilización de información de insider [i.e., privilegiada] (...)". Por su parte, el § 38 WpHG dispone: "Strafvorschriften.(1) Mit Freiheitsstrafe bis zu fünf Jahren oder mit Geldstrafe wird bestraft, wer / 1. entgegen § 14 Abs. 1 Nr. 1 ein Insiderpapier erwirbt oder veräußert (...)". Traducción personal: "Disposiciones penales. (1) Será castigado con pena privativa de libertad de hasta cinco años o multa el que / 1. adquiere o enajena un valor de insider contravieniendo el § 14 párrafo 1 número 1". Disponible en: http://www.gesetze-im-internet.de/wphg/ (última consulta: 25.11.2016).

${ }^{146} \mathrm{El}$ art. 40-1 BGEH dispone: "Art. 40 Ausnützen von Insiderinformationen. 1. Mit Freiheitsstrafe bis zu drei Jahren oder Geldstrafe wird bestraft, wer als Organ oder Mitglied eines Leitungs- oder Aufsichtsorgans eines Emittenten oder einer den Emittenten beherrschenden oder von ihm beherrschten Gesellschaft oder als eine Person, die aufgrund ihrer Beteiligung oder aufgrund ihrer Tätigkeit bestimmungsgemäss Zugang zu Insiderinformationen hat, sich oder einem anderen einen Vermögensvorteil verschafft, indem er eine Insiderinformation: a. dazu ausnützt, Effekten, die an einer Börse oder einer börsenähnlichen Einrichtung in der Schweiz zum Handel zugelassen sind, zu erwerben, zu veräussern oder daraus abgeleitete Finanzinstrumente einzusetzen;”. Traducción personal: "Aprovechamiento de información privilegiada. 1. Será castigado con pena de privación de libertad de hasta 3 años o multa el que como órgano o miembro de un órgano de dirección o vigilancia de un emisor o de una sociedad controladora o controlada por el emisor, o como una persona que tiene acceso legítimo a información privilegiada por su participación o por su 
Polít. crim. Vol. 12, № 23 (Julio 2017), Art. 13, pp. 453-532.

[http://www.politicacriminal.cl/Vol_12/n_23/Vol12N23A13.pdf]

Finalmente, Francia transpuso la DAM mediante el art. 622-1 RGAMF $^{147}$ sin clarificar la estructura de la operación en uno u otro sentido, es decir, compartiendo íntegramente la ambivalencia del art. 2-1 DAM ${ }^{148}$.

La diferencia entre el modelo de la POP y el modelo de la POU es considerada por la Comisión Europea en el documento citado sólo desde el punto de vista de su extensión y operatividad comparativas, siendo ambas mayores en la primera formulación, obviamente. En la comprensión de la Comisión, la mayor amplitud del alcance de la formulación de la norma como POP sólo se ve reducida por las "posibilidades de exoneración explícitamente establecidas" en la DAM ${ }^{149}$.

Finalmente, en su informe la Comisión deja constancia que a la fecha se encontraba pendiente de decisión ante el ECJ el caso C 45-08, Spector Photo Groep versus CBFA, y estima prudente esperar su sentencia antes de involucrar a los servicios de la Comisión en la elaboración de medidas que puedan clarificar la ambivalencia.

\subsection{El caso Spector.}

Por resolución de 28 de noviembre de 2006 la Comisión belga del sector bancario, financiero y de seguros impuso una multa a la sociedad Spector Photo Group NV y a uno de sus directores, Chris van Raemdonck, por realizar operaciones de compra de acciones de la misma sociedad durante el año 2003 en posesión de información relativa a sus resultados, la cual una vez publicada elevó la cotización de las acciones de la sociedad ${ }^{150}$. Los afectados interpusieron un recurso ante el Tribunal de Apelaciones de Bruselas (Hof van beroep te Brussel) y éste planteó el 8 de febrero de 2008 ante el ECJ una petición de

actividad, obtiene para sí mismo o para otro una ventaja patrimonial en tanto: a. él aprovecha la información para adquirir o enajenar efectos en una bolsa o en una institución semejante a una bolsa autorizada para comerciar en Suiza o para hacer uso de instrumentos financieros derivados de ello".

${ }^{147}$ Infra, nota ${ }^{\circ} 216$.

${ }^{148}$ Infra, sección 3.5.3.

${ }^{149}$ Op. cit. supra nota 142, p. 13. Sobre estas posibilidades de exoneración, infra, sección 3.5.

${ }^{150}$ El artículo 25 de la Ley belga de supervisión financiera, en la versión de la Ley de 2 de agosto de 2002, aplicable a los hechos acaecidos entre el 1 de junio de 2003 y el 31 de diciembre de 2003, disponía: "Se prohíbe a toda persona que posea información privilegiada utilizar dicha información adquiriendo o cediendo o intentando adquirir o ceder, por cuenta propia o de terceros, directa o indirectamente, instrumentos financieros a que se refiera dicha información o instrumentos financieros afines [...]." El artículo 25, en su versión en vigor a partir del 1 de enero de 2004, introducida por la Ley de 22 de diciembre de 2003, es del siguiente tenor: "Se prohíbe a toda persona que posea información, de la que sabe o debió saber que reviste carácter privilegiado, adquirir o ceder o intentar adquirir o ceder, por cuenta propia o de terceros, directa o indirectamente, instrumentos financieros a que se refiera dicha información o instrumentos financieros afines [...]." (según sentencia citada infra, nota $n^{\circ} 167, \S \S 5,6$ ). Es decir, la modificación legal introducida con posterioridad a los hechos reemplazó una POU por una POP. La Comisión belga aplicó la ley vigente al momento de los hechos; los recurrentes sostuvieron que la ley posterior a los hechos era inaplicable por contravención de la DAM, lo que generaba un vacío legal que debía ser aplicado retroactivamente como ley más favorable (in mitius). 
BASCUÑÁN, Antonio. "Posesión, uso y explotación de la información privilegiada como elementos del insider trading en el derecho comparado del mercado de valores".

decisión prejudicial ${ }^{151}$. La petición planteó varias cuestiones al ECJ”, de las cuales la segunda y tercera eran del siguiente tenor:

“2) ¿Debe interpretarse el artículo 2, apartado 1, de la Directiva sobre abuso del mercado en el sentido de que el mero hecho de que una persona mencionada en el artículo 2, apartado 1, de la misma Directiva posea información privilegiada, adquiera o ceda, o intente adquirir o ceder, por cuenta propia o de terceros, instrumentos financieros a los que se refiere la información privilegiada, implica al mismo tiempo que hace uso de tal información privilegiada?

3) En caso de respuesta negativa a la segunda cuestión, ¿debe admitirse que para la aplicación del artículo 2 de la Directiva sobre abuso del mercado se requiera una decisión deliberada de utilizar la información privilegiada?"152

En relación con esta cuestión, la Abogado General, Juliane Kokott, observó en primer lugar que la DAM no se satisface con el mero conocimiento (posesión) de la información privilegiada, sino que exige su utilización, y que los términos "conocimiento" y "utilización" no son empleados usualmente como sinónimos. El conocimiento consiste en un determinado saber, y si bien la utilización supone un conocimiento previo ella no se produce sino hasta que desemboca en una actuación ${ }^{153}$. Posteriormente, observando la diferencia existente entre la versión en alemán del art. 2-1 DAM y las versiones en francés e inglés ${ }^{154}$, y sosteniendo la necesidad de una interpretación uniforme basada en consideraciones sistemáticas, teleológico-objetivas y teleológico-subjetivas ${ }^{155}$, la Abogado General pasa revista a diversos antecedentes relevantes para resolver la cuestión.

Por una parte, si bien el considerando $18^{\circ}$ DAM da a entender que la utilización de información puede consistir en la adquisición o enajenación de instrumentos financieros en conocimiento de la información privilegiada, hay casos reconocidos por ese mismo considerando y por el art. 2-3 DAM en que una operación en posesión de información privilegiada no constituye infracción a la prohibición del art. 2-1 ${ }^{156}$.

Por otra parte, los considerandos $12^{\circ}$ y $15^{\circ}$ DAM dejan entender que la finalidad de la directiva consiste en garantizar la integridad de los mercados financieros comunitarios, afianzar la confianza de los inversionistas en dichos mercados y garantizar la igualdad de

${ }^{151}$ Petición de decisión prejudicial planteada por el Hof van Beroep te Brussel (Bélgica) el 8 de febrero de 2008 - Spector Photo Group N.V. y Chris Van Raemdonck/ Commissie voor het Bank-, Financie- en Assurantiewezen (CBFA). Disponible en:

http://eur-lex.europa.eu/legal-content/es/TXT/PDF/?uri=uriserv\%3AOJ.C_.2008.107.01.0014.01.SPA (última consulta: 25.11.2016).

${ }^{152}$ El Tribunal de Apelaciones de Bruselas planteó estas dos cuestiones atendiendo a la tesis de los recurrentes (supra, nota 11). El TJE consideró que la petición era admisible no por esa consideración, sino en virtud de la correlación existente entre la legislación vigente a la fecha de los hechos y la DAM.

${ }^{153}$ Conclusiones de la Abogado General Sra. Juliane Kokott presentadas el 10 de septiembre de 2009. Asunto C-45/08 Spector Photo Group NV Chris Van Raemdonck contra Commissie voor het Bank-, Financie- en Assurantiewezen (CBFA), $\S \$ 45,46$. Disponible en:

http://eur-lex.europa.eu/legal-content/ES/TXT/HTML/?uri=CELEX:62008CC0045\&from=EN （última consulta: 25.11.2016).

${ }^{154}$ Op. cit. nota ${ }^{\circ} 153, \S \S 48,49$.

${ }^{155}$ Op. cit. nota $\mathrm{n}^{\circ} 153, \S 50$.

${ }^{156}$ Op. cit. nota $\mathrm{n}^{\circ} 153, \S \S 51,52$. Acerca del c. $18^{\circ}$ y el art. 2-3 DAM, infra, sección 3.5. 
Polít. crim. Vol. 12, № 23 (Julio 2017), Art. 13, pp. 453-532.

[http://www.politicacriminal.cl/Vol_12/n_23/Vol12N23A13.pdf]

oportunidades. Para lograr esa finalidad, la prohibición de las operaciones con información privilegiada debe ser configurada de una manera que asegure su operatividad. La formulación de la DIT, con su exigencia subjetiva -la "explotación" de la informaciónobstaba a esa operatividad; dado que su sustitución por la expresión "utilizar" en la DAM tuvo por objetivo evitar esos obstáculos ${ }^{157}$, debe partirse de la base de que la satisfacción de ese presupuesto se encuentra libre de requisitos subjetivos especiales ${ }^{158}$.

De estas consideraciones la Abogado General deduce dos máximas interpretativas:

"[U]na "utilización" no presupone ninguna decisión subjetiva de una persona de actuar precisamente a raíz de una información privilegiada de que disponga. El conocimiento de una información privilegiada no debe por tanto haber repercutido en la actuación en el sentido de una causalidad estricta, de una conditio sine qua non. No se exige que la persona no hubiera actuado sin la información privilegiada. ${ }^{159}$

$$
\text { (...) }
$$

$[\mathrm{U}]$ na actuación con conocimiento de una información privilegiada no constituye siempre e inevitablemente una operación prohibida con información privilegiada. En situaciones en las que esté excluido que el conocimiento de una información privilegiada pueda influir en la actuación, no podrá hablarse de utilización de información privilegiada." 160

Según la Abogada General, en el sentido preciso de la primera máxima -esto es, que no se requiere que la información sea causa psíquica necesaria de la operación- es que puede afirmarse que una actuación con conocimiento de la información privilegiada ya constituye una "utilización" en el sentido del art. 2-1 DAM ${ }^{161}$. No obstante, el mero conocimiento de la información no constituye necesariamente una utilización, en el sentido de que no siempre la implica. Los casos mencionados en el considerando $18^{\circ}$ DAM corresponden a situaciones en que la transparencia del mercado no está a priori amenazada, porque se excluye que la información influya en el comportamiento ${ }^{162}$. El hecho de que el art. 2-1 DAM prohíba una operación en la que se utilice información privilegiada y no se refiera a una actuación con conocimiento de la información permite entender excluidos de su ámbito de aplicación esos casos: en ellos "queda a priori excluido que la información influya en la actuación, de manera que no se puede hablar de una utilización de información privilegiada" $" 163$.

De todo lo anterior la Abogada General concluye que procede responder a la segunda cuestión prejudicial de la siguiente manera:

\footnotetext{
${ }^{157}$ La Abogada General se refiere aquí a los trabajos preparatorios analizados supra, sección 3.2.

${ }^{158}$ Op. cit. nota $n^{\circ} 153, \S \S 53-59$.

${ }^{159}$ Op. cit. nota $\mathrm{n}^{\circ} 153, \S 59$.

${ }^{160}$ Op. cit. nota $\mathrm{n}^{\circ} 153, \S 62$.

161 Op. cit. nota $\mathrm{n}^{\circ} 153, \S 61$.

162 Op. cit. nota ${ }^{\circ} 153, \S 63,64$. A estos casos se añadiría, según la Abogada General, el caso señalado por el Gobierno del Reino Unido, en el que se opera en un sentido inconsistente con la información poseída (pp. cit. $\S 66,67)$.

${ }^{163}$ Op. cit. nota $\mathrm{n}^{\circ} 153, \S 65$.
} 
BASCUÑÁN, Antonio. "Posesión, uso y explotación de la información privilegiada como elementos del insider trading en el derecho comparado del mercado de valores”.

"El artículo 2, apartado 1, de la Directiva 2003/6 debe interpretarse en el sentido de que el hecho de que una persona posea información privilegiada, sabiendo o debiendo saber que se trata de información privilegiada, y adquiera o ceda instrumentos financieros a los que se refiere dicha información, implica al mismo tiempo, por regla general, que esta persona "hace uso" de tal información. En circunstancias en las que está claro desde el principio que una información privilegiada no influye en la actuación de una persona, el mero conocimiento de una información privilegiada no implica al mismo tiempo que se hace uso de ella."164

El planteamiento de la Abogada General parece confundir el nivel de referencia de la interpretación de la formulación legal del supuesto de hecho con el nivel de referencia de la prueba de los hechos subsumibles en el supuesto legal. Es enteramente plausible que la formulación del art. 2-1 esté diseñada por el legislador europeo sobre la base de la razonable inferencia de que quien posee información privilegiada y opera en un sentido consistente con el conocimiento de esa información utiliza la información. Pero de eso no se deduce que el art. 2-1 deba ser interpretado en el sentido de que utilizar la información consista simplemente en operar en conocimiento de la misma. Asimismo, es enteramente plausible interpretar la expresión "utilizar" en un sentido tal que la descripción de la acción no exija que el conocimiento sea la única razón o motivo de la operación. Tal como la doctrina alemana dominante lo entiende respecto de un texto legal que pone énfasis en el uso de la información como elemento de la infracción ${ }^{165}$, para que haya utilización de la información en el sentido de la prohibición basta con que ella sea co-determinante de la operación $^{166}$. Pero de eso no se deduce que desde el punto de vista de la calificación jurídica la operación en posesión de información privilegiada "ya constituya" utilización de esa información.

La sentencia del ECJ en lo relativo a la segunda cuestión planteada por el tribunal requirente no es menos desconcertante que las observaciones de la Abogada General. Su decisión al respecto se contiene en el siguiente párrafo:

"[P]rocede responder a las cuestiones segunda y tercera que el artículo 2, apartado 1, de la Directiva 2003/6 debe interpretarse en el sentido de que el hecho de que una persona de las citadas en el párrafo segundo de esta disposición, que posea información privilegiada, adquiera o ceda, o intente adquirir o ceder, por cuenta propia o de terceros, directa o indirectamente, instrumentos financieros a que se refiera dicha información, implica que esta persona ha "utilizado esta información" en el sentido de dicha disposición, sin perjuicio del respeto del derecho de defensa y, en particular, del

\footnotetext{
${ }^{164}$ Op. cit. nota $\mathrm{n}^{\circ} 153, \S 69$. La respuesta a la segunda cuestión contiene implícita la respuesta a la tercera: "Mediante su tercera cuestión prejudicial, el órgano jurisdiccional remitente desea saber si se requiere una decisión deliberada o por escrito de utilizar la información privilegiada. A este respecto, puede remitirse en gran medida a las explicaciones relativas a la segunda cuestión prejudicial. Con la reformulación de la prohibición de operaciones con información privilegiada debía suprimirse del presupuesto de hecho cualquier elemento que hiciera referencia a un objetivo o a un propósito. Por consiguiente, no se requiere una decisión por escrito o deliberada de utilizar la información. Una persona no puede, en efecto, al actuar conociendo una información privilegiada, ignorarla completamente: Por lo contrario, la información influye, en general, en su decisión de compra o de venta. En consecuencia, procede considerar que existe, por regla general y sin más, utilización de la información privilegiada. No se requiere ninguna prueba adicional” (op. cit. § 70).

${ }^{165}$ Supra, nota $\mathrm{n}^{\circ} 145$.

${ }^{166}$ Supra, nota $\mathrm{n}^{\circ} 38$.
} 
Polít. crim. Vol. 12, No 23 (Julio 2017), Art. 13, pp. 453-532.

[http://www.politicacriminal.cl/Vol_12/n_23/Vol12N23A13.pdf]

derecho a poder destruir esta presunción. La cuestión de si dicha persona infringió la prohibición de operaciones con información privilegiada debe analizarse a la luz de la finalidad de esta Directiva, que es la de garantizar la integridad de los mercados financieros y aumentar la confianza de los inversores, que se basa, entre otras cosas, en la garantía de que estarán en igualdad de condiciones y de que estarán protegidos contra el uso ilícito de información privilegiada."167

Como se puede advertir, la decisión afirma en su primera parte una regla general y reconoce en su segunda parte una excepción. La regla general consiste en una inferencia: la realización de una operación en posesión de información privilegiada implica la utilización de la información en el sentido del art. 2-1 DAM. La excepción consiste en reconocer que la inferencia es refutable y que su refutación depende de demostrar que las circunstancias en que la operación es realizada ponen de manifiesto que ella no constituyó un atentado contra la finalidad de la directiva.

La decisión del ECJ es semejante en su estructura a la conclusión a que llega en sus observaciones la Abogado General ${ }^{168}$, aunque considerablemente más vaga y confusa. El ECJ destina 31 considerandos al razonamiento que justifica la decisión, que en lo esencial tiene la siguiente estructura argumentativa:

(i) Sobre la base de la comparación entre la formulación de prohibición por la DIT y por la DAM y la mención a los trabajos preparatorios de ésta última, el ECJ sostiene que el art. 2-1 DAM configura la infracción de modo exclusivamente objetivo: "no establece expresamente requisitos subjetivos relativos a la intención que inspiró [1]as acciones materiales", "no precisa si el poseedor primario de información privilegiada debió ser guiado por una intención especulativa, debió perseguir un propósito fraudulento o debió actuar deliberadamente o por negligencia", "no indica expresamente que sea necesario establecer que la información privilegiada determinó la decisión de efectuar la operación de mercado de que se trate, como tampoco prevé expresamente que el poseedor primario de información privilegiada debía ser consciente del carácter privilegiado de la información de que disponía",169.

(ii) Seguidamente el ECJ justifica esta descripción objetiva tomando en consideración la situación contextual de los insiders que tienen una responsabilidad fiduciaria respecto de la fuente de la información (art. 2-1 inciso segundo letras a), b) y c) DAM), el hecho de que las operaciones con instrumentos financieros excluyan por lo general una actuación sin que se sea consciente de los propios actos, la integración usual de la información en el proceso

${ }^{167}$ Sentencia del Tribunal de Justicia (Sala Tercera), de 23 de diciembre de 2009, en el asunto C-45/08, Spector Photo Group NV, Chris Van Raemdonck y Commissie voor het Bank-, Financie- en Assurantiewezen (CBFA), § 62. Disponible en: http://curia.europa.eu/juris/document/document.jsf?docid=77184\&doclang=ES (última consulta: 25.11.2016).

${ }^{168}$ El ECJ cita con aprobación las consideraciones de la Abogada General en los $\S \S 34$ y 37 de su sentencia.

${ }^{169}$ Op. cit. nota 30, $\S \S 30-35$. La referencia al "insider primario" se explica en función de la distinción que la DAM hace entre los insiders mencionados en el art. 2-1 inciso segundo (los primarios) y los demás poseedores de información privilegiada, a los cuales el art. 4 DAM considera destinatarios de las prohibiciones en la medida en que "esa persona sepa, o hubiera debido saber, que se trata de información privilegiada". Esta exigencia subjetiva no tiene equivalente respecto de los poseedores mencionados en el art. 2-1 DAM. 
BASCUÑÁN, Antonio. "Posesión, uso y explotación de la información privilegiada como elementos del insider trading en el derecho comparado del mercado de valores".

decisorio de quien realiza operaciones, y ante todo la finalidad del legislador europeo de formular una prohibición cuya aplicación fuera operativa para asegurar su eficacia ${ }^{170}$.

(iii) La conclusión que el ECJ deduce de las consideraciones anteriores es que "[1]a reunión de los elementos constitutivos de la operación con información privilegiada contemplados en el artículo 2, apartado 1, de la Directiva 2003/6 permite, por lo tanto, presumir la intención del autor de esta operación" ${ }^{\text {"171. }}$.

(iv) No obstante lo anterior, el ECJ sostiene que "[a]unque el artículo 2, apartado 1, de la Directiva 2003/6 no prevea expresamente un elemento subjetivo, ello no significa que deba interpretarse esta disposición en el sentido de que cualquier poseedor primario de información privilegiada que efectúe una operación de mercado entra automáticamente dentro del ámbito de aplicación de la prohibición de las operaciones con información privilegiada",172.

(v) La razón esta aparente contradicción la ve el ECJ en el hecho de que si bien "el establecimiento de un régimen eficaz y uniforme de prevención y de sanción de las operaciones con información privilegiada con el fin legítimo de proteger la integridad de los mercados financieros pudo así llevar al legislador comunitario a formular una definición objetiva de los elementos constitutivos de una operación prohibida con información privilegiada" ${ }^{173}$, esa definición objetiva -entiéndase: presunción de intención- no puede vulnerar el principio de presunción de inocencia del acusado, garantizado por las normas europeas sobre derechos humanos, que se extiende a las sanciones administrativas ${ }^{174}$. Ese principio no se opone a la existencia de presunciones, pero exige que sean refutables ${ }^{175}$.

(vi) La corrección de la interpretación extensiva asociada a la formulación objetiva de la prohibición debe hacerse según el ECJ atendiendo a la finalidad de la DAM, lo que lleva necesariamente a "distinguir las 'utilizaciones de información privilegiada' que pueden perjudicar dichos intereses de las que no pueden" $" 176$. Atendiendo a los considerandos $2^{\circ}$ y $12^{\circ}$ DAM y a jurisprudencia previa ${ }^{177}$, el ECJ identifica esos intereses como "la integridad de los mercados financieros y (...) la confianza de los inversores, confianza que se basa, entre otras cosas, en la garantía de que estarán en igualdad de condiciones y de que estarán protegidos contra el uso ilícito de información privilegiada"178 y "la igualdad entre las partes contractuales que intervienen en una operación bursátil, evitando que uno de ellos, poseedor de una información privilegiada que lo sitúa en una posición ventajosa con

\footnotetext{
${ }^{170}$ Sentencia cit. nota $\mathrm{n}^{\circ} 167, \S \S 36,37$.

${ }^{171}$ Sentencia cit. nota $\mathrm{n}^{\circ} 167, \S 38$.

${ }^{172}$ Sentencia cit. nota $\mathrm{n}^{\circ} 167, \S 45$.

173 Ibídem.

${ }^{174}$ Sentencia cit. nota $\mathrm{n}^{\circ} 167, \S \S 39-42$.

175 Sentencia cit. nota $n^{\circ} 167, \S \S 43,44$.

${ }^{176}$ Sentencia cit. nota $n^{\circ} 167, \S 46$.

${ }^{177}$ Sentencia del Tribunal de Justicia (Gran Sala), de 22 de noviembre de 2005, en el asunto C-384/02, contra Knud Grøngaard y Allan Bang, $\S \S 22,33$; sentencia de 10 de mayo de 2007, en el asunto C-391/04, Ipourgos Ikonomikon and Proistamenos DOY Amfissas v. Charilaos Georgakis, $\$ 38$.

${ }^{178}$ Sentencia cit. nota $\mathrm{n}^{\circ} 167, \S 47$.
} 
Polít. crim. Vol. 12, № 23 (Julio 2017), Art. 13, pp. 453-532.

[http://www.politicacriminal.cl/Vol_12/n_23/Vol12N23A13.pdf]

respecto a los otros inversores, saque provecho de ello en detrimento de la otra parte que desconoce tal información"179.

(vii) De la consideración de esas finalidades y la definición de la información privilegiada ${ }^{180}$, el ECJ concluye que "la prohibición de las operaciones con información privilegiada se aplica cuando un poseedor primario de información privilegiada hace una utilización indebida de la ventaja que le proporciona esta información efectuando una operación de mercado en consonancia con esta información" ${ }^{\text {"181. Y }}$. pese a que esta conclusión parece controvertir la inferencia afirmada antes, el ECJ sostiene paso seguido que de lo dicho "se desprende que el hecho de que un poseedor primario de información privilegiada efectúe una operación de mercado con los instrumentos financieros a los que se refiere esta información implica que dicha persona ha 'utilizado esta información' en el sentido del artículo 2, apartado 1, de la Directiva 2003/6, sin perjuicio del respeto del derecho de defensa y, en particular, del derecho a poder destruir esta presunción"

(viii) Junto con interpretar el art. 2-1 DAM como una presunción refutable, el ECJ advierte que para evitar una ampliación innecesaria e inapropiada del alcance de la prohibición "ciertas situaciones pueden requerir un examen en profundidad de los hechos que permita asegurarse de que la utilización de la información privilegiada reviste efectivamente el carácter indebido que dicha Directiva se propone proscribir en nombre de la integridad de los mercados financieros y de la confianza de los inversores"183. Tales situaciones se encuentran según el ECJ en los ejemplos proporcionados por los considerandos $18^{\circ}, 29^{\circ}$ y $30^{\circ} \mathrm{DAM}^{184}$. Estos ejemplos le permiten concluir, justo antes de dar su sentencia sobre los puntos 2 y 3 de la solicitud del Tribunal de Apelaciones de Bruselas, que:

[L]a cuestión de si un poseedor primario de información privilegiada 'utiliza esta información' en el sentido del artículo 2, apartado 1, de la Directiva 2003/6 debe determinarse a la luz de la finalidad de dicha Directiva, que consiste en garantizar la integridad de los mercados financieros y en aumentar la confianza de los inversores, confianza que se basa, entre otras cosas, en la garantía de que estarán en igualdad de condiciones y de que estarán protegidos contra el uso ilícito de información privilegiada. Sólo una utilización contraria a esta finalidad constituye una operación prohibida con información privilegiada." 185

Este es un razonamiento confuso ${ }^{186}$. En primer lugar, es obvio que el hecho de que la DAM no exija un especial elemento subjetivo del tipo referido al logro de un resultado ulterior en

\footnotetext{
${ }^{179}$ Sentencia cit. nota $\mathrm{n}^{\circ} 167, \S 48$.

${ }^{180}$ Sentencia cit. nota $n^{\circ} 167, \S \S 49-52$.

${ }^{181}$ Sentencia cit. nota $\mathrm{n}^{\circ} 167, \S 53$.

182 Sentencia cit. nota $n^{\circ} 167, \S 54$.

${ }^{183}$ Sentencia cit. nota $\mathrm{n}^{\circ} 167, \S 55$.

${ }^{184}$ Sentencia cit. nota $n^{\circ} 167, \S \S 56-59$.

${ }^{185}$ Sentencia cit. nota $\mathrm{n}^{\circ} 167, \S 61$.

186 BONNEAU describe la sentencia como una decisión "compleja en su motivación y [que] puede dar la impresión de tomar una posición muy matizada y por lo mismo difícil de poner en práctica" (BONNEAU, Thierry Régulation bancaire et financière européenne et internationale. Bruselas: Éditions Bruylant, $2^{\mathrm{a}}$ ed, 2014, p. 259 p. 259). Por el contrario, HANSEN entiende que tanto la opinión de la Abogado General como la
} 
BASCUÑÁN, Antonio. "Posesión, uso y explotación de la información privilegiada como elementos del insider trading en el derecho comparado del mercado de valores".

la descripción de la infracción no implica que la atribución de responsabilidad sancionatoria administrativa o penal prescinda o pueda prescindir por completo de la satisfacción de estándares de imputación subjetiva que exijan algún tipo de conocimiento actual o potencial referido a la posesión de información, a la naturaleza de la información poseída y a la operación realizada. La supresión de un elemento subjetivo específico no implica por lo tanto una presunción de intención. Al parecer el ECJ considera que la influencia de la información poseída en la motivación del agente, propia de la operación con "utilización" de la información, es equivalente a la existencia de esa tendencia interna trascendente consistente en "explotar" la información. Pero eso es excesivo, pues se puede formular una diferencia entre "explotar" y "utilizar" la información, tal como lo hace la Abogado General: la explotación presupone hacer de la información la razón necesaria, determinante o principal de la operación, lo que abre considerablemente el espectro de refutadores potenciales a su constatación. La utilización, en cambio, se satisface con la consistencia entre la información y la operación y su contribución acumulativa como razón o motivo de ésta. Por lo tanto, de la eliminación de la tendencia interna trascendente y sus estrictas exigencias de causalidad psíquica sólo cabe deducir que esas exigencias son improcedentes; pero no cabe deducir que las exigencias de causalidad psíquica que son procedentes de la descripción de la infracción como "utilización" de la información privilegiada se presumen satisfechas por la prueba de su posesión. Ciertamente, puede partirse de una presunción general de uso a partir de la prueba de la posesión y la operación, pero esa presunción no se deriva de la supresión de la exigencia de explotación de la información en la disposición, sino de una atribución de racionalidad económica a la acción.

También la correlación establecida entre la descripción "objetiva" de una infracción y la presunción simplemente legal de la concurrencia de determinados elementos subjetivos es confusa. Con su argumento el ECJ parece confundir la definición legal del supuesto de hecho de una norma sancionatoria o del frástico - el contenido proposicional- de una norma de comportamiento con la definición legal de la base de una inferencia o presunción. En rigor, hace de la consecuencia normativamente debida -la sanción- una consecuencia presumiblemente debida, sujeta a refutación. Con eso confunde el juicio que justifica la calificación deóntica de una acción, como acción prohibida, con el juicio que justifica la afirmación de su acaecimiento. Naturalmente, la calificación deóntica de una acción puede entenderse como calificación prima facie, es decir, provisoria porque está sujeta a revisión por consideraciones adicionales. La idea de que una regla admite excepciones implícitas es el principio básico de la teoría de la derrotabilidad (defeasibility) de las normas ${ }^{187}$. Que esas excepciones implícitas se entiendan pacíficamente como reglas especiales de aplicación preferente (autorizaciones excepcionales) o controvertidamente como reformulaciones correctivas del sentido literal de la disposición (interpretación restrictiva en sentido

sentencia del ECJ son claras en afirmar la estructura de POU de la prohibición establecida en la DAM, asumir una presunción de uso a partir de la posesión y atender a las situaciones en las que cabe revertir esa presunción (HANSEN, Jesper Lau, "What Constitutes Insider Dealing?: The Advocate General's opinion in Case 45/08, Spector Photo Group", International and Comparative Corporate Law Journal n 7 (2010), pp. 1-13; el mismo, "Insider Dealing Defined: The EU Court's Decision in Spector Photo Group" European Company Law $\mathrm{n}^{\circ} 7$ (2010), 98-105).

${ }^{187}$ FERRER BELTRÁN, Jordi, RATTI, Giovanni B., "Validity and Defeasibility in the Legal Domain", Law and Philosophy $\mathrm{n}^{\circ} 29$ (2010), pp. 601-626. 
Polít. crim. Vol. 12, No 23 (Julio 2017), Art. 13, pp. 453-532.

[http://www.politicacriminal.cl/Vol_12/n_23/Vol12N23A13.pdf]

metodológico) ${ }^{188}$ depende básicamente del grado de desarrollo sistemático del derecho legislado y de la cultura jurídica. Pero la derrotabilidad de la calificación deóntica, o también de la imputación de la consecuencia jurídica como consecuencia debida, no es lo mismo que la refutabilidad de una presunción. La presunción es una regla de inferencia que justifica la verdad de la afirmación de acaecieron los hechos subsumibles bajo el supuesto de hecho de la norma (i.e., los hechos directamente relevantes para la calificación jurídica) como consecuencia de la verdad de la afirmación de que acaecieron otros hechos, no subsumibles bajo ese supuesto de hecho (i.e., no directamente relevantes para la calificación jurídica). Por eso, toda presunción -regla de inferencia- presupone una norma que configura un supuesto de hecho, ya sea una norma de comportamiento o de sanción. Si el art. 2-1 DAM tiene el carácter de una presunción, entonces se plantea la pregunta de cuál es la disposición que contiene la norma que configura el supuesto de hecho de la prohibición de insider trading. Obviamente, en la DAM esa disposición no puede ser otra que el art. 2-1. Pero una misma disposición no puede ser simultáneamente norma de comportamiento y regla de inferencia respecto del mismo hecho.

Es posible que el carácter indirecto del art. 2-1 DAM como norma de comportamiento -es una orden a los Estados de establecer una prohibición, así como el art. 13 DAM es una orden de establecer una sanción para la infracción de la prohibición- explique la confusión de niveles de análisis en la sentencia del ECJ. En este sentido, lo que el ECJ sostiene es que la orden de la DAM debe entenderse como compatible con una presunción de uso a partir de la posesión, lo que validaría el establecimiento por un Estado de una POP, siempre que esa presunción sea refutable, lo cual a su vez exigiría de ese Estado el reconocimiento de excepciones a la POP. Eso implicaría que la respuesta dada por el ECJ a la cuestión 2 planteada por el Tribunal de Apelaciones de Bruselas consistió en validar la regulación belga que entró en vigencia el $1^{\circ}$ de enero de 2004, en contra del planteamiento de los requirentes ante ese tribunal.

Naturalmente, la formulación de esta tesis en el lenguaje de una presunción refutable no sólo es confusa, sino que pone a la decisión del ECJ en tensión con la presunción de inocencia garantizada por el art. 6 del Convenio Europeo de Derechos Humanos. Como se ha visto, el ECJ estima que esa tensión se encuentra suficientemente contenida por el hecho de admitirse la refutabilidad de la presunción. Pero un sector de la doctrina alemana ha argumentado en contra de esa consideración que si se trata de una presunción vinculante para el tribunal, es decir, una presunción que lo obliga a dar por probada la utilización a

\footnotetext{
${ }^{188}$ Una interpretación puede ser extensiva o restrictiva en sentido analítico o serlo en sentido metodológico. En sentido analítico, que es también el sentido general, una propuesta interpretativa es extensiva o restrictiva por comparación con otra propuesta interpretativa, que por definición es correlativamente restrictiva o extensiva. En sentido metodológico, que es un sentido teórico especial, la interpretación extensiva o restrictiva es la que se justifica por razones pragmáticas (sistemáticas, teleológicas) por comparación con el sentido lingüístico (tenor literal) de la disposición. Dicho con la terminología europea de los siglos XVIII, XVIII y la primera mitad del siglo a XIX, la interpretación extensiva o restrictiva es la que resulta de constatar una discordancia entre la interpretación gramatical (i.e., conforme a criterios lingüísticos) y la interpretación lógica (i.e., conforme a criterios pragmáticos) y atribuir preponderancia a la segunda.
} 
BASCUÑÁN, Antonio. "Posesión, uso y explotación de la información privilegiada como elementos del insider trading en el derecho comparado del mercado de valores".

partir de la prueba de la posesión a menos que el acusado la refute, ella genera una alteración de la carga de la prueba que es incompatible con la presunción de inocencia ${ }^{189}$.

Como sea, en sus resultados la tesis del ECJ puede enunciarse así: la DAM prohíbe la operación con información privilegiada -establece una PO-; es operación con información privilegiada la realizada en posesión de información privilegiada -la $\mathrm{PO}$ es una $\mathrm{POP}-$, a menos que el acusado demuestre lo contrario y siempre que las circunstancias del hecho no pongan de manifiesto que no constituye un atentado contra los fines perseguidos por su prohibición, que garantiza protección contra el uso de información privilegiada por sus poseedores - contra la infracción a una POU-. Cualquiera que sea la naturaleza que se reconozca a la regla general y a las excepciones formuladas por el ECJ lo único claro es que éste atribuye al art. 2-1 DAM, en tanto POP, el carácter de una prohibición prima facie sobreinclusiva. La sobreinclusividad de la prohibición se deja justificar por razones prácticas, siempre y cuando se admita que ella pueda ser derrotada, ya sea mediante consideraciones fácticas (refutación de la presunción) o teleológico-sistemáticas (interpretación restrictiva).

\subsection{El Reglamento (UE) 596/2014 del Parlamento Europeo y el Consejo, de 16 de abril de $2014^{190}$.}

El RAM regula el insider trading en sus artículos 8-1 y $14^{191}$ :

“Art. 8. Operaciones con información privilegiada. 1. A efectos del presente Reglamento, las operaciones con información privilegiada son las realizadas por una persona que dispone de información privilegiada y que la utiliza adquiriendo, transmitiendo o cediendo, por cuenta propia o de terceros, directa o indirectamente, los instrumentos financieros a los que se refiere esa información. Se considerará asimismo como operación con información privilegiada la utilización de este tipo de información cancelando o modificando una orden relativa al instrumento financiero al que se refiere la información, cuando se hubiese dado la orden antes de que el interesado tuviera

\footnotetext{
189 OPITZ, “Anmerkung”, cit. nota n 135; GERHMAN, Philipp, "Das Spector-Urteil des EuGH - Zur Beweislastumkehr beim Insiderhandel Beweislastumkehr beim Insiderhandel”, Zeitschrift für Bankrecht und Bankwirtschaft $\mathrm{n}^{\circ}$ 10-1 (2010), pp. 48-52; SEREDYNSKA, Insider Dealing, cit. nota $\mathrm{n}^{\circ}$ 135, p. 26. En contra, sosteniendo su compatibilidad con el derecho alemán, KÖHLER, "Wertpapierhandelsgesetz", cit. nota $\mathrm{n}^{\circ} 34, \S 8 \mathrm{~nm}$. 142. En una posición intermedia, identificando dificultades procesales pero considerándolas superables, BEGEMEIER, Moritz, "Zur Reichweite der unionsrechtskonformen Auslegung im deutschen Straf- und Strafverfahrensrecht am Beispiel der 'Spector Photo Group'-Entscheidung des EuGH”, 2013-5 Onlinezeitschrift für Hochsrichterliche Rechtsprechung zum Strafrecht (2013), pp. 179-186.

${ }^{190}$ Al respecto: MOLONEY, EU Securities, cit. nota $n^{\circ} 120$, pp. 727-728; BONNEAU, Régulation bancaire, cit. nota $\mathrm{n}^{\circ}$ 186, pp. 249-262. Las distintas versiones idiomáticas del Reglamento se encuentran disponibles en:

http://eur-lex.europa.eu/legal-content/ES/TXT/?uri=uriserv:OJ.L_.2014.173.01.0001.01.SPA

(última consulta: 25.11 .2016$)$.

${ }^{191}$ El RAM es complementado por la Directiva 2014/57/UE, del Parlamento Europeo y del Consejo, de 16 de abril de 2014, sobre las sanciones penales aplicables al abuso de mercado. Disponible en: http://eurlex.europa.eu/legal-content/ES/TXT/?uri=CELEX:32014L0057 (última consulta: 25.11.2016). El art. 3-2 de la Directiva reproduce la definición básica de operación con información privilegiada del Art. 8-1 RAM: "2. A efectos de la presente Directiva, las operaciones con información privilegiada son las realizadas por una persona que dispone de información privilegiada y que la utiliza adquiriendo, transmitiendo o cediendo, por cuenta propia o de terceros, directa o indirectamente, los instrumentos financieros a los que se refiere esa información.”
} 
Polít. crim. Vol. 12, No 23 (Julio 2017), Art. 13, pp. 453-532.

[http://www.politicacriminal.cl/Vol_12/n_23/Vol12N23A13.pdf]

conocimiento de la información privilegiada. En relación con las subastas de derechos de emisión u otros productos subastados basados en esos derechos, celebradas de conformidad con el Reglamento (UE) $\mathrm{N}^{\circ}$ 1031/2010, la utilización de información privilegiada incluye asimismo la presentación, modificación o retirada de una oferta por una persona tanto cuando actúe por cuenta propia como de terceros."

“Art. 14. Prohibición de las operaciones con información privilegiada (...). Ninguna persona podrá:

a) realizar o intentar realizar operaciones con información privilegiada; (...)"

Como se puede apreciar, el RAM hace ilícita no sólo la infracción consumada, sino también la infracción tentada, y expresamente incluye la cancelación y modificación de órdenes dentro de la prohibición, equiparándola a la realización de una operación. Por otra parte, el RAM conserva la ambivalencia de la formulación de la prohibición que exhibía la DAM: según como se interprete la sintaxis de la disposición, la acción descrita como "utilización de la información" puede ser entendida como un modo de comisión de la acción de realizar una operación o diluirse en esta segunda acción ${ }^{192}$. Es decir, establece una prohibición que es ambigua respecto del estándar utilizado, si posesión o uso. La solución que el RAM da a este problema no se encuentra en la formulación de la prohibición sino en su régimen de excepciones.

El art. 9 RAM contempla el catálogo más extenso y detallado de excepciones a la prohibición de insider trading que ha conocido el derecho común europeo, ahora calificadas como "conducta legítima". Tal como lo observa una autora ${ }^{193}$, muchas de estas excepciones fueron reconocidas previamente por la DIT y la DAM, ya sea en el nivel de sus disposiciones o de los considerandos de su preámbulo, por lo que la nueva regulación no constituye un cambio o transformación del derecho común, aunque sin duda ofrece un mayor nivel de certeza. El art. 9 RAM enumera cinco excepciones:

(i) el art. 9-1 contempla la excepción de la persona jurídica que presta servicios múltiples de asesoría financiera ${ }^{194}$;

(ii) el art. 9-2 contempla le excepción de la actuación regular de agentes de mercado ${ }^{195}$;

\footnotetext{
${ }^{192}$ Ciertamente, el art. 8-1 RAM distingue de modo nítido entre la acción de poseer (disponer de) información y la acción de utilizar información. La dificultad radica en que esa distinción puede equivaler a la diferencia entre poseer información y realizar una operación poseyendo información. Con todo, una consideración contextual puede inferir de la distinción entre poseer y usar la necesidad de una distinción equivalente entre realizar una operación poseyendo información privilegiada y realizarla utilizando información privilegiada. MOLONEY advierte en el art. 8-1 RAM la probable necesidad de una "calificación causal" (EU Securities, cit. nota $\mathrm{n}^{\circ} 120$, p. 727).

${ }^{193}$ MOLONEY, EU Securities, cit. nota $\mathrm{n}^{\circ} 120$, p. 727.

194 “Art. 9. Conducta legítima. 1. A efectos de lo dispuesto en los artículos 8 y 14, del mero hecho de que una persona jurídica posea o haya poseído información privilegiada no se considerará que la haya utilizado y que, por lo tanto, haya realizado operaciones con información privilegiada en relación con alguna adquisición, transmisión o cesión, siempre que esa persona jurídica: / a) haya establecido, aplicado y mantenido mecanismos y procedimientos internos adecuados y eficaces que garantizan eficazmente que ni la persona física que adoptó en su nombre la decisión de adquirir, transmitir o ceder los instrumentos financieros a los que se refiere la información, ni ninguna otra persona física que pueda haber influido en dicha decisión, estaba en posesión de la información privilegiada, y / b) no haya alentado, recomendado o inducido a la persona física que, por cuenta de la persona jurídica, adquirió, transmitió o cedió los instrumentos financieros a los que se refiere la información, o no haya influido en esa persona física por cualquier otro medio."
} 
BASCUÑÁN, Antonio. "Posesión, uso y explotación de la información privilegiada como elementos del insider trading en el derecho comparado del mercado de valores".

(iii) el art. 9-3 contempla la excepción del plan u obligación previa ${ }^{196}$;

(iv) el art. 9-4 contempla una excepción para el due diligence que precede a la toma de control o fusión ${ }^{197}$;

(v) el art. 9-5 contempla la excepción del conocimiento sobre la propia decisión de $\operatorname{operar}^{198}$.

Todas las excepciones están sometidas a una exigencia general de actuación de buena fe, que otorga competencia a las autoridades estatales para negar el carácter de conducta legítima en caso de no ser satisfecha (art. 9-6) ${ }^{199}$.

Además del art. 9 el RAM contempla otras disposiciones destinadas a proteger al poseedor de información privilegiada del riesgo de infringir la prohibición de insider trading, como la referida a la intervención de la autoridad monetaria ${ }^{200}$ y la referida a la implementación de programas de recompra y estabilización de los propios valores por los emisores ${ }^{201}$.

Tal como la R 10b-51(c) SEC, la redacción del art. 9 RAM expresa la apreciación de que en estos casos no hay utilización de la información pese a realizarse una operación en

195 “Art. 9. Conducta legítima. (...) 2. A efectos de lo dispuesto en los artículos 8 y 14, del mero hecho de que una persona posea información privilegiada no se considerará que la haya utilizado y que, por lo tanto, haya realizado operaciones con información privilegiada en relación con alguna adquisición, transmisión o cesión, siempre que dicha persona: / a) por lo que respecta al instrumento financiero al que se refiere dicha información, sea un creador de mercado o una persona autorizada para actuar como contraparte, y la adquisición, transmisión o cesión de los instrumentos financieros a los que se refiere dicha información se realice de forma legítima en el curso normal del ejercicio de su función como creador de mercado o como contraparte en relación con dicho instrumento financiero, o / b) esté autorizada a ejecutar órdenes por cuenta de terceros, y la adquisición, transmisión o cesión de los instrumentos financieros a los que se refiere la orden se realice de forma legítima en el curso normal del ejercicio de su trabajo, profesión o funciones." La excepción constaba en el considerando $12^{\circ}$ DIT y corresponde al considerando $30^{\circ} \mathrm{RAM}$.

${ }^{196}$ Infra, sección 3.5.

197 “Art. 9. Conducta legítima. (...) 4. A efectos de lo dispuesto en los artículos 8 y 14, del mero hecho de que una persona posea información privilegiada no se considerará que la haya utilizado y que, por lo tanto, haya realizado operaciones con información privilegiada, siempre que dicha persona haya obtenido esa información privilegiada en el transcurso de una oferta pública de adquisición o fusión con una empresa y utilice dicha información privilegiada con el mero objeto de llevar a cabo esa fusión u oferta pública de adquisición, siempre que en el momento de la aprobación de la fusión o aceptación de la oferta por los accionistas de la empresa en cuestión toda información privilegiada se haya hecho pública o haya dejado de ser información privilegiada. / El presente apartado no se aplicará a la formación de una participación." La excepción constaba en el considerando $29^{\circ}$ DAM y corresponde al considerando $31^{\circ} \mathrm{RAM}$.

198 “Art. 9. Conducta legítima. (...) 5. A efectos de lo dispuesto en los artículos 8 y 14, el mero hecho de que una persona utilice su propio conocimiento de que ha decidido adquirir, transmitir o ceder instrumentos financieros en la adquisición, transmisión o cesión de dichos instrumentos financieros no constituirá en sí mismo utilización de información privilegiada." La excepción constaba en el considerando $11^{\circ}$ DIT y en el considerando $30^{\circ} \mathrm{DAM}$

199 “Art. 9. Conducta legítima. (...) 6. No obstante lo dispuesto en los apartados 1 a 5 del presente artículo, también podrá considerarse que se ha infringido la prohibición de operar con información privilegiada establecida en el artículo 14 si la autoridad competente determina que tras esas operaciones, órdenes de negociación o conductas no hubo razones legítimas.

${ }^{200}$ Art. $6^{\circ}$ RAM, correspondiente al art. 2-4 DIT y al considerando $32^{\circ} \mathrm{y}$ al art. 7 DAM.

${ }^{201}$ Considerandos $11^{\circ}, 12^{\circ}$ y $84^{\circ}$ y art. $5^{\circ}$ RAM, correspondientes al considerando $33^{\circ}$ y al art. 8 DAM. Los programas de recompra se encuentran regulados por los arts. 21 a 27 de la Directiva 2012/30/UE del Parlamento Europeo y del Consejo. 
Polít. crim. Vol. 12, No 23 (Julio 2017), Art. 13, pp. 453-532.

[http://www.politicacriminal.cl/Vol_12/n_23/Vol12N23A13.pdf]

posesión de información privilegiada. Dado que el art. 8-1 no es equivalente a la Regla 10b5-1(b) SEC, pues no formula explícitamente una definición del estándar de uso como estándar de posesión, se tiene que en el contexto del RAM resulta enteramente plausible la tesis de que el catálogo de excepciones contemplado en el art. 9 no es exhaustivo. Es decir, puede postularse que el RAM acepta una defensa negativa general consistente en que no se utilizó la información poseída en la realización de la operación. Con todo la defensa debería satisfacer dos restricciones:

(i) conforme a la interpretación del elemento "utilizar" en la doctrina alemana, no constituye defensa suficiente la mera alusión a razones o motivaciones personales distintas del aprovechamiento de la información; es necesario demostrar que el conocimiento de la información no contribuyó como razón o motivo de la decisión;

(ii) conforme al precedente sentado por el ECJ en el caso Spector no parece ser suficiente la mera alusión a circunstancias fácticas particulares, sino que parece ser necesario relacionar esas circunstancias con un fundamento normativo de la operación que sea consistente con la finalidad de protección de la prohibición del insider trading, demostrando que la operación no atenta contra esa finalidad.

En sus resultados, pues, esta interpretación atribuye al RAM la adopción de un estándar modificado de uso. Esto es consistente con la comprensión que el legislador europeo tiene de la regulación, como se explica en la sección siguiente.

\subsection{La defensa del plan previo.}

\subsubsection{En el art. 9-3(a) RAM.}

El art. 9-3 RAM reconoce como conducta legítima la operación en posesión de información privilegiada que se realiza conforme a un plan previo. En sus propios términos:

"Art. 9. Conducta legítima. (...)

3. A efectos de lo dispuesto en los artículos 8 y 14, del mero hecho de que una persona posea información privilegiada no se considerará que la haya utilizado y que, por lo tanto, haya realizado operaciones con información privilegiada en relación con alguna adquisición, transmisión o cesión, siempre que dicha persona realice una operación para adquirir, transmitir o ceder instrumentos financieros y esta operación se efectúe de buena fe en cumplimiento de una obligación vencida y no para eludir la prohibición de operaciones con información privilegiada, y:

a) dicha obligación se derive de una orden dada o de un acuerdo celebrado antes de que la persona en cuestión tuviera conocimiento de la información privilegiada, o

b) esa operación tenga por objeto cumplir una disposición legal o reglamentaria anterior a la fecha en que la persona en cuestión tuviera conocimiento de la información privilegiada."

La defensa del plan previo, consignada en la letra a) del art. 9-3 RAM tiene antecedentes en la $\operatorname{DIT}^{202}$ y la $\mathrm{DAM}^{203}$ y se encuentra en el núcleo de la concepción que el legislador

\footnotetext{
${ }^{202}$ Considerando $12^{\circ}$, en lo relativo al mandatario.

203 Art. 2-3: “3. El presente artículo no se aplicará a las transacciones realizadas en cumplimiento de una obligación, ya vencida, de adquirir o ceder instrumentos financieros, cuando esta obligación esté contemplada
} 
BASCUÑÁN, Antonio. "Posesión, uso y explotación de la información privilegiada como elementos del insider trading en el derecho comparado del mercado de valores".

europeo tiene del sentido y alcance de la prohibición del insider trading. Esto queda de manifiesto en los considerandos $23^{\circ}, 24^{\circ}$ y $25^{\circ}$ de su preámbulo:

“(23) La característica esencial de la operación con información privilegiada consiste en obtener una ventaja injusta a partir de información privilegiada en detrimento de terceros que desconocen la información y, por tanto, en el menoscabo de la integridad de los mercados financieros y la confianza de los inversores. Por consiguiente, la prohibición de operar con información privilegiada debe ser aplicable cuando una persona que posee información privilegiada obtiene una ventaja injusta del beneficio conseguido a partir de dicha información al efectuarse operaciones de mercado sobre la base de dicha información, ya se trate de una adquisición, transmisión o cesión, o de un intento de adquisición, transmisión o cesión, o de una cancelación o modificación, de un intento de cancelación o modificación, de una orden para adquirir, transmitir o ceder, por cuenta propia o de terceros, directa o indirectamente, instrumentos financieros a los que se refiere la información en cuestión. La utilización de información privilegiada puede consistir asimismo en el comercio de derechos de emisión y sus derivados, así como en la participación en subastas de derechos de emisión u otros productos subastados basados en los mismos, celebradas de conformidad con el Reglamento (UE) n o 1031/2010 de la Comisión.

(24) Cuando una persona física o jurídica que posee información privilegiada adquiere, transmite o cede, o intenta adquirir, transmitir o ceder, por cuenta propia o de terceros, directa o indirectamente, instrumentos financieros a los que se refiere dicha información, ha de suponerse que esa persona ha utilizado dicha información. Esta presunción se entiende sin perjuicio del derecho de defensa. La cuestión de si una persona ha infringido la prohibición de realizar operaciones con información privilegiada o ha intentado realizarlas ha de analizarse teniendo en cuenta el objeto del presente Reglamento, que es proteger la integridad de los mercados financieros y aumentar la confianza de los inversores, lo que, a su vez, se basa en la garantía de que estos estarán en igualdad de condiciones y protegidos contra una utilización indebida de información privilegiada.

(25) Las órdenes formuladas antes de que una persona posea información privilegiada no deben tener la consideración de operaciones con información privilegiada. Sin embargo, cuando una persona tiene conocimiento de información privilegiada, debe presumirse que cualquier cambio basado en esa información, que afecte a órdenes dadas antes de conocerla, incluidas la cancelación o modificación y la tentativa de hacerlo, constituye una operación con información privilegiada. No obstante, dicha presunción podrá ser refutada si la persona demuestra que no ha utilizado información privilegiada al realizar la operación."

Estos tres considerandos ofrecen una concepción consistente y exhaustiva de la prohibición del insider trading en términos tales que implican la licitud de la operación en cumplimiento de una orden previa a la posesión de información privilegiada, aunque posteriormente se haya entrado en posesión de información. Lo primero que cabe destacar es que la finalidad de la prohibición se encuentra en la evitación de la ventaja injusta ("unfair advantage") proveniente de la información privilegiada. Es esa ventaja lo que atenta contra la confianza en la integridad del mercado de valores. La naturaleza de esa ventaja se encuentra en que la operación se pueda entender como basada en la información,

en un acuerdo celebrado antes de que la persona de que se trate esté en posesión de la información privilegiada." 
Polít. crim. Vol. 12, No 23 (Julio 2017), Art. 13, pp. 453-532.

[http://www.politicacriminal.cl/Vol_12/n_23/Vol12N23A13.pdf]

no como su causa necesaria, sino como una razón o motivo consistente con su realización ${ }^{204}$. Esa consistencia entre información y operación permite presumir el uso. La presunción puede no obstante ser refutada, tomando en consideración la congruencia de la operación y sus circunstancias con la finalidad de la regulación. La ejecución de órdenes previas a la posesión de información no con casos de operación con información privilegiada, porque no implican una ventaja injusta. Eso vale siempre y cuando el emitente de la orden no interfiera en su ejecución una vez que entra en posesión de la información. Cualquier cambio relacionado con esa información ${ }^{205}$, incluida la cancelación, constituye operación con información privilegiada. No obstante, tal como sucede con la ejecución de la operación, su cancelación también puede demostrar que ha tenido lugar sin uso de información privilegiada.

\subsubsection{En los Estados miembros de la Unión Europea.}

La defensa establecida en el art. 9-3(a) RAM es conocida también en el derecho de los Estados miembros de la Unión Europea vigente con anterioridad al RAM.

En el derecho alemán vigente a partir de 2004 (supra, sección 4.2) la defensa de la orden previa se entiende como defensa negativa relacionada con la concurrencia del elemento de la utilización de la información privilegiada. La doctrina trata la defensa del plan previo en relación con la determinación del momento en que ha de usarse la información para incurrir en infracción de la prohibición, y sostiene en forma absolutamente dominante que en los casos en que se imparte y ejecuta una orden dicho momento corresponde al hecho de impartirla $^{206}$.

En el Reino Unido, tanto la regulación penal como la regulación administrativa la reconocen expresamente. Tratándose de la regulación penal la $\S 53$ CJA establece las siguientes defensas;

"§ 53. Defences.

(1) An individual is not guilty of insider dealing by virtue of dealing in securities if he shows-

(a) that he did not at the time expect the dealing to result in a profit attributable to the fact that the information in question was price-sensitive information in relation to the securities, or

\footnotetext{
${ }^{204}$ La expresión "sobre la base de", consignada en el considerando $23^{\circ}$ RAM en su versión en español, equivalente a la expresión italiana "basate su", a la expresión portuguesa "com base na" y a la expresión alemana "aufgrund", debe ser concordada con la expresión inglesa "in accordance with" y la expresión francesa "conformément à".

${ }^{205}$ La expresión "basado en", consignada en el considerando $25^{\circ}$ RAM de su versión en español debe ser concordada con la expresión portuguesa "que lige a", la expresión italiana "riguardante a", la expresión inglesa "relating", la expresión alemana "im Zusammenhang stehen mit" y la expresión francesa "reliant".

${ }^{206}$ La doctrina del momento de la posesión se entiende como deducción del requisito de causalidad psíquica; HOPT, "Problemática", cit. nota $\mathrm{n}^{\circ}$ 34, pp. 477-478; PANANIS "Wertpapierhandelsgesetz", cit. nota $\mathrm{n}^{\circ} 34$, nm. 66; SETHE, "Insiderrecht", cit. nota $\mathrm{n}^{\circ} 34, \mathrm{~nm}$. 97. El argumento es transferible al derecho italiano, donde la doctrina también entiende que el elemento "utilizando" requiere un verdadero nexo causal entre la posesión de la información privilegiada y la realización de la operación (ZANOTTI, Roberto, Il nuovo diritto penale dell'economia. Milán: Giuffrè, 2008, p. 410).
} 
BASCUÑÁN, Antonio. "Posesión, uso y explotación de la información privilegiada como elementos del insider trading en el derecho comparado del mercado de valores".

(b) that at the time he believed on reasonable grounds that the information had been disclosed widely enough to ensure that none of those taking part in the dealing would be prejudiced by not having the information, or

(c) that he would have done what he did even if he had not had the information. (...)"

Como se puede apreciar, las defensas $\S 53(1)(a)$ y $\S 53(1)(b)$ se relacionan con las propiedades de la información poseída o de su apreciación por el agente. La defensa $\S$ 53(1)(c), en cambio, corresponde a la falta de conexión de sentido (causalidad o estado mental correlativo) de una información que reúne todas las propiedades y la operación realizada en posesión de la misma. Esta defensa naturalmente comprende el caso de la orden previa $^{207}$.

La FSMA no contempla defensas, pero la Sección 1.3.3. del MAR 1 establecido por la FSA del Reino Unido, actualmente FCA, declaró explícitamente que la orden previa no constituye operación "sobre la base de" información privilegiada en el sentido del art. 188 FMSA:

"Factors to be taken into account: "on the basis of"

In the opinion of the FCA, the following factors are to be taken into account in determining whether or not a person's behaviour is 'on the basis of' inside information, and are each indications that it is not:

(1) if the decision to deal or attempt to deal was made before the person possessed the relevant inside information; or

(2) if the person concerned is dealing to satisfy a legal or regulatory obligation which came into being before he possessed the relevant inside information; (...)"208

Finalmente, en España la defensa del plan previo es reconocida como defensa negativa respecto de la regulación penal, en un sentido similar al de la doctrina alemana, y como defensa afirmativa respecto de la regulación administrativa. A su examen se encuentra dedicada la siguiente sección. Antes de pasar a ello conviene dedicar una breve mención a la regulación francesa.

\footnotetext{
${ }^{207}$ WOTHERSPOON, Keith, "Insider Dealing - The New Law: Part V of the Criminal Justice Act 1993", The Modern Law Review n 57 (1994), pp. 419-433, pp. 430 y ss.; CLARKE, Insider Dealing, cit. nota n 144, pp. 123-124, citando casos de absolución por haber vendido acciones bajo la errónea suposición de estar en un deber contractual de hacerlo debido al retiro de una posición de insider ( $R$ v Cross [1990] 1 Cr App R 115) y por hacer un regalo al recién nacido de un ahijado $(R v$ Stebbing, unreported, citado por Accountancy, Sept 1991, 12); en $R v$ Mustafa an others, un caso con condenas por 6 cargos de insider trading, el juez instruyó al jurado en el sentido de que la defensa no supone prueba de falta de consideración de la información privilegiada antes de la operación, sino de que es más probable que improbable que el acusado tenía una intención formada de realizar la operación y que lo habría hecho del mismo modo incluso si no hubiera poseído la información (op. cit. loc. cit.).

${ }_{208} \mathrm{La}$ regla se encontraba disponible en: http://www.fca.org.uk/firms/markets/market-abuse/marketconduct.en (última consulta 06.03.2015). Al respecto, CLARKE, Insider Dealing, cit. nota $\mathrm{n}^{\circ}$ 144, pp. 187188, citando casos en que la defensa alegada fue desechada por falta de prueba suficiente. En la actualidad la FCA se remite a los arts. 8 y 9 RAM:

https://www.handbook.fca.org.uk/handbook/MAR/1/3.pdf, https://www.fca.org.uk/publication/policy/ps1613.pdf (última consulta: 25.11.2016) y
} 
Polít. crim. Vol. 12, No 23 (Julio 2017), Art. 13, pp. 453-532.

[http://www.politicacriminal.cl/Vol_12/n_23/Vol12N23A13.pdf]

\subsubsection{El caso de Francia ${ }^{209}$.}

La primera regulación sancionatoria del insider trading ("operación de iniciados") en Francia fue de carácter penal. La estableció la Ley $\mathrm{N}^{\circ}$ 70-128, de 23 de diciembre de 1970, introduciendo un art. 10-1 de la Ordenanza $N^{\circ}$ 67-833, de 28 de septiembre de $1967^{210}$. Esta disposición tipificaba el delito de insider trading como una operación realizada explotando la información. La regulación fue modificada por la Ley 83-1, de 3 de enero de 1983, 85.1321, de 14 de diciembre de 1985, y la Ley 88-70, de 22 de enero de 1988. La reforma legal de 1983 sustituyó la exigencia de explotación de la información privilegiada por el requisito de que la operación fuera realizada "sobre el fundamento" de la información $^{211}$. La reforma legal de 1988 dio al tipo del delito la estructura de una operación en posesión de información privilegiada ${ }^{212}$. Esta regulación penal fue

${ }^{209}$ IRVING, Robert B., "French Insider Trading Law: A Survey", The University of Miami Inter-American Law Review $\mathrm{n}^{\circ} 22$ (1990), pp. 41-73; PETERSEN, Patricia, "Insider Trading in Frances: beefing up the COB", International Finance Law Review n' 9 (1990), pp. 32-36; GIUDICELLI-DELAGE, Genevieve, "El delito de iniciados en el derecho francés", en: ARROYO ZAPATERO, Luis et al, Hacia un Derecho Penal Econímico. Jornadas en Honor del Profesor Klaus Tiedemann. Madrid: Boletín Oficial del Estado, 1995, pp. 401-410; UMHOEFER, Carol, PIÉTRANCOSTA, Alain, "Le Délit d'Initié: Insider Trading in France", Columbia Journal of Transnational Law n 30 (1992), pp. 89-144; HERNÁNDEZ SAINZ, Esther, "La prohibición de los abusos de información privilegiada en el derecho del mercado de valores francés", $\underline{\text { Revista }}$ de derecho bancario y bursátil $n^{\circ} 71$ (1998), pp. 747-814; WELCH et al, Comparative Implementation, cit. nota $\mathrm{n}^{\circ}$ 142; LASSERRE CAPDEVILLE, Jérôme, "Le délit d'initié: une infraction modelée par les juges", Actualité Juridique Pénal 2011-2, pp. 58-60; PONS-HENRY, Jean Philippe, “Opérations d'inititiés: puisque le manquement se délite, supprimons le délit”, Bulletin Joly Bourse 2011-mars, pp. 211-217.

210 "Seront punies d'un emprisonnement de deux mois à deux ans et d'une amende de 5000 à 5 millions de francs dont le montant pourra être porté au-delà de ce chiffre jusqu'au quadruple du montant du gain éventuellement réalisé ou de l'une de ces deux peines seulement, les personnes mentionnées à l'article 162-1 de la loi n 66-537 du 24 juillet 1966 ainsi que toutes autres personnes disposant, à l'occasion de l'exercice de leur profession ou de leurs fonctions, d'informations privilégiées sur la marche technique, commerciale et financière d'une société, qui auront réalisé sur le marché boursier, soit directement, soit par interposition de personnes, une ou plusieurs opérations en exploitant lesdites informations avant que le public en ait connaissance". Disponible en:

http://www.legifrance.gouv.fr/affichTexteArticle.do;jsessionid=C0F7ABDE040576FA29A8D0E5C6152365.t pdila10v_3?cidTexte=JORFTEXT000000698676\&idArticle=LEGIARTI000006778311\&dateTexte $=2015031$ 5\&categorieLien=id\#LEGIARTI000006778311 (última consulta: 25.11.2016). Con anterioridad al establecimiento de esta disposición el derecho francés sólo conocía una regla equivalente a la $\S 16 \mathrm{~b}$ SEA, establecida en el art. 162-1 de la Ley N 66-537, de 24 de julio de 1966.

211 "Seront punies d'un emprisonnement de deux mois à deux ans et d'une amende de $6000 \mathrm{~F}$ à 5 millions de francs, dont le montant pourra être porté au-delà de ce chiffre jusqu'au quadruple du montant du profit éventuellement réalisé, sans que l'amende ne puisse être inférieure à ce même profit, ou de l'une de ces deux peines seulement, les personnes mentionnées à l'article 162-1 de la loi nº 66-537 du 24 juillet 1966 modifiée sur les sociétés commerciales et les personnes disposant, à l'occasion de l'exercice de leur profession ou de leurs fonctions, d'informations privilégiées sur les perspectives ou la situation d'un émetteur de titres ou sur les perspectives d'évolution d'une valeur mobilière, qui auront réalisé, ou sciemment permis de réaliser, sur le marché boursier, soit directement, soit par personne interposée, une ou plusieurs opérations sur le fondement desdites informations avant que le public en ait connaissance." Disponible en:

http://www.legifrance.gouv.fr/affichTexteArticle.do;jsessionid=B0CB37CA3690207094F5FFAC456AB42A. tpdila10v_3?idArticle=LEGIARTI000006778312\&cidTexte=JORFTEXT000000698676\&categorieLien=id\& dateTexte=19880122 (última consulta: 25.11.2016).

212 "Seront punies d'un emprisonnement de deux mois à deux ans et d'une amende de $6000 \mathrm{~F}$ à 5 millions de francs, dont le montant pourra être porté au-delà de ce chiffre jusqu'au quadruple du montant du profit éventuellement réalisé, sans que l'amende ne puisse être inférieure à ce même profit, ou de l'une de ces deux 
BASCUÑÁN, Antonio. "Posesión, uso y explotación de la información privilegiada como elementos del insider trading en el derecho comparado del mercado de valores".

posteriormente recogida en el CMF, creado por la Ordenanza 2000-1223, de 14 de diciembre de 2000 (publicada el 16 de diciembre de 2000 y con vigencia a partir del $1^{\circ}$ de enero de 2001). El art. L 465-1 inciso primero CMF consagra una norma punitiva del insider trading que tipifica al delito como una acción de quien dispone de información privilegiada consistente en "realizar o permitir realizar, ya sea directamente o por persona interpuesta, una o más operaciones" antes que el público tenga conocimiento de la información $^{213}$. La disposición ha experimentado varias modificaciones desde entonces, pero la estructura básica del delito sigue siendo la misma ${ }^{214}$.

En ejercicio de la competencia otorgada por la Ley 89-531, de 2 de agosto de 1989, la COB estableció el Reglamento 90-08, homologado por el decreto de 17 de julio de 1990. Este reglamento introdujo en el derecho francés la regulación administrativa del insider trading,

peines seulement, les personnes mentionnées à l'article 162-1 de la loi nº 66-537 du 24 juillet 1966 modifiée sur les sociétés commerciales et les personnes disposant, à l'occasion de l'exercice de leur profession ou de leurs fonctions, d'informations privilégiées sur les perspectives ou la situation d'un émetteur de titres ou sur les perspectives d'évolution d'une valeur mobilière ou d'un contrat à terme négociable, qui auront réalisé, ou sciemment permis de réaliser, sur le marché, soit directement, soit par personne interposée, une ou plusieurs opérations avant que le public ait connaissance de ces informations". Disponible en:

http://www.legifrance.gouv.fr/affichTexteArticle.do;jsessionid=B0CB37CA3690207094F5FFAC456AB42A. tpdila10v 3?idArticle=LEGIARTI000006778313\&cidTexte=JORFTEXT000000698676\&categorieLien=id\& dateTexte $=19890803$ (última consulta: 25.11.2016). Esta estructura típica permaneció no obstante las posteriores reformas del art. 10-1 por las Leyes 89-531, de 2 de agosto de 1989 y 92-1336, de 16 de diciembre de 1992, hasta su derogación por la Ley 2003-706, de $1^{\circ}$ de agosto de 2003.

213 "Est puni de deux ans d'emprisonnement et d'une amende de dix millions de francs dont le montant peut être porté au-delà de ce chiffre, jusqu'au décuple du montant du profit éventuellement réalisé, sans que l'amende puisse être inférieure à ce même profit, le fait, pour les dirigeants d'une société mentionnée à l'article L. 225-109 du code de commerce, et pour les personnes disposant, à l'occasion de l'exercice de leur profession ou de leurs fonctions, d'informations privilégiées sur les perspectives ou la situation d'un émetteur dont les titres sont négociés sur un marché réglementé ou sur les perspectives d'évolution d'un instrument financier admis sur un marché réglementé, de réaliser ou de permettre de réaliser, soit directement, soit par personne interposée, une ou plusieurs opérations avant que le public ait connaissance de ces informations." Disponible en:

http://www.legifrance.gouv.fr/affichCodeArticle.do;jsessionid=3CFADEBEE2BC939367E31EA6D4CD5440 .tpdila10v_3?idArticle=LEGIARTI000006654278\&cidTexte=LEGITEXT000006072026\&categorieLien=id \&dateTexte $=20011115$ (última consulta: 25.11.2016).

214 "Est puni de deux ans d'emprisonnement et d'une amende de 1500000 euros dont le montant peut être porté au-delà de ce chiffre, jusqu'au décuple du montant du profit éventuellement réalisé, sans que l'amende puisse être inférieure à ce même profit, le fait, pour les dirigeants d'une société mentionnée à l'article L. 225109 du code de commerce, et pour les personnes disposant, à l'occasion de l'exercice de leur profession ou de leurs fonctions, d'informations privilégiées sur les perspectives ou la situation d'un émetteur ou de ses titres admis aux négociations sur un marché réglementé au sens de l'article L. 421-1 ou pour lesquels une demande d'admission sur un tel marché a été présentée, ou sur un système multilatéral de négociation qui se soumet aux dispositions législatives ou réglementaires visant à protéger les investisseurs contre les opérations d'initiés, les manipulations de cours et la diffusion de fausses informations ou négociés sur un système multilatéral de négociation, admis à la négociation sur un tel marché ou pour lesquels une demande d'admission à la négociation sur un tel marché a été présentée ou sur les perspectives d'évolution d'un instrument financier ou d'un actif visé au II de l'article L. 421-1 admis sur un marché réglementé, de réaliser, de tenter de réaliser ou de permettre de réaliser, soit directement, soit par personne interposée, une ou plusieurs opérations avant que le public ait connaissance de ces informations." Disponible en:

http://www.legifrance.gouv.fr/affichCodeArticle.do;jsessionid=3CFADEBEE2BC939367E31EA6D4CD5440 .tpdila10v_3? idArticle=LEGIARTI000027781630\&cidTexte=LEGITEXT000006072026\&categorieLien=id

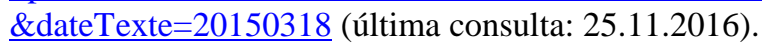


Polít. crim. Vol. 12, No 23 (Julio 2017), Art. 13, pp. 453-532.

[http://www.politicacriminal.cl/Vol_12/n_23/Vol12N23A13.pdf]

configurándolo como una infracción (manquement). El art. $2^{\circ}$ inciso primero de este reglamento formuló la norma como un deber de "abstenerse de explotar" la información por cuenta propia o de otro adquiriendo o vendiendo los títulos ${ }^{215}$. La regulación francesa sobre bancos, instituciones financieras y mercado de capitales fue reformada el año 2003 mediante la Loi de Sécurité Financière, de $1^{\circ}$ de agosto, terminó con la COB y creó la AMF. Un año después, el 24 de noviembre de 2004, la AMF estableció su Reglamento General, que destina su Parte VI al abuso de mercado. Su regulación del insider trading formula la norma de comportamiento como un deber de "abstenerse de utilizar" la información adquiriendo, cediendo o intentando adquirir o ceder los valores ${ }^{216}$.

Así pues, de modo semejante el derecho inglés, el derecho francés consagra un modelo de doble regulación en el que la regulación administrativa establece conforme a su tenor literal una POU mientras que conforme a su tenor literal la regulación penal configura al delito mediante una POP. Pero a diferencia del derecho inglés la legislación francesa no prevé excepciones a una y otra norma, por lo que en el nivel de la regulación expresa del insider trading sigue estándares estrictos de uso y posesión.

La adopción en 1988 por el legislador francés de un estándar de posesión para tipificar el delito de insider trading tuvo el carácter de una recepción legal de un desarrollo jurisprudencial. Bajo la regla de 1970, que sancionaba la operación realizada explotando la información privilegiada, la jurisprudencia francesa afirmó para el insider en posesión de información privilegiada la existencia de un "deber absoluto de abstención" de efectuar operaciones en el mercado de valores ${ }^{217}$. Pero esa jurisprudencia no sostuvo con ello que no hubiera caso alguno en que pudiera ser legítimo para el poseedor de información privilegiada realizar no obstante la operación. Lo que se encontraba en el centro de la

\footnotetext{
215 “Article 2. Les personnes disposant d'une information privilegiée à raison de leur qualité de membres des organes d'administration, de direction, de surveillance d'un émetteur, ou à raison des fonctions qu'elles exercent au sein- d'un tel émetteur doivent s'abstenir d'exploiter, pour compte propre ou pour compte d'autrui, une telle information sur le marche, soit directement, soit par personne interposée, en achetant ou en vendant des titres de cet émetteur, ou des produits financiers liés a ce titre. / Les personnes mentionnées à l'alinéa précédent doivent s'abstenir de communiquer l'information privilégiée à des fins autres ou pour une activite autre que celles à raison desquelles elle est détenue. (...)”. Disponible en:

https://www.google.cl/search?q=Bull.+C.O.B. $+n \% C 2 \% B 0+237 \% 2 C+j u i n+1990) \& o q=B u l l .+C \cdot O \cdot B .+n \% C 2$ $\% \mathrm{~B} 0+237 \% 2 \mathrm{C}+\mathrm{juin}+1990)$ \&aqs $=$ chrome..69i57.656j0j1\&sourceid=chrome\&es $\mathrm{sm}=122 \& \mathrm{ie}=\mathrm{UTF}-$ $8 \# q=$ Bulletin+C.O.B.+n\%C2\%B0+237\%2C+juin+1990 (última consulta: 25.11.2016).

${ }^{216}$ Règlement Général de l'Autorité des Marchés Financiers, art. 622-1: "Toute personne mentionnée à l'article 622-2 doit s'abstenir d'utiliser l'information privilégiée qu'elle détient en acquérant ou en cédant, ou en tentant d'acquérir ou de céder, pour son propre compte ou pour le compte d'autrui, soit directement soit indirectement, les instruments financiers ou les produits de base auxquels se rapporte cette information, au moyen de contrats commerciaux ou d'instruments financiers auxquels ces instruments ou ces contrats commerciaux sont lies". Disponible en:

http://www.amf-france.org/Reglementation/Reglement-general-et-instructions/Reglement-general-envigueur/Reglement-general.html (última visita: 25.11.2016).

${ }^{217}$ IRVING, French Insider Trading, cit. nota 209, pp. 54-57, 65; PETERSEN, "Insider Trading", cit. nota 209, pp. 33-34; UMHOEFER/PIÉTRANCOSTA, "Le Délit d'Initié", cit. nota 209, pp. 121-124; HERNÁNDEZ SAINZ, "La prohibición", cit. nota 209, pp. 803-808. La apreciación que hacen WELCH et al, Comparative Implementation, cit. nota $\mathrm{n}^{\circ} 142$, pp. 45-46, no es matizada: sostienen que el deber absoluto de abstención no admitiría excepciones a la prohibición de efectuar operaciones en posesión de información privilegiada.
} 
BASCUÑÁN, Antonio. "Posesión, uso y explotación de la información privilegiada como elementos del insider trading en el derecho comparado del mercado de valores".

preocupación de los tribunales franceses era la cuestión de la relevancia de las razones o motivos para realizar la operación distintos del razonamiento derivado del conocimiento de la información, como prueba de la ausencia de explotación de la información.

La doctrina francesa del deber absoluto de abstención negó la relevancia de razones o motivos concurrentes, o sea, convirtió la exigencia de explotación en una exigencia de uso al modo en que la doctrina alemana entiende esa diferencia. Pero también fue más allá, pues negó la relevancia de las razones o motivos personales frente a la prohibición de operar en conocimiento de información privilegiada. Una defensa como la garantizada por la § 53-1(c) CJA-1993 (supra, sección 3.5.b) es inaceptable para esta jurisprudencia. La mejor comprensión de la doctrina del deber absoluto de abstención es, pues, atribuirle el carácter de una presunción particularmente robusta de la explotación a partir de la posesión. Lo particular de la doctrina francesa del deber absoluto de abstención es que contrapone motivos privados o de interés personal a motivos públicos o de interés colectivo, o al menos relevantes para el mercado de valores, y entiende las excepciones al deber absoluto de abstención -es decir, los refutadores de la presunción robusta de explotación- como casos de conflicto o colisión de motivos, en que la motivación pública o de interés colectivo debe ser considerada como preponderante. Los ejemplos paradigmáticos opuestos son la solución de un problema de liquidez (interés privado) y la defensa del control de la sociedad frente a un intento de toma de control (interés público, eventualmente). El primer caso no constituye una excepción válida al deber absoluto de abstención, el segundo puede que valga como excepción.

La adopción de un estándar estricto de posesión por la legislación penal en 1988 no alteró sin embargo esta doctrina. Es decir, la jurisprudencia siguió considerando que la concurrencia de motivos públicos preponderantes podía justificar la calificación de la operación en posesión de información como un comportamiento lícito. Aquí se encuentra, probablemente, el origen de la confusión de niveles de referencia a que se hizo mención a propósito del caso Spector (supra, sección 3.3): una presunción es transferida a la formulación del supuesto de hecho de la norma sancionatoria y su refutabilidad es consiguientemente transformada en derrotabilidad de la prohibición correlativa. La diferencia entre la sentencia del caso Spector y la jurisprudencia francesa radica sin embargo en que el ECJ entiende que el fundamento de la derrotabilidad se encuentra en la adecuación del comportamiento con la finalidad de protección de la prohibición, mientras que la doctrina francesa del deber absoluto entiende que ese fundamento se encuentra en la solución correcta a colisión de deberes o intereses.

La diferencia apuntada hace que el estatus de la orden previa como excepción implícita a la prohibición de insider trading sea obvio para el ECJ, pero incierto bajo los términos de la doctrina francesa del deber absoluto de abstención. Pues la orden impartida por el insider cuando no estaba en posesión de información es un acto ciertamente lícito pero su ejecución se encuentra sólo contingentemente (y además, inusualmente) relacionada con la realización de un interés público o colectivo. La exención de la orden previa puede naturalmente justificarse como defensa negativa, si se considera que la conexión entre conocimiento de la información y realización de la operación es un elemento del delito. Y pese a sostener la doctrina del deber absoluto de abstención, la jurisprudencia francesa 
Polít. crim. Vol. 12, No 23 (Julio 2017), Art. 13, pp. 453-532.

[http://www.politicacriminal.cl/Vol_12/n_23/Vol12N23A13.pdf]

parece exigir la concurrencia de ese elemento como propiedad de la información privilegiada. Conforme a la jurisprudencia, la información presupuesta por el art. L 456-1 CMF requiere ser (i) confidencial, (ii) precisa, (iii) naturalmente influyente en el precio del valor, (iv) objetivamente privilegiada y (v) determinante de la operación efectuada. La eliminación en 1988 del requisito legal de que la operación tenga su fundamento en la información no alteró esta jurisprudencia ${ }^{218}$. Esta ambivalencia de la jurisprudencia francesa, que por una parte postula un deber absoluto de abstención y por otra parte exige una relación de causalidad entre el conocimiento de la información y la realización de la operación, sólo puede explicarse entendiendo a la doctrina del deber absoluto de abstención como una regla de presunción de uso a partir de la posesión. Y esa es la única manera de entender que esta ambivalencia perviva incluso bajo una regla legal que prescinde del nexo causal. Tal como lo dice una autora:

"[La modificación legal de 1988] es desafortunada porque ha conducido a algunos a pensar que el legislador ha querido hacer desaparecer el vínculo entre información privilegiada y operación, lo cual sería el colmo del absurdo. De manera consciente y voluntaria, esta sucesiva rebaja [i.e., de 1970 a 1983, y de 1983 a 1988] es únicamente de índole probatoria". ${ }^{219}$

El hecho de que la COB en 1990 y la AMF en 2004 hayan establecido prohibiciones administrativas del insider trading empleando un estándar de uso para definir la infracción es ciertamente compatible con esta idea: esa regulación admite la ambivalencia de la jurisprudencia. No obstante, primero la DAM y ahora en mucho mayor medida el RAM exigen a Francia poner término a la incertidumbre relativa a los casos exceptuados de la prohibición. Dentro de esos casos se encuentra, inequívocamente, la orden previa.

\section{La distinción entre uso y posesión en la regulación española.}

Tal como sucede en el derecho inglés y francés, el derecho español sigue un modelo de doble regulación del insider trading, esto es, lo trata como un ilícito administrativo conforme a la LMV-E y como un delito conforme al CP-E. La redacción de la norma administrativa española responde a grandes rasgos a la DIT y la DAM, pero formula la prohibición como POP. La redacción de la punitiva española no atiende a la regulación administrativa, y tipifica el delito como uso de información privilegiada, requiriendo un resultado de provecho o perjuicio que no exige expresamente la realización de una operación en el mercado de valores. Suponiendo, sin embargo, que se trata de un uso en

218 PONS-HENRY, "Opérations d'inititiés", cit. nota $n^{\circ}$ 209, especialmente p. 213; LASSERRE CAPDEVILLE, "Le délit d'initié", cit. nota n ${ }^{\circ} 209$, especialmente notas 27 y 28 , citando ambos la sentencia de la Corte de Casación de 26 de junio de 1995, $\mathrm{N}^{\circ}$ 93-81.646 (disponible en:

http://www.legifrance.gouv.fr/affichJuriJudi.do?oldAction=rechJuriJudi\&idTexte=JURITEXT000007065963 \&fastReqId=1994173193\&fastPos=1; última consulta: 25.11.2016) y LASSERRE CAPDEVILLE además la sentencia de 14 de junio de 2006, $\mathrm{N}^{\circ}$ 05-82.453 (disponible en:

http://www.legifrance.gouv.fr/affichJuriJudi.do?idTexte=JURITEXT000007074494\&fastReqId=575306395 \&fastPos=6\&oldAction=rechJuriJudi; última consulta: 25.11.2016); HERNÁNDEZ SAINZ cita una sentencia de la Corte de Apelaciones de París de 1977 reconociendo explícitamente la validez de la ejecución de una orden previa (HERNÁNDEZ SAINZ, Esther, El abuso de información privilegiada en los mercados de valores, Madrid: Civitas, 2007, nota 173).

${ }^{219}$ GIUDICELLI-DELAGE, “El delito de iniciados", cit. nota n 209, pp. 404-405. 
BASCUÑÁN, Antonio. "Posesión, uso y explotación de la información privilegiada como elementos del insider trading en el derecho comparado del mercado de valores".

conexión con una operación, se tiene que a la inversa del derecho inglés y francés, la LMVE emplea un estándar de posesión y el CP-E emplea un estándar de uso. Eso es consistente con la idea general de que la prueba del uso permite calificar a la operación como una infracción más grave a la prohibición de insider trading.

\subsection{El ilícito administrativo de insider trading ${ }^{220}$.}

La Ley de Mercado de Valores de España (“LMV-E”), Ley 24/1988, de 28 de julio, dispuso originariamente en su art. 81 inciso primero lo siguiente:

"Art. 81. Quienes dispongan de alguna información privilegiada deberán abstenerse de realizar, directa o indirectamente, cualquier tipo de operación en el mercado sobre los valores a que la misma se refiera. Igualmente se abstendrán de comunicar dicha información a terceros o de recomendar la adquisición o cesión de los valores citados.

A los efectos de la presente Ley se entiende por información privilegiada toda información de carácter concreto, referente a uno o varios valores, que no haya sido dada a conocer al público y que, de haberse hecho pública, hubiera podido influir de modo relevante en su cotización." 221

Conforme a las modificaciones introducidas por la Ley 9/1991, de 22 de marzo, el precepto tuvo la siguiente redacción:

“Art. 81. 1. Todas las personas o entidades que actúen en los mercados de valores o ejerzan actividades relacionadas con ellos y, en general cualquiera que por razón de su trabajo, profesión, cargo o funciones posea datos o informaciones relativos a los mismos, deberán salvaguardar dichos datos e informaciones, sin perjuicio de su deber de comunicación y colaboración con las autoridades judiciales o administrativas en los términos previstos en ésta o en otras leyes. En particular, impedirán que tales datos o informaciones puedan ser objeto de utilización abusiva o desleal, denunciarán los casos en que ello hubiera tenido lugar y tomarán de inmediato las medidas necesarias para prevenir, evitar y, en su caso, corregir las consecuencias que de ello pudieran derivarse.

2. Todo el que disponga de alguna información privilegiada deberá abstenerse de ejecutar, por cuenta propia o ajena, directa o indirectamente, las conductas siguientes:

a) Preparar o realizar cualquier tipo de operación en el mercado sobre los valores a que la información se refiera.

b) Comunicar dicha información a terceros, salvo en ejercicio normal de su trabajo, profesión, cargo o funciones.

c) Recomendar a un tercero que adquiera o ceda valores o que haga que otro los adquiera o ceda, basándose en dicha información.

\footnotetext{
${ }^{220}$ PRAT RODRIGO, Margarita, El uso ilegal de la información privilegiada en las ofertas públicas de adquisición de acciones (EE.UU. 1933-1988). Bilbao: Ediciones Deusto, 1990; GÓMEZ INIESTA, Diego José, La utilización abusiva de información privilegiada en el mercado de valores, Madrid: McGraw Hill, 1997; ENTRENA RUIZ, Daniel, El empleo de información privilegiada en el mercado de valores: Un estudio de su régimen administrativo sancionador. Madrid: Thompson-Civitas, (2006); HERNÁNDEZ SAINZ, Esther, El abuso, cit. nota ${ }^{\circ} 218$.

${ }^{221}$ Ley 24/1988, de 28 de julio, del Mercado de Valores. Texto original publicado el 29/07/1988. Disponible en: http://www.boe.es/buscar/act.php?id=BOE-A-1988-18764\&tn=1\&vd=\&p=19880729 (última consulta: 25.11.2016).
} 
Polít. crim. Vol. 12, № 23 (Julio 2017), Art. 13, pp. 453-532.

[http://www.politicacriminal.cl/Vol_12/n_23/Vol12N23A13.pdf]

3. A los efectos de la presente Ley se entiende por información privilegiada toda información de carácter concreto, que se refiera a uno o varios emisores de valores o a uno o varios valores, que no se haya hecho pública y que, de hacerse o haberse hecho pública, podría o habría podido influir de manera apreciable sobre la cotización de ese o de esos valores.

Esta modificación tuvo por objetivo adecuar la regulación española a la DIT. La comparación de la formulación de la prohibición de insider trading del art. 81 LMV-E en la versión de 1991 con la formulación de la prohibición de insider trading del art. 2-1 DIT permite apreciara que ambas comparten una estructura básica, pero también que existe una diferencia crucial: la regla española prescindió del elemento de explotación deliberada de la información como circunstancia o modo de realización del comportamiento prohibido. Es decir, al menos conforme a su tenor literal la regla española no consagró el ilícito administrativo del insider trading bajo el modelo del uso (explotación) de la información adoptado por la DIT, sino de su posesión ${ }^{222}$.

La redacción del precepto conforme a la Ley 37/1998, de 16 de noviembre, que derogó el número 3 y modificó el número 2, mantuvo esa estructura:

\section{“Artículo 81}

1. Todas las personas o entidades que actúen en los mercados de valores o ejerzan actividades relacionadas con ellos y, en general cualquiera que por razón de su trabajo, profesión, cargo o funciones posea datos o informaciones relativos a los mismos, deberán salvaguardar dichos datos e informaciones, sin perjuicio de su deber de comunicación y colaboración con las autoridades judiciales o administrativas en los términos previstos en ésta o en otras leyes. En particular, impedirán que tales datos o informaciones puedan ser objeto de utilización abusiva o desleal, denunciarán los casos en que ello hubiera tenido lugar y tomarán de inmediato las medidas necesarias para prevenir, evitar y, en su caso, corregir las consecuencias que de ello pudieran derivarse.

2. Se considerará información privilegiada toda información de carácter concreto que se refiera a uno o varios valores y a uno o varios emisores de valores, que no se haya hecho pública y que, de hacerse o haberse hecho pública, podría influir o hubiera influido de manera apreciable sobre la cotización de tales valores.

Todo el que disponga de alguna información privilegiada deberá abstenerse de ejecutar por cuenta propia o ajena, directa o indirectamente, alguna de las conductas siguientes:

a) Preparar o realizar cualquier tipo de operación en el mercado sobre los valores a los que la información se refiere.

b) Comunicar dicha información a terceros, salvo en el ejercicio normal de su trabajo, profesión o cargo.

\footnotetext{
${ }^{222}$ Las razones del legislador español para haber adoptado este modelo no son evidentes. Quizás haya pesado la formulación del insider trading en contextos de OPAs contenida en el art. 12 inciso segundo del Real Decreto 1.848/1980, de 5 de septiembre, posteriormente sustituido por el Real Decreto 279/1984, de 25 de enero. Conforme a ese precepto: "Los miembros de los Consejos de Administración y los directores de la sociedad promotora o afectada, o cualquier persona en situación de conocer la información confidencial correspondiente a la fase preparatoria de una oferta, además de guardar el secreto de las negociaciones deberán abstenerse de hacer operación alguna en condiciones diferentes a las de la propia oferta pública de adquisición." Citado según su transcripción en PRAT RODRIGO, El uso ilegal, cit. nota n 220, p. 170 y 179.
} 
BASCUÑÁN, Antonio. "Posesión, uso y explotación de la información privilegiada como elementos del insider trading en el derecho comparado del mercado de valores”.

c) Recomendar a un tercero que adquiera o ceda valores o que haga que otro los adquiera o ceda basándose en dicha información.

Por último, en la redacción dada por las modificaciones introducidas por el art. 38-tercero de la Ley 44/2002, de 23 de noviembre, de Medidas de Reforma del Sistema Financiero, los dos primeros apartados del art. 81 LMV-E pasaron a ser del siguiente tenor:

"Artículo 81.

1. Se considerará información privilegiada toda información de carácter concreto que se refiera directa o indirectamente a uno o varios valores negociables o instrumentos financieros de los comprendidos dentro del ámbito de aplicación de esta Ley, o a uno o varios emisores de los citados valores negociables o instrumentos financieros, que no se haya hecho pública y que, de hacerse o haberse hecho pública, podría influir o hubiera influido de manera apreciable sobre su cotización en un mercado o sistema organizado de contratación. Lo dispuesto en el párrafo anterior será de aplicación también a los valores negociables o instrumentos financieros respecto de los cuales se haya cursado una solicitud de admisión a negociación en un mercado o sistema organizado de contratación. En relación con los instrumentos financieros derivados sobre materias primas se considerará información privilegiada toda información de carácter concreto, que no se haya hecho pública, y que se refiera directa o indirectamente a uno o a varios de esos instrumentos financieros derivados, que los usuarios de los mercados en que se negocien esos productos esperarían recibir con arreglo a las prácticas de mercado aceptadas en dichos mercados.

2. Todo el que disponga de información privilegiada deberá abstenerse de ejecutar por cuenta propia o ajena, directa o indirectamente, alguna de las conductas siguientes:

a) Preparar o realizar cualquier tipo de operación sobre los valores negociables o sobre instrumentos financieros de los mencionados en el apartado anterior a los que la información se refiera, o sobre cualquier otro valor, instrumento financiero o contrato de cualquier tipo, negociado o no en un mercado secundario, que tenga como subyacente a los valores negociables o instrumentos financieros a los que la información se refiera.

Se exceptúa la preparación y realización de las operaciones cuya existencia constituye, en sí misma, la información privilegiada, así como las operaciones que se realicen en cumplimiento de una obligación, ya vencida, de adquirir o ceder valores negociables o instrumentos financieros, cuando esta obligación esté contemplada en un acuerdo celebrado antes de que la persona de que se trate esté en posesión de la información privilegiada, $\mathrm{u}$ otras operaciones efectuadas de conformidad con la normativa aplicable.

b) Comunicar dicha información a terceros, salvo en el ejercicio normal de su trabajo, profesión o cargo.

c) Recomendar a un tercero que adquiera o ceda valores negociables o instrumentos financieros o que haga que otro los adquiera o ceda basándose en dicha información.

Las prohibiciones establecidas en este apartado se aplican a cualquier persona que posea información privilegiada cuando dicha persona sepa, o hubiera debido saber, que se trata de esta clase de información. (...)"223

\footnotetext{
${ }^{223}$ Ley $24 / 1988$, de 28 de julio, del Mercado de Valores. Texto consolidado. Última actualización publicada el 05/03/2011. Disponible en:

http://www.boe.es/buscar/act.php?id=BOE-A-1988-18764\&tn=1\&vd=\&p=20141204 (última consulta: 25.11.2016).
} 
Polít. crim. Vol. 12, № 23 (Julio 2017), Art. 13, pp. 453-532.

[http://www.politicacriminal.cl/Vol_12/n_23/Vol12N23A13.pdf]

En términos generales, las modificaciones introducidas por la Ley 44/2002 en el art. 81 LMV-E se explican como una recepción anticipada de la DAM. Eso es particularmente evidente en la ampliación que experimenta el concepto de información privilegiada y sobre todo en el inciso segundo del art. 81-2(a), que parcialmente reproduce la regla del art. 2-3 DAM. No obstante, a pesar de orientarse una vez más al modelo ofrecido por el derecho común europeo, la Ley 44/2002 mantuvo la formulación tradicional española de la prohibición de insider trading, prescindiendo de la exigencia expresa de uso de la información poseída en la descripción del ilícito administrativo.

Como se puede apreciar, la regulación administrativa española representa un caso de pervivencia tenaz de formulación de la prohibición de insider trading como POP en un contexto cultural dominado por el estándar de uso, tanto en su versión más drástica (el art. 2-1 DIT) como en una versión más moderada (Art. 2-1 DAM). No obstante, es importante tener presente que en la fase posterior de su evolución la regulación explícitamente deja el estándar estricto de posesión para consagrar el estándar modificado de posesión.

\subsection{El delito de insider trading ${ }^{224}$.}

A diferencia de la LMV-E el Código Penal español siempre ha tipificado el delito de insider trading mediante la fórmula del uso de información privilegiada. Los trabajos preparatorios del CP-E de 1995 incluso describían la acción como realizar una operación "prevaliéndose de una información privilegiada" (Anteproyecto de Código Penal de 1992, art. $298 \mathrm{~N}^{\circ}$ 1) o derechamente como "abusar de alguna información confidencial" (Anteproyecto de 1994, art. $\left.281 \mathrm{~N}^{\circ} 1\right)^{225}$.

En su formulación originaria de 1995, el art. 285 CP-E era del siguiente tenor:

"Artículo 285. Quien de forma directa o por persona interpuesta usare de alguna información relevante para la cotización de cualquier clase de valores o instrumentos negociados en algún mercado organizado, oficial o reconocido, a la que haya tenido acceso reservado con ocasión del ejercicio de su actividad profesional o empresarial, o la suministrare obteniendo para sí o para un tercero un beneficio económico superior a setenta y cinco millones de pesetas o causando un perjuicio de idéntica cantidad, será castigado con la pena de prisión de uno a cuatro años y multa de tanto al triplo del beneficio obtenido o favorecido."226

\footnotetext{
${ }^{224}$ MARTÍNEZ-BUJÁN PÉREZ, Carlos, “Comentario al art. 285”, en: VIVES ANTÓN, Tomás S. (coord.), Comentarios al Código Penal de 1995. Valencia: Tirant lo Blanch. Volumen 2, 1996, pp. 1382-1392; HERNÁNDEZ SAINZ, Esther, "La regulación penal de los abusos de información privilegiada", Actualidad Penal n 9, (1997), 173-216; GÓMEZ INIESTA, Utilización abusiva, cit. nota $\mathrm{n}^{\circ}$ 220; PRIETO DEL PINO, Ana María, El derecho penal ante el uso de información privilegiada en el mercado de valores. Cizur Menor (Navarra): Thompson-Aranzadi, 2004; MARTÍNEZ-BUJÁN PÉREZ, Carlos, Derecho Penal Económico y de la Empresa. Parte Especial. Valencia: Tirant lo Blanc (2 ed.), 2005; VEGA GUTIÉRREZ, José Zamyr, Mercado de Valores en Derecho Penal. Montevideo: B de f, 2013.

${ }^{225}$ GÓMEZ INIESTA, Utilización abusiva, cit. nota n² 220, pp. 358-363.

${ }^{226}$ Ley Orgánica 10/1995, de 23 de noviembre, del Código Penal. Texto original publicado el 24/11/1995. Disponible en: http://www.boe.es/buscar/act.php?id=BOE-A-1995-25444\&tn=1\&vd=\&p=19951124 (última consulta: 25.11.2016).
} 
BASCUÑÁN, Antonio. "Posesión, uso y explotación de la información privilegiada como elementos del insider trading en el derecho comparado del mercado de valores".

En su redacción posterior, introducida por la LO 15/2003, de 25 de noviembre, el precepto es del siguiente tenor:

"Artículo 285. 1. Quien de forma directa o por persona interpuesta usare de alguna información relevante para la cotización de cualquier clase de valores o instrumentos negociados en algún mercado organizado, oficial o reconocido, a la que haya tenido acceso reservado con ocasión del ejercicio de su actividad profesional o empresarial, o la suministrare obteniendo para sí o para un tercero un beneficio económico superior a 600.000 euros o causando un perjuicio de idéntica cantidad, será castigado con la pena de prisión de uno a cuatro años, multa del tanto al triplo del beneficio obtenido o favorecido e inhabilitación especial para el ejercicio de la profesión o actividad de dos a cinco años.

2. Se aplicará la pena de prisión de cuatro a seis años, la multa del tanto al triplo del beneficio obtenido o favorecido e inhabilitación especial para el ejercicio de la profesión o actividad de dos a cinco años, cuando en las conductas descritas en el apartado anterior concurra alguna de las siguientes circunstancias:

$1 .^{\text {a }}$ Que los sujetos se dediquen de forma habitual a tales prácticas abusivas.

2. ${ }^{a}$ Que el beneficio obtenido sea de notoria importancia.

3. ${ }^{a}$ Que se cause grave daño a los intereses generales." ${ }^{227}$

Como salta a la vista, la estructura típica del delito de insider trading, tal como es configurada por el art. $285 \mathrm{CP}-\mathrm{E}$, es equivalente a la descripción de la acción prohibida bajo el $\S 14 \mathrm{WpHG}$ en su versión vigente a partir del año 2004, si se supone que el uso se concreta en una operación en el mercado de valores. No es de extrañar por lo tanto la amplia recepción de la doctrina alemana en la obra más reciente y completa de la doctrina española ${ }^{228}$.

\subsection{El estatus de la orden previa.}

El tratamiento del estatus de la orden previa por la doctrina española se ha visto parcialmente oscurecido por su tematización a propósito del tratamiento del insider non trading, es decir, los casos en que el conocimiento de la información induce al insider a no realizar una operación que tenía proyectada. Esta tematización se ha visto a su vez oscurecida por la consideración del insider non trading como una eventual comisión por omisión del delito de uso de información privilegiada. ${ }^{22}$ Ambas asociaciones incurren en una confusión que conviene aclarar.

${ }^{227}$ Ley Orgánica 10/1995, de 23 de noviembre, del Código Penal. Texto consolidad. Última actualización publicada el 28/04/2015. Disponible en:

http://www.boe.es/buscar/act.php?id=BOE-A-1995-25444\&tn=1\&vd=\&p=20150428 ｕ́ltima consulta: 25.11.2016).

${ }^{228}$ VEGA GUTIÉRREZ, Mercado de Valores cit. nota n ${ }^{\circ} 224$, pp. 282 y ss.

${ }^{229}$ Esta asociación confusa proviene de una comprensión equivocada que hace HERNÁNDEZ SAINZ, "La regulación penal", cit, nota $\mathrm{n}^{\circ} 224$, p. 193 y El abuso, cit. nota $\mathrm{n}^{\circ} 218$, pp. 540 ss., de un planteamiento originario de MARTÍNEZ-BUJÁN PÉREZ, "Comentario", cit, nota n ${ }^{\circ} 224$, pp. 1387-1390. Este autor identificaba dos casos de insider non trading: (a) el autor de una orden que decide cancelarla, pero que luego se desiste al conocer información privilegiada; (b) el que habiendo pensando en realizar una operación se desiste al conocer información privilegiada. La autora mencionada entiende la primera hipótesis simplemente como el caso de la orden previa: se imparte una orden sin conocimiento de información privilegiada y no se la cancela cuando se entra en conocimiento de una información privilegiada que confirma su racionalidad. Pero 
Polít. crim. Vol. 12, No 23 (Julio 2017), Art. 13, pp. 453-532.

[http://www.politicacriminal.cl/Vol_12/n_23/Vol12N23A13.pdf]

En primer lugar, la cuestión de la relevancia jurídica de la comisión por omisión del delito de uso de información privilegiada o del ilícito administrativo de la operación en posesión de información privilegiada no se refiere a la omisión de efectuar una operación, sino a la tolerancia u omisión de evitación de la realización de la operación por otra persona. Esa es una cuestión que en el contexto del derecho europeo examinado sólo es resuelta afirmativamente de modo explícito por el derecho penal francés: en tanto el art. L 465-1 CMF no sólo sanciona a quien realiza sino también a quien "permite realizar"230 la operación en posesión de información privilegiada, equipara la omisión de evitación de la comisión del delito por otro a su comisión. Ausente una regla semejante, la cuestión queda entregada a la aplicabilidad de las reglas generales del sistema jurídico relativas a la punición de la comisión por omisión, tanto en la pregunta por la afirmación del deber de garante como en su extensión a la evitación de acciones de terceros en lugar de evitación de resultados $^{231}$.

En segundo término, la cuestión de la relevancia del insider non trading y la cuestión de la diferencia o semejanza de la cancelación de una orden previa a la mera abstención de operar requiere ser resuelta en dos planos. El primero es el de la legalidad. Suponiendo que la prohibición de insider trading se encuentra sujeta a una prohibición de generalización de su alcance más allá del sentido literal posible (nullum crimen nula poena sine lege stricta) es necesario constatar si la regla exige o no como elemento de la infracción o delito la realización de una operación consistente en una transacción en el mercado de valores. Si la exige, es una prohibición de uso operativo de la información privilegiada; si no lo exige, es una prohibición general de uso o de uso no especificado de información privilegiada ${ }^{232}$. El establecimiento de una prohibición de uso operativo de información privilegiada es el caso del derecho federal estadounidense, que requiere que el fraude se cometa en conexión con una compra o venta de valores ${ }^{233}$, y también del derecho alemán, cuyo $§ 14$ WpHG declara prohibido "adquirir o enajenar" valores ${ }^{234}$. Esta exigencia legal hace que la abstención de operar en el mercado de valores, incluyendo la abstención que corresponde a la cancelación de una orden previa, no pueda ser calificada como insider trading prohibido, cualquiera sea el mérito que quepa atribuirle desde una perspectiva de análisis económico o político-

conforme a la construcción de MARTÍNEZ-BUJÁN PÉREZ ese no es un caso de insider non trading, sino un caso de operación en posesión de información privilegiada. PRIETO DEL PINO también comprende equivocadamente la hipótesis (a), como el caso de una orden impartida antes de conocer información pero cuya ejecución está sujeta a ratificación y que no es revocada con posterioridad al conocimiento de la información (PRIETO DEL PINO, El derecho penal, cit. nota $n^{\circ} 224$, p. 374). Este es un caso de operación en uso de información privilegiada, como bien lo observa esta autora (op. cit., p. 376). Producto de las dos equivocaciones, HERNÁNDEZ SAINZ llega a la conclusión -equivocada- de que Prieto del Pino consideraría al caso de la orden previa como una operación en uso de información privilegiada (El abuso, cit. nota $\mathrm{n}^{\circ} 218$, p. 540 nota 169$)$.

${ }^{230}$ Supra, notas $\mathrm{n}^{\circ}$ 212, 213. La formulación del supuesto de hecho incluyendo la hipótesis de "permitir realizar" proviene de la reforma legal de 1983 (supra, nota $\mathrm{n}^{\circ} 211$ ), aunque en ese entonces estuviera subjetivamente restringida a quien permite "a sabiendas" ( "sciemment").

231 SETHE, "Insiderrecht”, cit. nota n 34, nm. 81 ss.; VEGA GUTIÉRREZ, Mercado de Valores cit. nota $n^{\circ}$ 224, pp. 315 ss.; GÓMEZ INIESTA, Utilización abusiva, cit. nota n ${ }^{\circ} 220$, pp. 353, 416 y ss.

${ }^{232}$ Obviamente, no existe una alternativa equivalente para la POP, porque no tiene sentido una prohibición no especificada de acciones en posesión de información privilegiada.

${ }^{233}$ Supra, sección 3.5.a.

${ }^{234}$ Supra, nota 145. 
BASCUÑÁN, Antonio. "Posesión, uso y explotación de la información privilegiada como elementos del insider trading en el derecho comparado del mercado de valores".

jurídica. El derecho penal español no presenta una restricción semejante. El art. 285 CP-E hace punible la acción de "usar información" obteniendo un beneficio o causando un perjuicio, es decir, establece una prohibición de uso no especificado. En cuanto al derecho administrativo español, el art. 81-2-(a) LMV-E establece el deber de abstenerse de realizar "cualquier operación" estando en posesión de información privilegiada, lo que puede ser interpretado restrictivamente (enfatizando la exigencia de una transacción en el mercado de valores) o extensivamente (enfatizando la apertura del adjetivo "cualquiera"). La ausencia de una restricción legal para la calificación de la abstención de operar en el mercado de valores plantea la pregunta por su estatus bajo la prohibición del insider trading.

La única respuesta explícita a esta pregunta en el derecho comparado examinado se encuentra en el art. 8-1 RAM. Como se ha visto (supra, sección 3.4), esa regla por una parte exige que el insider trading consista en realizar una operación "adquiriendo, transmitiendo o cediendo" instrumentos financieros y por otra parte establece expresamente que la cancelación o modificación de una orden previa se considerará como operación. Es decir, la regla hace una diferencia entre la mera abstención de operar y la abstención que es consecuencia de la cancelación o modificación de una orden. Como se dijo en la introducción a este artículo ese es el tratamiento correcto desde el punto de vista del análisis económico que corresponde al fundamento de la prohibición como medida de protección de (la confianza en) la integridad del mercado de valores.

La doctrina española coincide en la irrelevancia jurídica, tanto administrativa como penal, de la decisión pura y simple de abstenerse de realizar una operación. Las razones usualmente esgrimidas son el hecho de que el derecho del mercado de valores no impone un deber de realizar operaciones proyectadas ${ }^{235}$ y el hecho de que la abstención no tiene incidencia en la cotización del instrumento en el mercado de valores ${ }^{236}$. En cuanto a la orden previa, es decir, el caso de una orden impartida con anterioridad a la posesión de información privilegiada que es dejada ejecutar con posterioridad a la posesión de información privilegiada, la doctrina española tiene apreciaciones diferenciadas.

La postura más radical es la defendida por la principal monografía relativa a la infracción administrativa de insider trading, la obra de Esther Hernández Sáinz ${ }^{237}$. Esta autora considera al caso de la orden previa como insider non trading, es decir, como abstención de operar en el mercado de valores y en tal razón afirma su plena licitud. En sus palabras:

"No hay una identidad estructural entre la no cancelación de una orden que se ha dado y la realización de una compra o venta con información privilegiada, por una razón elemental: el primer supuesto no entraña peligro alguno para el bien jurídico, ya que la posición que se ostenta en el mercado fue adquirida cuando aún no se poseía información privilegiada y por lo tanto sin que mediase un aprovechamiento de las ineficiencias intrínsecas del mercado. ${ }^{238}$

${ }^{235}$ MARTÍNEZ-BUJÁN PÉREZ, “Comentario”, cit. nota n 224, p. 1388; MARTÍNEZ-BUJÁN PÉREZ, Derecho Penal, cit. nota ${ }^{\circ} 224$, p. 301.

${ }^{236}$ PRIETO DEL PINO, El derecho penal, cit. nota n ${ }^{\circ} 224$, p. 377;

${ }^{237}$ HERNÁNDEZ SAINZ, El abuso, cit. nota n ${ }^{\circ} 218$, pp. 540-544. La postura ya había sido anticipada en HERNÁNDEZ SAINZ, "La regulación penal", cit. nota n 224, pp. 193-194.

${ }^{238}$ HERNÁNDEZ SAINZ, El abuso, cit. nota n 218, p. 542. 
Polít. crim. Vol. 12, № 23 (Julio 2017), Art. 13, pp. 453-532.

[http://www.politicacriminal.cl/Vol_12/n_23/Vol12N23A13.pdf]

\section{$(\ldots)$}

El art. 81 LMV (...) en ningún caso impone obligaciones de hacer o actuar de forma activa. Por lo tanto, la no intervención en el mercado no es estructuralmente equivalente a la obligación de llevar a cabo una acción positiva. La interpretación contraria a la aquí sostenida supondría imponer al sujeto el deber de actuar para remover los efectos de una situación (su ventaja en el mercado) que ha surgido en forma ilícita. Se estaría imponiendo una obligación de autoinflingirse (sic) un daño económico cuando se conozca una información privilegiada. Las exigencias de comportamiento leal en el mercado conforme a la buena fe no exigen ese sacrificio."239

A partir de esta tesis, la autora sostiene que la orden previa tiene el mismo estatus que la abstención pura y simple de operar: son omisiones no alcanzadas por el deber de abstención del art. 81-2-(a) LMV-E ${ }^{240}$. Esto diferenciaría, según ella, la posición del que imparte la orden y posteriormente entra en posesión de información privilegiada, del que recibe la orden y la ejecuta en posesión de información privilegiada. Este último, si bien al ejecutar la orden no usa la información que posee, realiza una operación en posesión de información y por lo tanto se encuentra prima facie alcanzado por el deber de abstención del art. 81-2(a) LMV-E. A su respecto, el art. 81-2-(a) inciso segundo LMV opera como causa de justificación $^{241}$. Aquel en cambio, no realiza una operación en posesión de información privilegiada.

En los resultados, este artículo coincide con la tesis de esta autora. También coincide con su premisa desde un punto de vista del análisis económico y la consideración de la funcionalidad al orden del mercado de valores, como ya se expuso en la introducción. Sin embargo, no parece posible sostener que el caso de la orden previa sea un supuesto de insider non trading. Ello, por la sencilla razón de que la orden lícitamente impartida no es una "posición que se ostenta en el mercado" estructuralmente equivalente a la propiedad sobre valores ya adquiridos lícitamente. Esa posición se alcanza con la ejecución de la orden y al momento de ejecutársela quien impartió la orden se encuentra en posesión de información privilegiada. La autora no comparte esta apreciación porque considera que el momento de consumación de la infracción corresponde al momento en que se imparte orden, siendo irrelevante el curso de acción posterior ${ }^{242}$. Pero si entiende que la operación

${ }^{239}$ Op. cit. p. 542-453.

240 Op. cit. p. 544.

${ }^{241}$ Op. cit. p. 548-549. Según la autora, en el contexto del art. 2-3 DAM la exención no es más que la explicitación de la ausencia de uso de la información poseía por el que ejecuta una orden para él vinculante. Pero dado que la LMV-E prohíbe la operación en posesión de información, la exención no puede operar como explicitación de su alcance sino como autorización excepcional, esto es, como causa de justificación.

${ }^{242} \mathrm{La}$ autora sostiene que la infracción se encontraría consumada porque al momento de dar la orden "el sujeto ya ha hecho todo lo que de él dependía para violar la norma" (HERNÁNDEZ SAINZ, El abuso, cit. nota $n^{\circ} 218$, p. 538). Eso demuestra su error: ella confunde la consumación con el acabamiento de la tentativa. Es cierto que tratándose del autor de propia mano de una infracción de merca actividad no podría haber acabamiento de tentativa sin consumación (la autora lo expresa de modo equivocado, al decir que no podría haber tentativa de ninguna clase: op. cit. p. 538 nota 162). Pero basta con que se trate de un inductor o autor mediato, como es quien imparte la orden respecto del ejecutor, para que surja la posibilidad de una tentativa acabada del "hombre de atrás" de la operación. Cabe señalar que la autora planteó originalmente esta tesis en el contexto de su análisis del art. 285 CP-E, donde la acción típica consiste en "usar de alguna información"; en ese contexto, dependiendo de la concepción que se tenga del resultado de beneficio o perjuicio, la orden misma puede ser considerada como una acción típica que realiza el delito en grado de consumación. Pero eso 
BASCUÑÁN, Antonio. "Posesión, uso y explotación de la información privilegiada como elementos del insider trading en el derecho comparado del mercado de valores".

prohibida es la transacción en el mercado de valores, entonces salta a la vista la improcedencia de llegar al resultado que ella defiende mediante la tesis que ella propone. Si el ejecutor que entró en conocimiento de información privilegiada con posterioridad a haber recibido una orden realiza directamente y por cuenta de otro una operación en posesión de información privilegiada cuando ejecuta esa orden -eso lo reconoce la autora-, entonces no puede negarse que el autor de la orden que entró en conocimiento de información privilegiada con posterioridad a haberla impartido realiza indirectamente y por cuenta propia una operación en posesión de información privilegiada cuando ella es ejecutada. Se puede compartir todo el razonamiento que, bajo ciertas condiciones, equipara la valoración económica de la omisión de evitación de una operación con la omisión de una operación; se puede asimismo concluir que esa equiparación debe traducirse en un tratamiento jurídico equivalente. Pero desde el punto de vista de la descripción de la acción para su subsunción en el supuesto de hecho de una norma sancionatoria o en el frástico de una norma de comportamiento, la omisión de evitación de una operación es un hecho simétricamente opuesto a la omisión de una operación: en este último caso no hay transacción, en aquél sí. Por eso es que se genera el problema del estatus de la orden previa: es operación en posesión de información privilegiada que manifiestamente no constituye operación en uso de esa información ${ }^{243}$.

En oposición a Esther Hernández, Ana María Prieto del Pino considera que el caso de la orden previa debe ser distinguido del caso de insider non trading, que éste consiste exclusivamente en situaciones en que no se opera con los instrumentos financieros y que el tratamiento de estas situaciones no debe hacerse bajo la categoría de la comisión por omisión, porque no se trata de un deber de protección del bien jurídico respecto de peligros creados por fuentes ajenas al ámbito de organización del destinatario de ese deber ${ }^{244}$. En lo que respecta a la abstención de operar, esta autora considera que su licitud se fundamenta en el hecho de que quien se limita a mantener su cartera accionarial no incide en la formación de la cotización de esos valores ${ }^{245}$. En lo que respecta, por último, a la orden

no se debe a que el autor haya puesto de su parte todo lo que de él dependía para violar la norma, sino de la descripción que la norma hace de la acción prohibida, que no requiere la realización de una operación en el mercado de valores. Por esta razón, el análisis no es transferible al art. 81-2-(a) LMVE-E.

${ }^{243}$ HERNÁNDEZ SAINZ afirma que su tesis tiene sustento en la jurisprudencia y la doctrina francesas ( $E l$ abuso, cit. nota $\mathrm{n}^{\circ} 218$, p. 538 nota 163). Esas fuentes más bien parecieran sostener la tesis de que para efectos de determinar la incidencia causal de la información en la operación debe atenderse al momento en que se imparte la orden, lo que es obviamente correcto. Cuando la norma de comportamiento consiste en una POU, la operación tiene la estructura de un mandato y la orden del mandante es la sola razón de la operación del mandatario, es obvio que debe atenderse exclusivamente al momento en que el mandante imparte la orden: una posesión posterior a la orden no puede ser usada en la operación. Distinto es el caso cuando la norma de comportamiento consiste en una POP: la operación posterior a la orden es operación indirecta del poseedor de información privilegiada. Por esta razón, la tesis de la autora es inconsistente con toda la discusión y regulación de la exención de la orden previa en el derecho federal estadounidense, inglés, alemán y común europeo.

${ }_{244}^{4}$ PRIETO DEL PINO, El derecho penal, cit. nota ${ }^{\circ} 224$, p. 374.

${ }^{245}$ Op. cit. p. 377. De esta tesis la autora deduce que la cancelación de una orden previa, basada en el conocimiento posterior de información, debe tener el mismo tratamiento (ibídem). Cabe señalar que el fundamento de esta conclusión no se encuentra en la configuración del supuesto de hecho de la norma administrativa o penal española, sino en la falta de relevancia del comportamiento para el bien jurídico. Esta tesis, hoy en día insostenible de cara al art. 8-1 RAM, es en verdad curiosa: la autora señala que el problema práctico más importante es la emisión de órdenes especulativas antes de poseer información y su posterior 
Polít. crim. Vol. 12, No 23 (Julio 2017), Art. 13, pp. 453-532.

[http://www.politicacriminal.cl/Vol_12/n_23/Vol12N23A13.pdf]

previa, Prieto del Pino, distingue entre el caso en que la orden haya sido impartida incondicionalmente y sea ejecutada sin intervención ulterior de quien la impartió, aunque al momento de su ejecución posea información privilegiada, y el caso en que la orden haya sido impartida condicionalmente y sea ejecutada en virtud de su confirmación con conocimiento de información privilegiada. Este segundo caso constituye uso activo de información privilegiada ${ }^{246}$. En el primer caso, en cambio, la información no incide en sobre la operación y por tal razón no hay uso de la misma. En sus palabras:

"Debe descartarse la existencia de uso de información privilegiada en todos aquellos casos en los que el sujeto accede a la misma tras haber emitido la orden siempre y cuando la ejecución de la misma no se haga depender de una posterior confirmación. En efecto, si la compra o la venta son consecuencia directa de una orden cuyo proceso de elaboración ha sido ajeno por completo al influjo de la información, no cabe más que afirmar su ilicitud." 247

La tesis debe entenderse contextualmente referida al art. $285 \mathrm{CP}-\mathrm{E}$, esto es, a la norma punitiva del insider trading concebido como operación en uso de la información privilegiada. Respecto de la licitud o ilicitud de la operación que corresponde a una orden previa bajo el art. 81-2-(a) LMV-E no hay un pronunciamiento definido en esta autora.

Finalmente, en la última monografía extensa sobre el delito español de insider trading José Zamyr Vega Gutiérrez sostiene que la regla del art. 81-2-(a) inciso segundo LMV-E, tomada como se ha visto del art. 2-3 DAM (supra, sección 5.1) contempla implícitamente la exigencia de una causalidad psíquica entre el conocimiento de la información privilegiada y la realización de la operación, al declarar inaplicable la prohibición a la operación cuya ejecución cumple con una obligación contemplada en un acuerdo celebrado antes de que la persona de que se trate esté en posesión de información privilegiada ${ }^{248}$. Respecto de la prohibición de uso de la información consagrada en el art. 285 Vega Gutiérrez va más lejos, sosteniendo que "quedan excluidas del tipo aquellas operaciones que ya estuvieran previstas con anterioridad al conocimiento de la información reservada, pues -en tales casos- no existe la relación de causalidad aludida". ${ }^{249}$ A la luz de la distinción entre explotación y uso, y de la evolución del derecho europeo bajo esa distinción, esta es una concesión excesiva a la subjetividad del insider. No cabe duda, sin embargo, que el caso de la orden previa excluye la incidencia de la información en la operación.

\section{Conclusiones.}

El examen de derecho comparado efectuado -la legislación federal estadounidense, el derecho común europeo, el derecho alemán, español, francés, inglés, italiano y suizo entre

cancelación si el conocimiento de la información desaconseja su ejecución (op. cit. p. 375). Si eso es problemático para el mercado de valores, la cancelación de la orden no puede ser valorada como un comportamiento irrelevante para el orden del mercado de valores.

${ }^{246}$ Op. cit. p. 376.

${ }^{247}$ Op. cit. p. 375.

${ }^{248}$ VEGA GUTIÉRREZ, Mercado de Valores cit. nota n 224, pp. 291-292.

${ }^{249}$ Op. cit. p. 291. 
BASCUÑÁN, Antonio. "Posesión, uso y explotación de la información privilegiada como elementos del insider trading en el derecho comparado del mercado de valores".

1970 y 2014 - demuestra que la prohibición de operar con información privilegiada (PO) recibe dos formulaciones alternativas: a veces es formulada como prohibición de operar en posesión de información privilegiada (POP) -así la R14e-3 SEC, la § 52 CJA-1993, el art. L 465-1 CMF, el art. 81-2(a) LMV-E- y a veces es formulada como prohibición de operar en uso de información privilegiada (POU) -así, los arts. 184 y 187 TUF, el art. 118(2)(a) FSMA, el $§ 14 \mathrm{WpHG}$, el art. 622-1 RGAMF y el at. 285 CP-E-.

La formulación de la PO como POU exige como elemento del delito o infracción que la información poseída haya influido en la operación como razón o motivo de la decisión de operar. Por esta razón, frente a una imputación por infracción de una POU es posible hacer valer una defensa negativa, esto es, negar la realización del supuesto de hecho por falta de concurrencia de un elemento integrante del delito o infracción, cuando la operación ha sido realizada por una razón suficiente distinta de la posesión de información privilegiada. Cuando la operación basada en esa razón es consistente con la protección de la (confianza en la) integridad del mercado de valores, es decir, cuando realizar la operación no implica efectuar una transacción con aprovechamiento de una ventaja indebida respecto de los demás inversionistas, su licitud no es problemática. Ese es el caso de la operación indirectamente realizada cuando se ejecuta una orden que impartida con anterioridad a la posesión de información privilegiada, aunque quien la impartió posea información cuando la orden es ejecutada. La orden es la razón suficiente de la operación y ella no se basó en información privilegiada.

La formulación de la PO como POU puede volverse sin embargo problemática para la protección de la (confianza en la) integridad del mercado de valores en la medida en que se atribuya al uso de la información poseída el carácter de condición necesaria (sine qua non) de la operación. En esa medida, cualquier prueba de la existencia de una razón o motivo para realizar la operación adicional a la información poseída, y de peso $\mathrm{n}$ la decisión de operar, puede en principio valer como excepción negativa frente al cargo de infracción de la POU, a pesar de que el conocimiento de la información -y con ello, la ventaja indebidahaya desempeñado un rol como razón o motivo de la decisión de operar. Esta concepción restrictiva del alcance de la POU es conocida en el derecho comparado como formulación de la PO bajo un estándar de "explotación" de la información privilegiada, que es característico del derecho suizo . El derecho comparado no favorece esa formulación, sino más bien la que corresponde a una comprensión extensiva del alcance de la POU, que abarca casos en que el conocimiento de la información es razón o motivo concomitante de la decisión de operar junto a otras razones o motivos. Eso reduce el alcance de la excepción negativa admisible. Esta comprensión es característica del derecho alemán desde 2004, fecha en la cual sustituyó el estándar de explotación por el de simple uso.

La formulación de la PO como POP tiene por finalidad evitar la ambigüedad del uso como elemento del delito o la infracción. Eso la hace una norma de comportamiento mucho más operativa judicialmente para las agencias estatales encargadas de la aplicación de sanciones al insider trading. El problema de la POP como formulación de la norma de comportamiento es que resulta sobreinclusiva, pues conforme a su tenor literal alcanza también los casos en que la posesión de la información no tuvo influencia alguna en la operación. El modo como el derecho comparado resuelve esta dificultad es reconociendo 
Polít. crim. Vol. 12, No 23 (Julio 2017), Art. 13, pp. 453-532.

[http://www.politicacriminal.cl/Vol_12/n_23/Vol12N23A13.pdf]

"defensas afirmativas" o "puertos seguros", es decir, normas que declaran que la concurrencia de ciertas circunstancias autorizan excepcionalmente realizar la operación o la excluyen del alcance de la prohibición. Dentro de esas excepciones se encuentra, salvo por el caso de la responsabilidad administrativa por infracción a la $\mathrm{R} 14 \mathrm{e}-3$ SEC en la concepción de la propia SEC, el caso en que la operación consiste en la ejecución de una orden impartida con anterioridad a la posesión de información privilegiada (defensa de la orden previa).

En principio, la relación que existe entre la POP y las defensas afirmativas o puertos seguros es la que existe entre una prohibición y una autorización o exención de la prohibición. Es decir, son relaciones entre normas de comportamiento, o entre una norma de comportamiento y una norma de definición de su frástico. Sin embargo, los dos ejemplos más relevantes de POP del derecho comparado -la R 10b5-1 SEC y el art. 8-1 RAM- son ambiguos en este punto.

La R 10b5-1 SEC declara que la prohibición de fraude es una prohibición de operar "sobre la base de" información privilegiada y luego la define como operación con conocimiento (awareness) de la información privilegiada -o sea, define la POU como POP- y luego declara que una operación no es realizada "sobre la base de" información privilegiada cuando quien actúa se encuentra en alguna de las situaciones descritas como "defensas afirmativas" - R 10b5-1(c) SEC-, de la cuales la primera es la relativa a la orden previa. Esta ecuación "R 10b-5 = POU = [POP - (DDAA)]" admite dos lecturas. Conforme a la primera lectura, la R 10b5-1 SEC habría formulado la R 10b-5 SEC derechamente como una POP y corregido su sobreinclusividad mediante un catálogo exhaustivo de excepciones. Esta es la lectura favorecida por la SEC. Conforme a la segunda lectura, la SEC habría formulado la R 10b-5 SEC como una POU y para hacerla operativa habría establecido una presunción robusta de uso más un catálogo de refutadores potenciales privilegiados de esa presunción. La diferencia entre una y otra lectura se encuentra en la posibilidad de reconocer excepciones no contempladas expresamente por la SEC en la R 10b5-1 como defensas afirmativas o refutadores de la presunción, que es excluida por la primera lectura y admitida por la segunda.

Por su parte, el art. 8-1 RAM consagra los términos con que el ECJ trató en el caso Spector (2009) la formulación de la PO conforme al art. 2-1 DAM. Es decir, se refiere al comportamiento prohibido como operar con información privilegiada y lo define como la acción que realiza una persona que posee información y la utiliza adquiriendo, transmitiendo o cediendo los instrumentos financieros a que esa información se refiere. Tal como lo sabe el derecho europeo desde la versión en idioma inglés de la DAM (2003), el hecho de que la formulación de la PO describa la utilización de la información como la realización de una operación en posesión de ella es ambiguo: esa formulación puede ser leída tanto como una POU -en el sentido de que la formulación especifica el carácter operativo del uso- o como una POP - en el sentido que la utilización no es más que la realización de la operación en posesión de la información-. El preámbulo del RAM considerandos $23^{\circ}, 24^{\circ}$ y $25^{\circ}$ - opta, tal como el ECJ, por una lectura intermedia: entiende que la PO se encuentra formulada como POP pero que esa formulación establece una presunción de uso operativo que es refutable. El art. 9 RAM consagra un catálogo de 
BASCUÑÁN, Antonio. "Posesión, uso y explotación de la información privilegiada como elementos del insider trading en el derecho comparado del mercado de valores".

situaciones que constituyen refutadores privilegiados -el propio RAM les asigna concluyentemente ese carácter-, dentro de las cuales se encuentra la orden previa (art. 9-3a, considerando $25^{\circ}$ del preámbulo). Pero ese catálogo no se entiende como una enumeración taxativa de excepciones: la presunción se entiende "sin perjuicio del derecho de defensa" (considerando $24^{\circ}$ ).

La razón de la apertura del RAM a posibles refutaciones de la presunción que entiende establecida por la POP radica en que la finalidad de la prohibición de operaciones con información privilegiada es evitar que una persona que posee información obtenga una ventaja injusta del beneficio conseguido a partir de dicha información al efectuarse operaciones de mercado sobre la base de dicha información (considerando $23^{\circ}$ ). Por tal razón, sólo las operaciones efectuadas sobre la base de información privilegiada son relevantes para el objeto de la prohibición, que es proteger la integridad de los mercados financieros y aumentar la confianza de los inversionistas, lo que a su vez se basa en la garantía de que estos estarán en igualdad de condiciones y protegidos contra una utilización indebida de información privilegiada (considerando $24^{\circ}$ ).

En resumen, el examen del derecho comparado demuestra que la formulación de la PO consistente con el macro-enfoque acerca del insider trading, es decir, con su concepción como un atentado de peligro abstracto contra el bien jurídico colectivo consistente en la (confianza en la) integridad del mercado de valores es la POU, siempre que se entienda el uso de la información en un sentido amplio. Como esta es una condición cuya satisfacción es difícil de asegurar para la práctica judicial, en el derecho comparado es frecuente la formulación de la PO como POP.

Cuál sea la precisa naturaleza jurídica de la POP -si norma de comportamiento que describe la acción prohibida con mayor alcance debido a la prescindencia del uso como elemento del delito o infracción, o regla de presunción de uso operativo de la información privilegiada- eso es algo controvertido en el derecho comparado. Fuera de duda se encuentra, en todo caso, el reconocimiento de su carácter sobreinclusivo y la necesidad de corregir esa sobreinclusividad mediante el reconocimiento de excepciones (defensas afirmativas, puertos seguros). En el derecho comparado la ejecución de una orden impartida con anterioridad a la posesión de información privilegiada es, indiscutidamente, una de esas excepciones. 
Polít. crim. Vol. 12, № 23 (Julio 2017), Art. 13, pp. 453-532.

[http://www.politicacriminal.cl/Vol_12/n_23/Vol12N23A13.pdf]

\section{BIBLIOGRAFÍA}

ALLEN, Samuel, "The Scope of the Disclosure Duty under SEC Rule 14e-3", Washington \& Lee Law Review n ${ }^{\circ} 38$ (1981), pp. 1054-1073.

BAINBRIDGE, Stephen M., Insider Trading Law and Policy. St. Paul, MN: West Publishing, 2014.

BEGEMEIER, Moritz, "Zur Reichweite der unionsrechtskonformen Auslegung im deutschen Straf- und Strafverfahrensrecht am Beispiel der 'Spector Photo Group'Entscheidung des EuGH”, 2013-5 Onlinezeitschrift für Hochsrichterliche Rechtsprechung zum Strafrecht (2013), pp. 179-186.

BONNEAU, Thierry, Régulation bancaire et financière européenne et internationale. Bruselas: Éditions Bruylant, $2^{\mathrm{a}}$ ed., 2014.

BUNDESANSTALT FÜR FINANZDIENSTLEISTUNGSAUFSICHT, Emittentenleitfaden. 4a ed. 2013. Disponible en:

http://www.bafin.de/SharedDocs/Downloads/DE/Leitfaden/WA/dl_emittentenleitfaden_20 13.pdf? blob=publicationFile \&v=5

CLARKE, Sarah, Insider Dealing. Law and Practice. Oxford: Oxford University Press, 2013.

DAVIS, Harry S. (ed), Insider Trading Law and Compliance. New York: Practicing Law Institute, 2015.

ENTRENA RUIZ, Daniel, El empleo de información privilegiada en el mercado de valores: Un estudio de su régimen administrativo sancionador. Madrid: ThompsonCivitas, 2006.

FERRER BELTRÁN, Jordi, RATTI, Giovanni B., "Validity and Defeasibility in the Legal Domain", 29 Law and Philosophy, pp. 601-626 (2010).

FOFFANI, Luigi, "Tutela penal del Mercado y abuso de información privilegiada: La experiencia italiana", en: ARROYO ZAPATERO, Luis, et al, Hacia un Derecho Penal Económico. Jornadas en Honor del Profesor Klaus Tiedemann. Madrid: Boletín Oficial del Estado, 1995, pp. 501-517.

FREED, Merrill A., SCHRAIBMAN, Steven E., "A Checklist for Officers and Directors Trading in Company Stock, Insights $\mathrm{n}^{\circ} 15$ (2001), pp. 16-20.

FRIED, Jesse M., “Insider Abstention”, Yale Law Journal n 113 (2003), pp. 455-492.

GERHMAN, Philipp, "Das Spector-Urteil des EuGH - Zur Beweislastumkehr beim Insiderhandel Beweislastumkehr beim Insiderhandel", Zeitschrift für Bankrecht und Bankwirtschaft $\mathrm{n}^{\circ} 10-1$ (2010), pp. 48-52.

GIUDICELLI-DELAGE, Genevieve, "El delito de iniciados en el derecho francés", en: ARROYO ZAPATERO, Luis, et al, Hacia un Derecho Penal Económico. Jornadas en Honor del Profesor Klaus Tiedemann. Madrid: Boletín Oficial del Estado, 1995, pp. 401-410.

GÓMEZ INIESTA, Diego José, La utilización abusiva de información privilegiada en el mercado de valores, Madrid: McGraw Hill, 1997.

HANSEN, Jesper Lau, "What Constitutes Insider Dealing?: The Advocate General's opinion in Case 45/08, Spector Photo Group", International and Comparative Corporate Law Journal n ${ }^{\circ} 7$ (2010), pp. 1-13.

, "Insider Dealing Defined: The EU Court's Decision in Spector Photo Group" European Company Law n 7 (2010), pp. 98-105. 
BASCUÑÁN, Antonio. "Posesión, uso y explotación de la información privilegiada como elementos del insider trading en el derecho comparado del mercado de valores".

HAZEN, Thomas Lee, "The New Pragmatism under Section 16b of the Securities Exchange Act", North Carolina Law Review n ${ }^{\circ} 54$ (1975), pp.1-57.

Treatise on the Law of Securities Regulation. St. Paul MN: Thompson/Reuters/West (6a ed.), 2009.

HELLER, Harry, "Chiarella, SEC Rule 14e-3 and Dirks: 'Fairness' versus Economic Theory", The Business Lawyer n 37 (1982), pp. 517-558.

HERNÁNDEZ SAINZ, Esther, "La regulación penal de los abusos de información privilegiada", Actualidad Penal n 9 (1997), pp. 173-216.

, "La prohibición de los abusos de información privilegiada en el derecho del mercado de valores francés", Revista de derecho bancario y bursátil n 71 (1998), pp. 747-814.

, El abuso de información privilegiada en los mercados de valores, Madrid: Civitas, 2007.

HOPT, Klaus J., “The European Insider Dealing Directive” Common Market Law Review $\mathrm{n}^{\circ} 27$ (1990), 51-82.

, "Problemática de la publicidad de la información privilegiada y ad hoc", en: del mismo, Estudios de derecho de sociedades y de mercado de valores. Madrid: Marcial Pons, 2010, pp. 459-522 (publicación original en alemán en 2007).

HORWICH, Allan, "The Origin, Application, Validity, and Potential Misuse of Rule 10b51", The Business Lawyer n ${ }^{\circ} 62$ (2007), pp. 913-954.

HORWICH, Allan, KLEIN, Andrew M. (Schiff Hardin LLP) (2003), A Primer on SEC Rule 10b5-1: Affirmative Defenses For Insider Trading. November 10, 2003. Disponible

en: http://www.schiffhardin.com/Templates/Media/files/archive/binary/kleinprimer_sec10b5-1.pdf

HUANG, Hui, "The Insider Trading 'Possession Versus Use' Debate: An International Analysis", Securities Regulation Law Journal n 33 (2005), pp. 130-155.

IRVING, Robert B., "French Insider Trading Law: A Survey", The University of Miami Inter-American Law Review $\mathrm{n}^{\circ} 22$ (1990), pp. 41-73.

KÖHLER, Diana, "§ 8 - Wertpapierhandelsgesetz", en: Tido Park (ed.), Nomos Kommentar, Kapitalmarktstrafrecht. Baden-Baden: Nomos ( $3^{\mathrm{a}}$ ed.), 2013.

LIVINGSTON, B., HASKELL, E., "Disclose-or-Abstain' Without Restraint: The Supreme Court Misses the Mark on Rule 14e-3 in United States v. O'Hagan", Washington \& Lee Law Review $\mathrm{n}^{\circ} 55$ (1998), pp. 199-246.

LANGEVOORT, Donald D., Insider Trading Regulation, Enforcement \& Prevention. Securities Law Series, Volume 18. Danvers MA: Thompson Reuters/West, 2010.

LASSERRE CAPDEVILLE, Jérôme, "Le délit d'initié: une infraction modelée par les juges", Actualité Juridique Pénal 2011-1 pp. 58-60.

LOSS, Louis, SELIGMAN, Joel, PAREDES, Troy, Fundamentals of Securities Regulation. New York, Wolters Kluwer (6a ed.), 2011.

MARTÍNEZ-BUJÁN PÉREZ, Carlos, "Comentario al art. 285”, en: VIVES ANTÓN, Tomás S. (coord.), Comentarios al Código Penal de 1995. Valencia: Tirant lo Blanch. Volumen 2, 1996, pp. 1382-1392.

Derecho Penal Económico y de la Empresa. Parte Especial. Valencia: Tirant lo Blanch (2a ed.), 2005. 
Polít. crim. Vol. 12, № 23 (Julio 2017), Art. 13, pp. 453-532.

[http://www.politicacriminal.cl/Vol_12/n_23/Vol12N23A13.pdf]

MCGUINNESS, Christine A., "Note: Toward the Unification of European Capital Markets: The EEC's Proposed Directive on Insider Trading", Fordham International Law Journal ${ }^{\circ} 11$ (1987), pp. 432-452.

MOLONEY, Niamh, EU Securities and Finantial Markets Regulation. Oxford: Oxford University Press, 2014.

NAGY, Donna M., "The 'Possession vs. Use' Debate in the Context of Securities Trading by Traditional Insiders: Why Silence Can Never be Golden", University of Cincinnatti Law Review n 67 (1999), pp. 1129-1200.

OPITZ, Peter, "Anmerkung zum EUGH: Nutzung von Insiderinformationen nach der Marktmissbrauchtsrichtlinie - Spector Photo Group NV”, 2010 BKR - Zeitschrift für Bank- und Kapitalmarktrecht 2010, pp. 71-74.

OTTO, Harro, "El abuso de información privilegiada como delito de peligro abstracto", en: Luis Arroyo Zapatero et al, Hacia un Derecho Penal Económico. Jornadas en Honor del Profesor Klaus Tiedemann. Madrid: Boletín Oficial del Estado, 1995, pp. 453468

PANANIS, Panos, § 38. "Wertpapierhandelsgesetz", en: Münchener Kommentar zum Starfgesetzbuch, Tomo 6/1, Nebenstrafrecht II. Múnchen: C.H. Beck, 2010.

PETERSEN, Patricia, "Insider Trading in Frances: beefing up the COB", International Finance Law Review n 9 (1990), pp. 32-36.

PONS-HENRY, Jean Philippe, "Opérations d'inititiés: puisque le manquement se délite, supprimons le délit”, 2011-mars Bulletin Joly Bourse 2011-mars, pp. 211-217.

PRAT RODRIGO, Margarita, El uso ilegal de la información privilegiada en las ofertas públicas de adquisición de acciones (EE.UU. 1933-1988). Bilbao: Ediciones Deusto, 1990.

PRIETO DEL PINO, Ana María, El derecho penal ante el uso de información privilegiada en el mercado de valores. Cizur Menor (Navarra): Thompson-Aranzadi, 2004.

RAYMOND, Michael T., "Validity Challenges to SEC Rile 14e-3", The John Marshall Law Review n 23 (1990), pp. 305-332.

ROLSHOVEN, Max Philipp (2010), “Anmerkung zum EUGH: Nutzung von Insiderinformationen nach der Marktmissbrauchtsrichtlinie - Spector Photo Group NV", BKR - Zeitschrift für Bank- und Kapitalmarktrecht 2010, pp. 74-77.

RYAN, Laura, "Comment: Rule 14e-3's Disclosure-or-Abstain Rule and its Validity Under Section 14(e)", University of Cincinnati Law Review n 60 (1991), pp. 449-493.

SEREDYNSKA, Iwona, Insider Dealing and Criminal Law. Berlin: Springer, 2012.

SETHE, Roth, "Insiderrecht", en: ASSMANN, Hans-Dieter; SCHÜTZE, Rolf A., Handbuch des Kapitalanlagerrechts. München: C.H. Beck, 2015.

STEINBERG, Marc I., Securities Regulation. New York, Law Journal Pres (54ª entrega), 2012.

SWANSON, Carol B., "Insider Trading Madness: Rule 10b5-I and the Death of Scienter", University of Kansas Law Review $\mathrm{n}^{\circ} 52$ (2003), pp. 147-209.

UMHOEFER, Carol, PIÉTRANCOSTA, Alain, "Le Délit d'Initié: Insider Trading in France", Columbia Journal of Transnational Law n 30 (1992), pp. 89-144.

VEGA GUTIÉRREZ, José Zamyr, Mercado de Valores en Derecho Penal. Montevideo: B de f, 2013. 
BASCUÑÁN, Antonio. "Posesión, uso y explotación de la información privilegiada como elementos del insider trading en el derecho comparado del mercado de valores".

VIVES ANTÓN, T.S., ORTS BERENGUER, E., CARBONELL MATEU, J.C., GONZÁleZ CUSSAC, J.L., C. MARTÍNEZ-BUJÁN PÉREZ, C., Derecho Penal Parte Especial, Valencia: Tirant Lo Blanch, 2008.

WANG, William K.S., STEINBERG, Marc I., Insider Trading. Oxford: Oxford University Press (3a ed.), 2010.

WARNER, Kevin E., "Rethinking Trades 'On the Basis Of' Inside Information; Some Interpretations of SEC Rule 10b5-1”, Boston University Law Review n ${ }^{\circ} 83$ (2003), pp. 281-314.

WEHOWSKY, Ralf, "Kommentar-WpHG”, en: ERBS, Georg, KOHLHAAS, Max, AMBS, Friedrich, Strafrechtliche Nebengesetze. Tomo IV. München: C.H. Becks (178a entrega), 2010.

WELCH, Jane, PANNIER, Matthias, BARRACHINO, Eduardo, BERND, Jan, LEDEBOER, Philip, Comparative Implementarion of EU Directives (I) - Insider Dealing and Market Abuse. Londres: The British Institute of International and Comparative Law. City Research Series Nr. 8, 2005. Disponible en: http://www.cityoflondon.gov.uk/business/economic-research-andinformation/research-publications/Documents/20072000/Comparative\%20Implementation\%20of\%20EU\%20Directives\%20I_Insider\%2 0Dealing\%20and\%20Market\%20Abuse.pdf

WOTHERSPOON, Keith, "Insider Dealing - The New Law: Part V of the Criminal Justice Act 1993”, The Modern Law Review n 57 (1994), pp. 419-433.

WRÓBLEWSKI, Jerzy, The Judicial Application of Law, editado por Zenon Bankowski, Dordrecht/Boston: Kluwer, 1992.

ZANOTTI, Roberto, Il nuovo diritto penale dell'economia. Milán: Giuffrè, 2008. 